\title{
1961-1973 Yılları Arasında Bakanlar Kurulu Kararı ile Yasaklanan Yayınlar
}

\author{
Prof. Dr. Mustafa YILMAZ- Dr. Yasemin DOĞANER•
}

\section{ÖZET}

Osmanlı döneminde basın yayın hayatına getirilen denetim, Cumhuriyet'in ilant sonrasında da devam etmiş ve Atatürk sonrası dönemde yine iç ve diş etkenler çerçevesinde sürdürülmüşür. 1961-1973 arası dönemde Demokrat Parti döneminde çıkarılan 5680 sayılı Basın Kanunu aracılığıyla basının denetimi sağlanmış ve özellikle yurt dışından Türkiye'ye getirilen pek çok yayın hakkında yasaklama kararı alınmıştır. Bakanlar Kurulu kararı ile alınan bu yasaklamaların nedenleri dönemin hassasiyetlerine paralel bir seyir takip etmiştir. Incelenen dönemin hassasiyetleri arasında komünist propaganda, etnik temelli propagandalar, Türklï̈̆e hakaret, komşu ülkelerle ilişkilere zarar veren yayınlar, devlet büyükleri aleyhine yaptlan yayınlar ile misyonerlik ve dini propaganda gibi konularl saymak mümkündür.

Anahtar Kelimeler: Basın, Sansür, Yasak Yayın, Demokrat Parti, Bakanlar Kurulu Kararları

\section{ABSTRACT}

The inspection which was introduced to the press in the Otoman era, has continued after the proclamation of the Republic and again in the period aftermath of Atatürk has been kept on along the domestic and foreign circumstances. In the period between 1961-1973 through the Press Law 5680 the inspection of the press was maintained and especially many foreign publications brought to Turkey were prohibited. The motives of those prohibitions concluded by the Cabinet were correlated to the sentiments of the period under study can be considered as; communist propaganda, ethnic-based propaganda, insult to Turkishness, publications destructive to the relationship with neighbouring states, publications against the statesmen and missionary work and religious propaganda.

Key Words: Press, Censorship, Prohibited Publication, Demokrat Party, The Council of Ministers Resolutions

\footnotetext{
• Hacettepe Üniversitesi Atatürk İlkeleri ve İnkılap Tarihi Enstitüsü.
} 
Bakanlar Kurulu kararı ile yasaklanan yayınlar hakkında daha önceki makalelerde kısa basın tarihçesi verildiği için ${ }^{1}$ burada basın tarihçesinin özetleyerek verilmesi düşünülmüştür. Türkiye'de ilk gazete Fransızca olarak İzmir'de yayınlanmış ve bunu aynı şehirde çıkan diğer Fransızca gazeteler takip etmiştir. ${ }^{2}$ Illk Türkçe-Arapça gazete $1828^{\prime}$ 'de Misır Valisi Mehmet Ali Paşa tarafından Vakay-i Mısriyye adıyla çıkarılmıştır. ${ }^{3}$ İlk Türkçe gazete olma özelliğine sahip olan Takvim-i Vekayi'nin resmi bir yayın organıdır. ${ }^{4}$

Takvim-i Vekayi 1840'a kadar basın hayatında yalnızlığını sürdürmüş, bu tarihte Ceride-i Havadis çıkmaya başlamıştır. ${ }^{5}$ Devletin kontrolü altında olan ve hükümeti eleştirmeleri dahi söz konusu olmayan bu gazetelerden sonra özel girişimle Şinasi ve Agah Efendi tarafından 1860 yılında Tercüman-l Ahval çıkarılmıştır. Basında özgürlüklerin dile getirilmesi ve yönetime ilişki eleştiriler basına yönelik düzenlemeleri de beraberinde getirmiştir. 1864 yılında Fransız Basın Yasasından çevrilen Matbuat Nizamnamesi ${ }^{6}$,basın hayatında çeşitliliğin artması üzerine basının üzerindeki denetim de artmıştır. 27 Mart 1867 tarihli Ali Kararnamesi ile İstanbul'da yayınlanan gazeteleri kontrol altına alan ve iktidara gazete kapatma yetkisi veren bir dönem başlamıştır. Yine 1876 Kanunu Esasi'sinin "Matbuat kanun dairesinde serbesttir" hükmüne rağmen kısa süren parlamentoya dayalı hayat sonrası II. Abdülhamit'in istibdat yönetimi ile basın üzerinde daha baskıcı bir dönem başlamıştır?

İkinci Meşrutiyet'in ilanıyla doğan hürriyet atmosferi nedeniyle basında sansür kaldırılmış, dergi ve gazete sayısı ilk üç yılda 500'lere varmıştır. ${ }^{8} \mathrm{Bu}$ özgür ortam 31 Mart ayaklanması sonrasında çıkarılan 1909 Matbuat Kanununa kadar devam etmiştir. ${ }^{9}$ Matbuat Kanununda yapılan değişikliklerle basın üzerinde geniş yetkilere sahip olan hükümet, savaş

' Bu konuda geniş bilgi için bkz. Mustafa Yılmaz, "Cumhuriyet Döneminde Bakanlar Kurulu Kararı İle Yasaklanan Yayınlar (1923-11945), Kebikeç, 1998, Yıl:3, sayı:6; "İsmet İnönü Döneminde Bakanlar Kurulu Kararı İle Yasaklanan Yayınlar (1938-1945), Türk Kültürü Araștırmalarl, Yıl: XXXIV/1-2, Ankara, 1998; "İsmet İnönü Döneminde Bakanlar Kurulu Kararı İle Yasaklanan Yayınlar (1945-1949), Kök Araştırmalar, c.II, Sayı:2, Güz 2000; Mustafa Yılmaz-Yasemin Doğaner "Demokrat Parti Döneminde Bakanlar Kurulu Kararı İle Yasaklanan Yayınlar”, Kebikeç, Yıl: 2006, Sayı: 22, s. 151-204.

${ }^{2}$ Hasan Refik Ertuğ, "Türk Basını Nasıl Doğdu ve Gelişti”, Yeni Türkiye, t ve y yok,s.174.

${ }^{3}$ Orhan Koloğlu, "Osmanlı Basını: İçeriği ve Rejimi”, Tanzimattan Cumhuriyete Türkiye Ansiklopedisi, c.1, İstanbul, İletişim yay., t.y., s.69. s.153.

${ }^{4}$ Hasan Refik Ertuğ, Basin ve Yayın Hareketleri Tarihi, 1.c., İstanbul, Yenilik Bs, 1970,

${ }^{s}$ Geniş bilgi için bkz: Fuat Süreyya Oral, Türk Basin Tarihi, Birinci Kitap, Ankara, Yeni Adım Matb., 1967, s.77-79.

${ }^{6}$ Remzi Balkanlı, Kanunlarımız Bakımından Matbuat Hürriyeti, Ankara, Yeni Matb., 1951, s.23

7 Server Tanilli, Anayasalar ve Siyasal Belgeler, İstanbul, 1962, s.15; Abdülhamit dönemi sansür ve basın hayatı için bkz. N. A. Banoğlu, Basın Tarihimizin Kara ve Ak Günleri, İstanbul, 1960, s.5; Cevdet Kudret, Abdülhamit Döneminde Sansür, İstanbul, 1977.

${ }^{8}$ Kemal Karpat, "The Mass Media", Political Modernizaton in Japan and Turkey, Edit. Robert E. Ward Dakwart A. Rustow, Princeton New Jersey, 1964.

${ }^{9}$ Hasan Refik Ertuğ, "Türkiye'de Basın ve Yayın Mevzuatının Doğuşu ve Gelişimi", Yüzüncü Yll Armağanı, Ankara, Ajans Türk Matb., 1959, s.45-46. 
yıllarında basına sıkı denetim getirmiş, 1909 Matbuat Kanunu 1913 yılında ve 1914 yılında yapılan değişikliklerle devletin iç ve diş güvenliğini bozabilecek nitelikte yayın yapan gazetelerin kapatılması yanında, ülkenin birinci dünya savaşına girmesiyle Sansür Talimatnamesi ${ }^{10}$ yürürlüğe konulmuş ve basın tamamen hükümet tarafından kontrol altına alınmıştır. ${ }^{11}$

Milli mücadele döneminden başlayarak basının işlevinde önemli ölçüde değişiklikler yaşanmıştır. Milli mücadeleyi başlatan Mustafa Kemal Paşa basının kamuoyu üzerindeki etkisini çok iyi bilen bir lider olarak, ${ }^{12}$ kendi fikirlerini hem iç hem de dıș kamuoyuna anlatmada bir kanal olarak görmüş ve bu anlamda basından yararlanmıştır. ${ }^{13}$ Anadolu'daki örgütlenme faaliyetleri sırasında Sivas'ta İrade-i Milliye adıyla bir gazete çıkarılmış ve başlattığı mücadelenin haklılığı Anadolu halkına anlatılmaya çalışılmıştır. Hareketin merkezini Ankara'ya taşıdıktan sonra da bu kez Hakimiyet-i Milliye adıyla yeni bir gazete çıkarılması konusunda güvendiği kimselere talimat vermiş ve o günkü zor koşullarda gazetenin çıkarılması sağlanmıştır. ${ }^{14}$ Yine aynı günlerde Ankara'da Matbuat ve İstihbarat Genel Müdürlüğ̈̈ ve Anadolu Ajansı kurularak iç ve diş haberlerin kamuoyuna sağlıklı bir biçimde duyurulması temin edilmiştir. ${ }^{15}$

Cumhuriyet'in ilanından sonra yönetimin basın üzerindeki etkisi ciddi bir biçimde hissettirilerek, 3 Kasım 1923'de Matbuat Kanununa muadil bir madde ile, Cumhurbaşkanı hakkında basında çıkacak olumsuz görüşlerin üç aydan üç yıla kadar cezalandırılacağı bildirilmiştir. ${ }^{16}$

Şeyh Sait isyanının çıkışında muhalefet basınının rolü olduğu gerekçesiyle 4 Mart 1925 'de çıkarılan Takrir-i Sükun Yasası ile pek çok gazete ve dergi kapatılmıştır. ${ }^{17}$ Ayrıca 3 Mayıs 1925 tarihli kararname ile "Havale-i Şarkiyede İdare-i Örfiye Mıntıkasında Tatbik Edilecek Sansür Talimatnamesi" kabul edilmiştir. ${ }^{18}$

${ }^{10} 16$ sayfalık Sansür Talimatnamesi için bkz. Sansür Talimatnamesi, Matbaayı Askeriye, İstanbul, 1330.

"Server İskit, Türkiye'de Matbuat İdareleri ve Politikaları, Ankara, Başvekalet Yay., 1943, s.200.

${ }_{12}$ M.Nuri İnuğur, "Atatürk ve Basın”, Atatürk Haftası Armağanı 10 Kasım 1991, Ankara, Gen.Kur. ATASE Yay., 1991, s.146-147.

${ }^{13}$ İzzet Öztoprak, Kurtuluş Savaşında Türk Basını, Ankara, 1981

${ }^{14}$ Emin Karaca, Cumhuriyet Olayı, İstanbul, Altın Kitaplar Yay., 1994; Ömer Sami Coşar, Milli Mücadele Basını, İstanbul, Gazeteciler Cemiyeti Yay., 1973, s.122-134.

${ }^{i s}$ Fethi Kardeş, Basın Yayın Genel Müdürlüğü 60 Yılın Hikayesi, Ankara, Başarı Matb., 1980, s.7; Öztoprak, a.g.e, s.41.

${ }^{16} 11$ Recep 327 tarihli Matbuat Kanununun 26. maddesini muaddil layiha-i kanuniye için bkz: B.C.A. Bakanlar Kurulu Kararları Fonu, 030.18.01 .08.39.4

${ }_{17}$ Nurşen Mazıc1, Belgelerle Atatürk Döneminde Muhalefet (1919-1926), İstanbul, Dilmen Yay., 1984, s.153-154.

${ }_{18}$ Mete Tunçay, Türkiye Cumhuriyeti'nde Tek Parti Yönetiminin Kurulması 1923-1931. İstanbul, 1992, s.141; Alpay Kabacalı, Başlangı̨̧tan Günümüze Türkiye'de Basın Sansürü, İstanbul, Gazeteciler Cemiyeti Yay., 1990, s.115. 
1930 yılında yaşanan Serbest Fırka deneyimi sonrasında, 1931 yılında Matbuat Kanunu çıkarılmıștır. ${ }^{19} 1934$ yılında Matbuat ve Umum Müdürlüğü yapılan bir düzenlemeyle daha geniş bir örgütlenmeye gitmiştir. Yine bu bağlamda basının kurumsallaşmasına yönelik faaliyetlerden bir diğeri ise 1935 'te toplanan Birinci Basın Kongresidir. Bu kongrede gündeme gelen Türk Basın Birliği Kanununun çıkarılması ise 1938 yılında gerçekleşmiştir. ${ }^{20}$

İnönü döneminde ise, dönemin hassasiyetleri ve İkinci Dünya Savaş1 bağlamında basın ile ilgili yapılan düzenlemeler Matbuat Umum Müdürlüğü aracılığıyla sıkı bir biçimde kontrol edilmeye devam etmiştir. 1940 tarihinden itibaren uygulamaya konulan ve 1947 yılına kadar sürmüş olan sıkıyönetim tüm basılı yayın ve matbuaları engelleme ve basına sansür koyma yetkisini sıkıyönetim komutanlıklarına vermiştir. İnönü döneminde 1946 yılında Basın Kanununda bir değişiklik yapılmış ve yapılan bir düzenleme ile gazete kapatma yetkisi hükümetten alınmıştır. İnönü'nün 1947 tarihli tarihi beyannamesiyle ülkede demokrasiye geçiş yolunda önemli adımlar atılırken basın da bundan nasibini almıştır. Bilindiği gibi 1950 yılında yapılan seçimlerle iktidar el değiştirecek ve yeni düzenlemeler yapilacaktır.

Demokrat Parti iktidarı ise 5680 sayılı Basın Kanununu 15 Temmuz 1950 'de kabul etmiş ve bu kanunun ilgili maddeleriyle Bakanlar Kurulu kararlarıyla yasaklamalar yapılmıștır. ${ }^{21}$ Incelenen dönemde ise aynı Basın Kanunu geçerli olup, 1961 Anayasası ile gelen özgürlük ortamından basın kanunun etkilenmediği anlaşılmaktadır.

27 Mayıs İhtilalinin ardından Milli Birlik Komitesinin yönetime gelmesi ile başlayan süreçten 1973 yılına kadar olan dönemde Bakanlar Kurulu kararları ile yasaklanan yayınlar bu çalışmanın konusunu oluşturmaktadır. 1923'ten 1960 yılına kadar olan dönem daha önce yayınlanan dört makalede ele alınmış olup, Cumhuriyet Arşivi belgelerinin 1973 yılına kadar olan kısmı okuyucuya açık olduğu için bu çalışma bu yılla sınırlandırılmıştır. Kendisinden önceki dönemlerde olduğu gibi bu dönemin de önceki hassasiyetleri takip eden ve zaman zaman belli konularda artan bir hassasiyetin gözlendiği durumlarla karşılaşılmaktadır. Bu çalışmanın yapılması ile bir ölçüde bu hassasiyetler ortaya koymaya çalışırken, diğer yandan iç ve dış politika konularının kamuoyunu ne kadar etkilediği gözlenmeye çalışılacaktır. Cumhuriyetin ilan edilişinden itibaren Türkiye'nin dış politika konularında gösterdiği yaklaşım tarzı tutarlı bir seyir takip etmektedir. Bu istikrarlı tavır, yayınlar konusunda da kendisini göstermiş ve yasaklamaya neden olan konular belli başlıklar altında toplanmıştır. Dönemin en sık rastlanan yayın yasaklama nedeni Komünizm

${ }^{19} 1931$ yılı Matbuat Kanunu hakkında geniş bilgi için bkz: Basın ve Yayınla Illgili Kanun, Kararname, Nizamname, Talimatname ve Tamimler, Ankara, Başvekalet Matb., 1944, s.8-25.

20 Yeni düzenlemeler ve Matbuat Umum Müdürlüğünün faaliyetleri olan Basın Kongresinin toplanması ile ilgili olarak bkz.. Koç, a.g.e, s. 75-85

${ }^{21} 5680$ sayılı Basın Kanunu için bkz. Resmi Gazete, 24 Temmuz 1950, sayı:7564. 
propagandasıdır. İkinci Dünya Savaşı sonrası Türkiye'nin uluslar arası konjonktürde aldığı vaziyet komünizmi kendi bekası için birincil bir tehdit olarak görmesiyle sonuçlanmış ve sırasıyla Yunan Propagandası, Ermeni Propagandası, Kürtçülük ve Türklüğe hakaret gibi konular yasaklama nedenlerini oluşturmuştur. Bunların dişında dönemin yoğun hassasiyet gösterdiği konulardan biri de müstehcen yayınlardır. Sanırız dünyada bu konuda artan eğilim, Türkiye'de hükümet tarafından dikkatle ele alınmış ve tespit edilen bu tarz yayınların yurda girişi ve dağıtılması yasaklanmıştır. Şimdi sırasıyla konularına göre yasaklanan yayınlardan bahsetmeye çalışalım.

\section{Komünizm Propagandası Nedeniyle Yasaklanan Yayınlar}

Dönemin yayınlarının en çok yasaklanma nedenleri arasında komünizm propagandası gelmektedir. Bu dönemde komünizm propagandası nedeniyle 39 yasaklama kararının alındığı görülmektedir. Bu durumun bir önceki dönemde 47 yasaklama kararının alındığı göz önüne alındığında paralellik gösterdiği söylenebilir. Bu konuda ilk yasaklama kararı 10 Mayıs 1961 tarihinde Histoire Illustree de la Russie (Rusya'nın Resimli Tarihi)* adlı kitaba ilişkindir. ${ }^{22} 21$ Ağustos 1961'de Paris'te Fransızca olarak basılan L'U.R.S.S. adlı kitap ${ }^{23}$, daha sonra sirasiyla Mcmoires de Jacques Casanova de Seingalt, Les Socialistes et L'exercicedu Pouvorr ve Du Kolkhoze Au Kıbboutz adlı kitapların yurda girişi yasaklanmıştır. ${ }^{24}$ Aynı yılın sonlarında bu konuda 4 kararname ile 11 kitabın yasaklandığı anlaşılmaktadır. ${ }^{25}$

1962 yılında Avrahm Yarmolinsky tarafından yazılıp Newyork'ta basılan Road to Revolution (Ihtilale Giden Yol) ve yine aynı yerde basılan Management in Russian Industry and Agriculture (Rusya'da Ziraat ve Endüstri Alanında Sevki İdare) adlı kitapların ${ }^{26}$, yine Leksikografi Enstitüsünün Ansiklopedisi adlı kitabın 3 ve 4. ciltlerini oluşturan Hırvatça iki yayının hukuki, iktisadi, siyasi ve sosyal problemleri ele alarak komünizm rejiminin başka rejimlere karşı üstünlüğünü ileri sürerek menfi propaganda yaptığı için yasaklanması söz konusudur. ${ }^{27}$ Almanya'dan gönderilen Le Ronde ve Zauberreigen adlı iki dergi ile Paris'te basılan $A$ Quor Revent Les Savants Sovietiques adlı kitap komünizm propagandası nedeniyle yasaklanmıştır. Kitap içerik olarak başından sonuna kadar Rusları

* Bakanlar Kurulu Kararı ile yasaklanan yayınların adları kararda geçtiği şekilde aynen aktarılmıştır.

${ }^{22}$ Başbakanlık Cumhuriyet Arşivi, Bakanlar Kurulu Kararları Katalogu 030.18.01. $160.25 .7,1961$

${ }^{23}$ B.C.A $030.18 .01161 .44 .19,1961$.

${ }^{24}$ B.C.A. $030.18 .01 .161 .44 .18,1961$.

${ }_{25}$ Bu kitaplardan bazıları Paris'te basılan La Jeunesse et Le Comunisme, Le Bolchevisme (B.C.A, 030.18.01. 162.46.14), Le Pouvoir Sovietique, Le Development du Capitalisme En Russie (B.C.A, 030.18.01. 162.46.12), Bildiri başlıklı Türkçe broşür(B.C.A. 030.18.01. 162.48.7), Les Mysteres du Kremlin (B.C.A, 030.18.01. 162.49.16), L'U.R.S.S. en 250 Questions, Les Vingt Meilleures (B.C.A, 030.18.01. 161.39.8)'dir.

${ }^{26}$ B.C.A, $030.18 .01 .164 .11 .13,1962$

${ }^{27}$ B.C.A, 030.18.01. 164.14.13, 1962. 
methederek, Sovyetler Birliği'ndeki ilmi çalıșmalar sonucunda elde edilen başarıları ve bunların komünist idare sayesinde meydana geldiğini söylediği için zararlı görüldüğü ifade edilmektedir. ${ }^{28}$

Aynı yılın sonunda daha köklü bir tedbirin alındığı görülmektedir. Sovyet Rusya ile peyk memleketlerde hazırlanan ve memleket için zararlı görülen plak, ses bantları vb. malzemelerin Türkiye'ye sokulması ve dağıtılması 10 Ekim 1962 tarihinde yasaklanmıştır. ${ }^{29} 1963$ yılında bu konuda yalnız bir karar alınmış, bu da Küba'ya ilişkin 5 yayın ve 38 resmin yasaklanması şeklinde olmuştur. ${ }^{30} 1964$ yılında Federal Almanya'da basılan ve burada yaşayan Türk işçilerine dağıtılan Yurdun Sesi adlı dergide, "özel ve yabancı sermaye toprak ağaları, servet sahipleri kötülenerek, memlekette gericilerin faaliyette bulunduğu, rrkçılar, Turancılar, halifeciler, padişahçılar gibi her soydan faşistlerin gericilerin cephesinde yer alarak, bağımsızlık, demokrasi ve barış için savaşanların karşılarına dikildikleri, faşizmin büyük bir tehlike olduğu, pahalılığın nedenleri olarak milli gelirin dağıtılışındaki ve vergilerdeki adaletsizliğin belirtildiği, askeri masraflar, hükümetin ve işverenlerin tutumu vb. konularda yazılan makalelerle komünizm propagandası yapıldığı için" yasaklanması kararlaştırılmıştır. ${ }^{31}$

Suriye'de komünist Kürtler tarafından yayınlanan Perçeyen Bijarte adlı Kürtçe broşür ile Federal Almanya'da teksir edilerek dağıtılan Türk Sesi adlı haftalık bülten 24 Ağustos 1964 tarihinde $^{32}$, Paris'te hazırlanan Nazım Hikmet'e ait 13 şiirden oluşan Plak 29 Kasım 1965 'te ${ }^{33}$, çeşitli plak ve kataloglardan oluşan bazı yayınların da 23 Ocak 1967 'de alınan kararla ${ }^{34}$ yasaklandığ 1 görülmektedir. 22 Mart 1967 'de Amerika'da yayınlanan Quotations Form Chairman Mao Tse Tung adlı kitabın Ihtilalin Özü adlı tercümesi "Komünist Çin Başkanı Mao Tse Tung'un ihtilalin özü hakkındaki düşünce ve fikirlerinden bahsedilerek komünizm propagandası yapıldığı, kitabın İngilizce aslının da yurda sokulması sakıncalı olduğu için" ${ }^{\prime 35}$ ve 30 Mart 1968 tarihinde de Biz İranı Hür ve Bağımsız Yapacağız Hür İran Milli Kurtuluş Cephesi Avrupa Teşkilatı adlı broşür yasaklanmıştır. ${ }^{36}$

Almanya Köln'de faaliyette bulunan Türk Gençliği Kültür Kulübü adlı teşekkülün yayınladığı İş̧i Postast-Emekçilerin Aylık Gazetesi adlı Türkçe gazete 12 Temmuz 1968'de yasaklanmıştır. Yayıncı Fazıl Sağlam tarafından Başbakanlık aleyhine bu nedenle dava açıldığı görülmektedir. ${ }^{37}$ İsveç'te

\footnotetext{
${ }^{28}$ B.C.A, 030.18.01. 165.36.3, 1962.

${ }^{29}$ B.C.A, 030.18.01. 166.46.20, 1962.

${ }^{30}$ B.C.A, $030.18 .01 .169 .17 .5,1963$.

${ }^{31}$ B.C.A, 030.18.01. 176.18.8, 1964

${ }^{32}$ B.C.A, $030.18 .01 \cdot 179.50 .6,1964$

${ }^{33}$ B.C.A, $030.18 .01 .190 .69 .6,1965$

${ }^{34}$ B.C.A. $030.18 .01 .202 .5 .11,1967$.

${ }^{35}$ B.C.A, $030.18 .01,1967$ Ek: $52-31$

${ }^{36}$ B.C.A, 030.18.01.217.23.17, 1968 .

${ }^{37}$ Bu konuda İçişleri ve Dışişleri Bakanlığı ile Danıştay Başkanlığı arasında yazışma yapıldığı ve mahkemeye gazete nüshalarının gönderildiği anlaşılmaktadır. B.C.A, 030.18.01. 222.55.2, 1968 Ek: 52-36.
} 
ikamet eden Güneş Karabuda tarafından hazırlanıp yayınlanan Turkiet En Resehandbook adlı kitap ise yazarının memleketi tanıtırken Nazım, Yaşar Kemal gibi solcu yazarlardan sitayişle söz ettiği için yasaklanmıştır. ${ }^{38} 14$ Ağustos 1968 tarihinde alınan kararla Dialectical Materialism, Democracy and Class Struggle, The Casefor Socialism in the Sixties, Suva Lenin, Mavtsi Tung, Hoşimine, Gifara adlı kitaplar komünizm propagandası nedeniyle yasaklanmıştır. ${ }^{39} 28$ Eylül 1968 'de ise The Continental adlı dergi Vietnam meselesini eleştirerek üç kıtada Amerikan emperyalizminden kurtulmak için halkın çalışmalarının övüldüğü ve bu vesile ile de komünizm propagandası yapıldığı için yasaklanmıştır. ${ }^{40}$

2 Nisan 1969 tarihinde Almanya'da Türkiye aleyhine faaliyet gösteren Almanya Türk Öğrenci Federasyonu tarafından yayınlanan Birlik adlı derginin içeriğinde "Türk emekçilerinin mevcut bilgilerini artırarak politik hayata atılmalarıyla mevcut komprador faşizmi önleyecekleri, Vietnam savaşında ABD'nin haksızlığı, az gelişmiş ülkelerin durumlarını eleştiren solcu kimselerin yazılarına, Nazım Hikmet'in şiirlerine yer verdikleri için ve bazı makalelerin ileride çıkacak nüshalarda devam edeceği anlaşıldığı için" çıkan ve çıkacak bütün nüshalarının yurda sokulması yasaklanmıştır. ${ }^{41}$

Jan Mydal tarafından yazılıp 1966 yılında Amerika'da basılan Report From a Chinese Village adlı kitap, "Çin köylerinde karısı ile birlikte kalıp edindiği izlenimleri eski rejimle yeni rejimi kıyasla anlatarak sonunda komünist rejimi övdüğü için", Lenin tarafından yazılıp Paris'te basılan $L a$ Maladie Infantile Du Communisme adlı kitap ise 1920 yılında Lenin'in İkinci Uluslar arası Komünizm Kongresi arifesinde Avrupa Komünist partilerindeki solcu ilerlemeler ve bu husustaki düşüncelerin sınıf mücadelesini teşvik edici nitelikte olduğu için yasaklanmıştır. ${ }^{42}$

6 Ağustos 1969 tarihinde alınan bir kararla da İngiltere'de ikamet etmekte olup bir İngilizle evli olan Hatice Selma Asworth'un Kardaş adıyla kurduğu ve '30 milyon kardeşim adına mücadeleye başlıyoruz' diyerek faaliyete geçirdiği dernek adına çıkardığı Kardaş adlı dergide hükümeti ve rejimi kötüleyici ifadeler kullandığı, halkı aç, sefil ve cahil gösterip "Türkiye'nin tek kurtuluş yolu sosyalizmdir" başlıklı bir makale ile komünizm propagandası yaptığ 1 için derginin yurda sokulması yasaklanmışır. ${ }^{43}$

Bir diğer karar ise 31 Ekim 1969 tarihinde Batı Berlin'de kurulan Türk Toplumcular Ocağı tarafından yayınlanan Kurtuluş adlı dergi ile ilgilidir. "Mevcut düzeni kötüleyici ve yıkıcı bir ifadeyle Türk milletinin itibarını küçük düşürücü ve zedeleyici nitelikte haber yayınlayan, tamamen komünist

\footnotetext{
${ }^{38}$ B.C.A, 030.18.01. 222.55.3, 1968 Ek: 52-37.

${ }^{39}$ B.C.A, $030.18 .01 .223 .61 .10,1968$.

${ }^{40}$ B.C.A, $030.18 .01 .225 .72 .10,1968$ Ek: $52-40$.

${ }^{41}$ B.C.A, 030.18.01. 232.22.2, 1969 Ek: 52-44. Bkz: Ek:1.

${ }^{42}$ B.C.A, 030.18.01.234.36.13, 1969 Ek: $52-46$.

${ }^{43}$ B.C.A, 030.18.01. 238.56.18, 1969 Ek: 52-47. Bkz: Ek 2.
} 
propagandasını yapan" bu derginin yasaklanması kararlaştırılmıştır. ${ }^{44}$ Derginin kapağında "Zonguldak Şahitlerini Anıyoruz 10 Mart 1965” başlıklı bir ibare ile dergide çoğunlukla Zonguldak'ta bulunan maden işçilerinin ve tarım kesiminde çalışan köylülerin haklarının savunulması ile ilgili yazılar bulunmaktadır. Yasaklanan nüshanın üzerinde "Karadenizli tütüncüler sömürüye karșı birleșiyorlar" bașlıklı yazının içeriğinde bulunan "Ömrünü tütün tarlalarında tüketmiş ihtiyar ninelerimiz, dedelerimiz de bekliyor hala. Bakımsızlıktan ayakları eğrilmiş, ezik bakışlı, boynu bükük, yalın ayak çocuklarımız bekliyorlar. Çıplak çocuklarımız, ezilmiş kadeşlerimiz için, kendi kurtuluşumuz için birleșelim. Bu düzen soygun düzeni, bizi bizden başka düşünen olmaz. Bu düzende tütünü bizden on Liraya alıyorlar. Bizim yılın on iki ayı didinerek yetiştirdiğimiz tütünü kağıda sararak cigara diye 150 Liradan satıyorlar bize. Fakirin dostu olmaz. Fakirler, köylüler, birbirleriyle dost olur ancak. Haksızlığa karşı Tütün Ekicileri Cemiyetinde hakkımızı birlikte alalım." Sözlerinin altının çizilmiş olması dikkat çekicidir. Yine komünizm propagandası nedeniyle 30 Nisan 1970 tarihinde İngiliz Komünist Partisi'nin yayın organı olan Comment adlı dergi "komünizmi övmekle beraber hür devletlerde meydana gelen hadiseleri kendi açılarından değerlendirerek bu rejimin iyi olduğunu kabul ettirmeye çalıştığ ${ }_{1}$ için ve de yurdumuzda bulunan solcu yayınlar da sözü geçen dergilerden aldıkları makaleleri yayınladıkları için" yasaklanmıştır. ${ }^{45}$

11 Ağustos 1971 tarihinde alınan kararla da Batı Almanya'da Türk Kültür Ocağı tarafından yayınlanan Nasırlı Eller adlı aylık işçi gazetesinde "işçi, köylü ve gençlik hareketlerinin yer aldığı, devrimci eylemler adı altında yapılan ve yapılacak olan her türlü hareketin desteklendiği ve bu tür eylemlere işçileri örgütleme çabası gösterildiği, faşizme, emperyalizme şiddetle çatılarak işçi, köylü ve gençliğin Amerika'ya ve onun işbirlikçilerine karşı birleşmeye çağırıldığı, bu arada Kızıl Çin'in sağlık politikasının övüldüğü, köylüleri ve işçiyi orak çekiçli resimlerle gösteren resimlerle, polis ve jandarma aleyhine yazı ve resimlerin yer aldığı, komünizm lehinde ordu aleyhinde yayın yapan bu gazetenin çıkmış ve çıkacak bütün nüshalarının yasaklanması gerektiği” belirtilmektedir ${ }^{46}$

29 Şubat 1972 tarihinde alınan bir kararla da Stokholm, Newyork ve Londra'da basılan 5 yayın ${ }^{47}, 14$ Ağustos 1972'de Tilemann Grimm tarafindan yazılıp 1968, 1969 ve 1970 yıllarında Hamburg'ta Almanca olarak basılan Mao Tse Tung adlı kitabın bütün baskıları ${ }^{48}, 6$ Şubat 1973'te Catherina Gavin tarafindan yazılarak 1971'de İngiltere'de basılan The House of War adlı kitap ${ }^{49}, 27$ Mart 1973 tarihinde Robert C. Tucker tarafından

${ }^{44}$ B.C.A, 030.18.01, 241.74.17, 1969 Ek: 52-49. Bkz: Ek:3.

${ }^{45}$ B.C.A, 030.18.01.249.29.1, $1970 \mathrm{Ek}: 52-51$.

${ }^{46}$ B.C.A. 030.18.01, 1971 Ek: 52-69.

${ }^{47}$ Bunlar Se, Class Struggle in Africa, Neo-Colonialism, Amilcar Cabral, Fidel Castro Speaks, The Great Rebel Che Guevera in Bolivia adlı yayınlardır. B.C.A, 030.18.01. $279.21 .9,1972$

${ }^{48}$ B.C.A, $030.18 .01 .286 .63 .10,1972$.

${ }^{49}$ B.C.A, 030.18.01.299.45.10, 1973. 
yazılıp 1970 yılında Amerika'da basılan The Marxian Revolutionary Idea adlı kitap ${ }^{50}, 26$ Ocak 1973'te Mao Tse Tung (Antology of His Writings), Dialectical Materialism, A Handbook of Marxism adlı kitaplar ${ }^{51}$, 22 Şubat 1973 'te İngilizce ve Fransızca 15 adet yayın ${ }^{52}$, 28 Şubat 1973 'te Batı Berlin'de yayınlanan Halkın Sesi adlı gazete, ${ }^{53} 12$ Haziran 1973'te İsviçre'de basılan Sürekli İhtilal adlı kitap ${ }^{54}, 1972$ yılında Amerika'da basılan China Inside The People's Republic adlı kitap 21 Haziran 1973 tarihinde $^{55}$ ve 1970 yılında Paris'te basılan Guerre De Liberation adlı kitap 23 Temmuz 1973 'te ${ }^{56}$ komünizm propagandası nedeniyle yasaklanmıştır.

\section{Kürtçülük Propagandası Nedeniyle Yasaklanan Yayınlar}

Daha önce de değinildiği gibi Atatürk, İnönü ve Menderes döneminin değişmeyen hassasiyetlerinden olan Kürtçülük konusunda anılan dönemde de aynı oranda hassasiyetin sürdüğü görülmektedir. Bu dönemde bu konuda 14 yasaklama kararı alınmıştır. Bir önceki dönem olarak anılan Menderes döneminde ise bu sayının ilginç bir biçimde aynı olduğu görülmektedir. Ancak şu belirtilmelidir ki, karar sayılarının aynı oluşu aynı miktarda yayına yasaklama getirildiği anlamına gelmemektedir. Bazen bir kararda çok sayıda eserin aynı gerekçe ile yasaklandığı görülmektedir.

23 Mayıs 1961'de Milletlerarası Kürdistan Cemiyeti tarafından Amsterdam'da Almanca olarak basılan Betrifft: Kurden adlı broşür hakkında dönemin ilk yasaklama kararı alınmıştır. ${ }^{57}$ Irak'ta yayınlanan Irakıyün NevaBir Iraklının Niyeti adlı kısmen Arapça, kısmen Kürtçe yazılmış olan derginin Ocak ve Mart 1961 sayılarının Türkiye'ye sokulması Kürtçülük propagandası nedeniyle yasaklanmıştır. ${ }^{58}$ Halep'te basılan El'Şark adlı Kürtçe kitap ile İran'dan gönderilen Firdevs adlı gazetenin bazı nüshaları 10 Temmuz 1962 tarihinde $^{59}$, Paris'te yayınlanan Etudes Anticolonialistes Fiches D'information adlı bülten "Orta şarkta Kürtçülük meselelerini ele alarak Kürtlerin 5 milyon kilometre karelik bir araziye yerleşmiş olduğu, Ağrı'dan Sivas'a, Sivas'tan İskenderun'a kadar bir nüfusa malik oldukları ve nüfusumuzun önemli bir kısmını teşkil ettiklerinden milli bir devlet kurma hakkına sahip oldukları, Birinci Dünya Savaşından sonra önemli miktarda Kürt nüfusun yer değiştirdiği, Şeyh Sait İsyanının 'milli bir Kürt isyanı' olduğu şeyhin bir din adamı olmasının ayaklanmanın mahiyetini değiştirmediği, 1925-1928 yıllarında Doğu Anadolu'da siyasi otoritenin baskı yaptığı, çok sayıda kişinin öldürüldüğü ve bir kısmının batıya sürüldügüü, 27 Mayıs inkılabından sonra Kürtlere karşı durumun

\footnotetext{
S) B.C.A, 030.18.01. 297.27.17, 1973

${ }^{51}$ B.C.A, 030.18.01. 293.4.17, 1973.

52 B.C.A, 030.18.01. 295.18.11, 1973

${ }^{53}$ B.C.A, 030.18.01. 295.19.3, 1973.

${ }^{54}$ B.C.A, 030.18.01.301.51.1, 1973.

${ }^{55}$ B.C.A. 030.18.01. 301.51.6, 1973.

${ }^{56}$ B.C.A, 030.18.01. 303.65.6, 1973.

${ }^{57}$ B.C.A 030.18 .01 . 160.27.2, 1961 .

${ }^{58}$ B.C.A 030.18.01. 161.41.19, 1961.

${ }^{59}$ B.C.A 030.18.01. 165.31.5, 1962.
} 
sertleştirildiği, Diyarbakır, Bitlis, Van, Mardin vilayetlerinde milliyetçi Kürtçü hareketlerin vuku bulduğu, bu hadiselerde yüzlerce kişinin öldüğü, Kürt demokrat partisinin Türkiye'de kuvvetli bulunduğu, solcu ve komünistlerle sıkı işbirliği yaptıkları ileri sürülerek memleketimizin birlik ve bütünlüğünü zedeleyici mahiyette olmasından dolayı" yurda sokulması mahzurlu görülmüştür. ${ }^{60}$

28 Şubat 1964 tarihinde Joyce Blau tarafından yazılıp Brüksel'de yayınlanan Le Probleme Kurde-Essai Sociologique et Historique adlı Fransızca kitabın yasaklanma gerekçesinde "amacının Kürt meselesini aydınlatmak olduğunu belirterek eklediği bir haritada yurdumuzun doğu bölgesini Kürdistan olarak gösterdiği, doğu illerimizde vuku bulan olayların birçok aleyhte isnatlarla süslendiği, Türk makamlarının değişmez eritme siyasetine rağmen Kürtçe alfabe, gazete, plak ve dergilerin gizlice dağıtıldıkları ve bazı aydınlar tarafından desteklenmekte olduğu ileri sürülerek yurdumuzun bütünlügünü zedeleyici ırk ayrımını hedef tutan bu kitabın mahzurlu olduğu" belirtilmektedir. ${ }^{61}$

12 Haziran 1965 tarihinde Derk Kinane tarafından yazılıp 1964 yılında Londra'da basılan The Kurds And Kurdistan adlı kitap ${ }^{62}$, 25 Ocak 1967 tarihinde Kürtçe olarak yayınlanan bilumum matbua, plak, ses bandı ve benzerlerinin yurda sokulması yasaklanmıştır. ${ }^{63} 7$ Şubat 1967 tarihinde General Hasan Arfa tarafından yazılıp Londra'da Oxford University matbaasında basılan The Kurds adlı kitap "içeriğinde Cumhuriyet rejiminin, Türk halkının büyük bir kısmının arzusu hilafına uygulandığı, Şeyh Sait isyanının Allahı tanımayan Türk idaresine karşı yapıldığ 1 ve bu hareketin asıl gayesinin yeni kurulmuş olan Cumhuriyeti yıkıp yerine isyan sırasında Beyrut'ta bulunan Sultan Hamit'in büyük oğlu Mehmet Selim'i getirip hilafeti ve padişahlığı kurmak olduğu, Ağrı isyanının ise milli bir harekete bürünmüş olduğu, Dersim isyanının da hükümetin okul ve yollarla birlikte bölgedeki jandarma karakollarını dağıtmasından ve Kürtlere yapılan tahrik neticesi meydana geldiği, Atatürk'ün ölümünden önce ve sonra alınmış olan tedbirlerin Kürtlerin isyanını zorlaştırdığı belirtildikten sonra hududu geçen aşiret mensuplarının ifadelerinden hürriyet ve bağımsızlık emellerini hiçbir zaman terk etmedikleri, Irak olaylarına yakın ilgi gösterdiklerinin ifade edildiği, ayrıca kitap içerisinde bulunan haritada da Karadeniz bölgesinde Lazlar, Kars ve civarında Azeriler ve Doğu bölgesinde ise Kürtlerin bulunduğu belirtildiği için" kitabın yurda sokulmasının yasaklanması kararlaştırılmıştır. ${ }^{64}$

17 Şubat 1968 tarihinde Memo ve Zeyn adlı Beyrut'ta basılan Arapça kitap $^{65}, 14$ Ağustos 1968 tarihinde merkezi Amsterdam'da bulunan

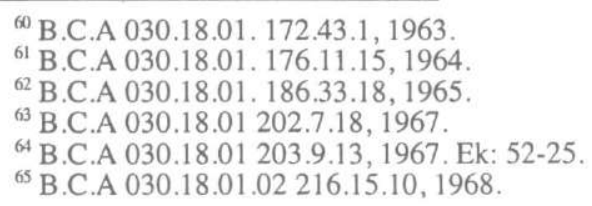


International Society Kurdistan adlı cemiyet tarafından kimliği açıklanmayan ve kuzeyli bir Kürt diye adlandırılan Hemreş Reşo'nun kaleme aldığı Nordwind-Kuzey Rüzgarları adlı Kürtçe-Almanca bir şiir kitabı "mevcut şiirlerde Türkiye'de halen çok sayıda Kürt yaşadı̆̆ı, bunlara yayın hürriyetinin tanınmadığı, fakir bir hayat geçirdikleri, kötü muameleye maruz kaldıklarının ileri sürüldüğü" gerekçesiyle, yine Rene Mauries tarafından yazılıp 1967 yılında Paris'te Fransızca olarak yayınlanan $L e$ Kurdistan Ou La Mort-Kürdistan Veya Ölüm adlı kitap ise "içeriğinde Türklerin Kürt azınlığa daimi baskı yaptığı, ayrıca ön kapak arkasındaki haritada Güneydoğu Anadolu illerimizin Kürdistan toprağı olarak gösterildiği, Türkiye ve komşu ülkelerde yaşayan Kürt azınlıklarının bulundukları devlete karşı bağımsızlık mücadelesi yapmaya davet olunduğu görüldügü için" söz konusu kitabın yasaklanmasına karar verilmiştir. ${ }^{66}$

23 Mayıs 1969 tarihinde alınan bir kararla da Kürtçülük propagandası nedeniyle 2 adet yayının yasaklandığı görülmektedir. Bunlardan ilki Erbendur Haroldsson tarafından yazılıp 1966 yılında Hamburg'ta basılan Land Im Aufstand Kürdistan adlı Almanca kitaptır. "Kitabın içeriğinde milli mücadele yıllarında vatan bütünlüğünü temin için Atatürk'ün yaptığı birçok hareketlerin yerildiği, Kürt isyanından bahsedilirken milletimizin haşin ve barbar olarak gösterildiği, Kürt topraklarının İran, Irak ve Türkler tarafından paylaşıldığı ileri sürülerek bir Kürt devletinin kurulması için bütün Kürtlerin mücadeleye davet edildiği" gerekçesiyle yasaklanmıştır. Emin Sami Alganravi tarafından yazılıp Nisan 1967'de Kahire'de basılan Klssatül Ekrat-Kürtlerin Hikayesi adlı Arapça kitap "içeriğinde Kürtlerin ananeleri, adetleri, dilleri, nüfus miktarı ve yerleştikleri bölgelerden bahsedildiği, içindeki mevcut haritalarda yurdun kuzey kısmının Kürdistan olduğu, Dersim isyanı ve Şeyh Sait harekatına yer verildiği, Cumhurbaşkanı Mustafa Kemal'in Kürtlerin üzerine bir kurt gibi saldırıp Şıh Sait ve avenesiyle birlikte genç yaştaki kadınlarla çocukları hunharca katlettirdiği, kurulan İstiklal Mahkemesinden aldığı kararlarla bütün ilerici Kürt liderlerini kurşuna dizdirdiğinden bahsedildiği, memleketimizin bütünlüğü zedelenmekle beraber Atatürk'e çirkin isnatlarda bulunulduğu için" yasaklanması kararlaştırılmıştır. ${ }^{67}$

8 Mart 1971 tarihinde İsveç'te bulunan Kürdistan Mücadele Cemiyeti tarafından basılan Türkçe Kasırga, Kürtçe Bahez-Kemala Tekeşeren Kurdistan, Almanca Bahez Vereinigung der Kampfer Kurdistans, İngilizce Bahez-Organisation the Fighters of Kürdistan adlı dergiler ${ }^{68}$, 25 Temmuz 1972 tarihinde alınan bir kararla Le Kürdistan Irakien Entite Nationale adlı kitap $^{69}$ son olarak 26 Ocak 1973 tarihinde Les Kurdes Revolution Silencieuse

\footnotetext{
${ }^{66}$ B.C.A $030.18 .01223 .61 .10,1968$.

${ }^{67}$ B.C.A 030.18.01 234.36.13, 1969. Ek: 52-46.

${ }^{68}$ B.C.A $030.18 .01262 .14 .11,1971$.

${ }^{69}$ B.C.A $030.18 .01 .02285 .58 .3,1972$.
} 
adlı Fransızca kitap ${ }^{70}$ yine Kürtçülük propagandası yaptığı gerekçesiyle yasaklanmıştır.

Atatürk sonrası İnönü ve Menderes dönemlerinde pek sık rastlanmayan bir biçimde özellikle Atatürk dönemi ile ilgili Cumhuriyet Türkiye'sinin Atatürk önderliğinde yürüttüğü modern anlamda bir ulus devlet olma çabalarına yönelik eleştirel bakış yanında daha sonra da duyulan ve bugünlerde de yaşanan bir biçimde ayrılıkçı bir tavır görülmektedir.

\section{Rumluk ve Ermenilik Propagandast Nedeniyle Yasaklanan} Yayınlar

Geçmişte ve günümüzde yine devam eden hassasiyetlerden olan Rumluk ve Ermenilik propagandası bu dönemde de yoğun olarak görülmektedir. İncelenen dönemde anılan konularda 33 yasaklama kararının alındığ 1 görülmektedir. Menderes döneminde bu sayı 19 olarak görülmektedir. Dönemin hassasiyetleri arasında Ermenilik ve Rumluk konusunun bu dönemde artan bir seyir takip ettiğini söylemek mümkündür.

Bu konudaki ilk yasaklama kararı Yunanistan'da yayınlanan To Vima adlı gazete hakkında 30 Ocak 1961 tarihinde alınmıştır. ${ }^{71} 27$ Şubat 1961 tarihinde Atina'da Aetos yayınevi tarafından çıkarılan $O$ Kozmoz Pu Peseni O Kocampasis Tu Kastropirgu, O Yero Hronos-İhtiyar Tarih, Lukis Laras ve Bizantines İstories-Bizans Tarihleri adlı kitaplar Yunan propagandası nedeniyle yasaklanmıştır. ${ }^{72} 29$ Haziran 1962 tarihinde Mimi Papadimitrio tarafından yazılıp Yunanistan'da basılan Fediko Sholiko Teatro-Çocuk Mektep Tiyatrosu adlı kitap "içeriğindeki piyes mevzuunun Yunanlıların Türklere karşı isyanlarını, Türklerin Yunanlılara fena muamele ettiklerini anlattığı, Kıbrıs için yazılan piyesin ise Kıbrıs'ın Yunanistan'ın ayrılmaz bir parçası olarak gösterildiği için" yasaklanmış olduğu belirtilmektedir. ${ }^{73}$

28 Aralık 1961 'de Panayiotu İ. Hatzi tarafından yazılan Pağkosmios İstoria adl 1 Yunanca kitapp ${ }^{74}$ ile 1 Şubat 1963 tarihinde Atina Akademisi tarafından 1960 yılında basılan Atina Akademisi Zabitnameleri adlı Yunanca kitabın 35. cildinde “ 'İzmir Kilisesi' adlı eserden bahsederken İzmir vilayetini Yunanlı İzmir olarak gösterdiği, İzmir'in Türkler tarafından istirdadı sırasında birçok şöhretli Episkopos Polikalposun idam edildiği, Hrisostomos'un Türkler tarafından linç edildiği, Mora'daki Tripoliça şehrinde Türkler tarafından katliam yapıldığının ileri sürülerek Türkler aleyhinde asılsız ithamlarda bulunulduğu için" mahzurlu görüldüğü kararın gerekçesinde açıklanmaktadır. ${ }^{75}$

\footnotetext{
${ }^{70}$ B.C.A $030.18 .01 .02293 .4 .17,1973$.

${ }^{71}$ B.C.A 030.18 .01 .02 158.41.1, 1961 .

${ }^{72}$ B.C.A $030.18 .01 .02158 .46 .10,1961$

${ }^{73}$ B.C.A 030.18.01 165.26.14, 1962.

${ }^{74}$ B.C.A 030.18 .01 163.65.13, 1961

${ }^{75}$ B.C.A 030.18 .01 168.6.18, 1963.
} 
21 Kasım 1964 tarihinde Georges Papageorgiou tarafından yazılıp 1964 yılında Atina'da basılan Politiki Morfosis Tom Hristyenikon Ke Müslümanikon Laon-Müslüman ve Hiristiyan Halkının Siyasi Talim ve Terbiyesi adlı Yunanca kitap "içeriğinde Müslümanlık dini aleyhinde ve Ortodoks dini lehinde propaganda yapıldı̆̆ için" yasaklanmıştır. ${ }^{76} 18$ Aralık 1964 tarihinde Yunanistan'da basilan Eikones adlı haftalık Rumca dergi ${ }^{77}$, Kıbris'ta yayınlanan Kıbris Bülteni, Kıbris Cumhuriyeti Halk Istihbarat Ofisi adl bülten $^{78}$, Selanik'te yayınlanan Ellinikos Vorras adl gazete $^{79}$, Yunanistan Kilisesi Havari'nin Hizmetleri başlıkl 1966 yılı cep ve duvar takvimleri ile Günün Bildirisi adlı cep kitab ${ }^{80}, 27$ Ağustos 1966 tarihinde An Expression of Ecumenical-Ekümenik Endişe Açıklaması adlı İngilizce ve Türkçe bildiri ${ }^{81}, 10$ Haziran 1967 tarihinde Atina'da basılan Yi Tu PabtuPontus Toprakları adlı Yunanca kitap ${ }^{82}$, Dimitri Kalumenos tarafından yazılıp 1966 yılında Atina'da İngilizce ve Rumca basılan Hıristiyanlığın Çarmı ha Gerilişi, Barbro Karabuda tarafından yazılıp İsveç’te basılan Öster Om Eufrat-Fıratın Doğusunda, yine aynı yazara ait Rosenkulen-Sanna Berattelser Fran Tukiet-Gültepeleri-Türkiye'den Hakiki Hikayeler adlı kitaplarla Yunanistan'da yayınlanan Nea Estia-Yeni Ocak adlı Rumca dergi ${ }^{83}, 24$ Mart 1968 tarihinde Atina Üniversitesi İlahiyat profesörlerinden P. Trembellas tarafından yazılıp 1967'de Atina'da basılan Dialog adlı kitapta "Patrik Athenagoras ve patrikhanenin sarf ettikleri gayretler ve hizmetler izah edilerek, patrikhanenin zor şartlar altında vazifesini ve tarihi rolünü yaptığı ileri sürülerek, hükümetin laiklik prensiplerini ihlal ettiği ve patrikhaneye baskı yaptığı anlatılmak istendiği için" yasaklanmıştır. ${ }^{84}$

24 Nisan 1968 tarihinde 1968 Yllt Yunan Kilisesi Takviminin yasaklanma gerekçesinde "kitap halinde bulunan takvimde İstanbul'un Türkler tarafından fethinin yıldönümü nedeniyle icra olunacak ayinin metninin yer aldığ 1 ve metnin bir yerinde dua esnasında 'Kraliyet eden şehri (Yani İstanbul'u) elimize teslim et' denildiği, ilerleyen sayfalarda Ortodoks kilisesinin teşkilatına ait bilgiler verildiği ve bu bilgilerin başında Fener patriği Athenagoras'ın makamı için (Konstantinopolisli Athenagoras, Konstantinopolis Yeni Roma Başpiskoposu ve Ekümenik Patrik) denildiği, isim ve makamlar zikredilirken daima Yunancalarının kullanıldığı görüldüğü için" yasaklandığı belirtilmektedir ${ }^{85}$ Bugünlerde tekrar tartışılan bu konu ile ilgili görüldüğgü gibi hassasiyet hep olagelmiştir.

\footnotetext{
${ }^{76}$ B.C.A $030.18 .01181 .71 .11,1964$.

${ }^{77}$ B.C.A $030.18 .01182 .78 .1,1964$.

${ }^{78}$ B.C.A 030.18 .01 195.34.17, 1966

${ }^{79}$ B.C.A 030.18.01 195.34.16, 1966.

${ }^{80}$ B.C.A 030.18 .01 198.59.10, 1966.

${ }^{81}$ B.C.A 030.18.01 198.61.12, 1966.

${ }^{82}$ B.C.A $030.18 .01207 .41 .3,1967$.

${ }^{83}$ B.C.A 030.18.01 209.53.13, 1967.

${ }^{84}$ B.C.A 030.18 .01217 .20 .18 , 1968. Ek: $52-31$

${ }^{85}$ B.C.A 030.18.01. 219.33.11, 1968 Ek: 52-35.
} 
5 Ağustos 1970 tarihinde alınan bir kararla da Atina'da basılan Küçük Resimli Klasik Dergi adlı Rumca dergi "içeriğinde bulunan resimlerin milletler arasında geliştirilmeye çalışılan karşılıklı saygı, dostluk ve insanlık ilişkilerini zedeleyici, Yunan gençliğinde bitmek bilmeyen Türk düşmanlığını bir ideal olarak uyanık tutma çabasını aksettirici nitelikte ve Girit isyanları dolayısıyla Türk vahșet ve barbarlığından bahsedip Yunanlılar hakkında övücü ifadeler kullandığından" yasaklanmıştır. ${ }^{86}$

Son olarak 7 Ağustos 1970 tarihinde "Xenophon Diamond tarafından yazılıp "Amerika Ortodoks Başpiskoposluğuna Pazar okulları için 1969 yılında özel olarak bastırılan ve aleyhimizde faaliyet gösteren Amerika Ortodoks Başpiskoposluğu'nca Pazar Okulları için 1969 yılında özel olarak bastırılan ve aleyhimizde faaliyet gösteren Amerika Ortodoks Başpiskoposu Yakovas Kukuzis tarafından da her Ortodoksun evinde bulunması tavsiye edilen Athenagoras 1 Our Great Patriarch-Büyük Patriğimiz Athenagoras 1 adlı broşürün memleketimizdeki azınlıklara dağıtılmak üzere gönderileceğinin haber alındığı, adı geçen broşürde halen kapalı bulunan ancak bir Türk devlet adamının Rumlar tarafından asılmasından sonra açılacak olan Orta Kapıyı gösterecek şekilde çekilmiş Patrikhane fotoğrafı* ile beraber Ayasofya Camiinin minarelerinin foto montajla kaldırılarak İstanbul'a ait manzaraların altına Constantinople ibaresi yazılarak Bizans'ın başşehri olduğundan bahsedildiği için" yasaklanmasına karar verilmiștir. Yine aynı gün alınan diğer bir kararla da Yunanistan'dan postaya verilerek İstanbul Fener Rum Patrikhanesi adresine gönderilen Yunan Kilisesi Takvimi 1970 adlı kitap "Yunan tarihini canlı tutmak maksadiyla, Yunan kiliselerinden başka Sovyet Rusya ve peyk devletleri Ortodoks kiliseleriyle ruhanilerine ait malumatla birlikte eski yıllardaki milletimiz aleyhinde ibarelerle, baş sayfasında da Bizans bayrağının sembolü çift başlı kartal resminin bulunmasından dolayı" yurda sokulması yasaklanmıştır. ${ }^{87}$

Ermeni propagandası nedeniyle yasaklanan yayınlara bakıldığında bunlarda da ciddi bir yoğunluk gözlenmektedir. Bu konuda ilk yasaklama kararı 31 Mart 1961'de Stepan Şahbaz tarafından yazılıp Beyrut Seven Matbaasında basılan Krikor Zohrap ve Hrimyan Hayrik tarafından yazılan aynı adlı kitap hakkındadır. ${ }^{88} 23$ Mayıs 1961 tarihinde Ermenice Huşarar ile Hayastanyaitz Yegehetzy adl dergiler $^{89} 31$ Mayıs 1961 tarihinde ise Huşmadiyan Tamer Tamarzayl-Tamarza'ya Ait Hatıra Kitabl adlı yayın yasaklanmıştır. ${ }^{90} 1$ Şubat 1963 tarihinde Newyork'ta yayınlanan New Masters Pictorial Encyclopedia adlı ansiklopedide "Erzurum vilayeti hakkında 'Erzurum Sovyet Sosyalist Cumhuriyetinin bir vilayetidir. Eskiden

${ }^{86}$ B.C.A 030.18.01 255.57.17, 1970 Ek:52-55.

- Mora isyanı sırasında Fener Patriğinin de planlayıcılar arasında yer alması sonrası Patrik Gregorios, Sultan II. Mahmut tarafından suçlu bulunmus ve idam edilmiştir. O günden sonra "kin kapısı" olarak adlandıılan Patrikhane girişi kullanılmamıştır.

${ }^{87}$ B.C.A 030.18.01 255.59.14 Ek: 55-56.

${ }^{88}$ B.C. A $030.18 .01159 .15 .20,1961$.

${ }^{89}$ B.C.A $030.18 .01160 .27 .2,1961$

${ }^{9}$ B.C.A 030.18 .01 160.28.17, 1961 . 
Ermenistan'ın bir kısmı idi' denilerek memleketin bütünlüğünü bozucu mahiyet taşıması nedeniyle" yasaklanmıştır. ${ }^{91}$

5 Aralık 1963 tarihinde ise Ardeşeş Biberyan ile Vartan Yeğişeyan tarafından yazılarak Paris'te basılan Batmakirk Adapazar Kağakin-Adapazar Sehrinin Tarih Kitabı adlı Ermenice kitap "bir fermanla Adapazarı şehrinden hicret eden Ermenilerin başından geçenleri hakikatlere uygun olmayan bir şekilde ele alan yazarların Türklere 'frengiden burnu düşük, yalınayak Türk, hayatında beyaz çarşaf, temiz yastık görmemiş, insana yakışır elbise hakkında en ufak bir bilgisi bulunmayan Türk' sevkine memur kumandana 'çetebaşı İbrahim adında ruhsuz hayvanın adamları, insana benzeyen kurt' gibi Türklüğü rencide edecek sözler ile yolda yaya yürüyemeyen bir kadının dipçiklenip öldürüldüğü, iki küçük çocuğun annelerinin cesedi başında açlıktan öldükleri hususunda asıl ve esasa uymayan iddialarla Ermenileri aleyhimize kışkırtıcı pasajlar bulunmasından" dolayı yasaklanmıştır. ${ }^{92} 3$ Mayıs 1966 tarihinde ise Ermeni Meseleleri Arap Kaтиоуи Önünde, 1915 1965 Büyük Katliamı Anma Baskısı, Ermeni Katliamının 50. Yıldönümü İçin Muhtıra, Hayat Senfonisi, Fecaat İzleri adlı Ermeni yazarlar tarafından yazılan ve çeşitli dillerde baskıları olan kitapların toplu halde yasaklandığı görülmektedir. ${ }^{93}$

10 Haziran 1967 'de Kersan Aharunian tarafından yazılan Ağrl Dağından Düşünceler adlı kitap ${ }^{94}, 23$ Ocak 1967'de Ashot Artzurini tarafından kaleme alınan Historia Del Pueblo Armenio adlı İspanyolca kitap $^{95}$, 5 Ağustos 1967 tarihinde ise Hıraç Kılanyan tarafından yazılan Büyük Zulmün Ellinci Yıldönümü adlı kitap yasaklanmıştır. Kitapta "1915 yılında Türklerin aldıkları Ermeni topraklarının geri alınması ve Ermeniler için tazminat istenmesi tavsiye edilmekle beraber içinde bulunan haritalarda doğu illerimizin Ermenistan olarak gösterilmekte olduğundan" yasaklanması kararlaştırılmıştır. ${ }^{96}$

1968 yılı Mart ayında Levon Çormisyan tarafından yazılan ve Beyrut'ta basılan Partiler adlı Ermenice kitap "memleketimizin bir kisminı Ermenistan olarak göstermekle beraber bu topraklar üzerinde bir Ermeni Devleti kurmak için öteden beri yapılan çalışmalardan bahsedildiğinden ve ayrıca aleyhimizde birçok yazılar bulunduğundan" yasaklanmıştır. ${ }^{97}$ Aynı yılın Aralık ayında ise Belleten, Ansekmo, Armenia ve Türk Ermenisi Asker ve Askerliği adlı eserler ${ }^{98}, 23$ Mayıs 1969'da Almanya'da Ludwigsburg şehrinde Karawane adlı kurul tarafından yayınlanan Die Karawane adlı broşür "arkeolojik, kültürel ve tarihi konuları işlerken Ermeniler lehinde

\footnotetext{
${ }^{91}$ B.C.A $030.18 .01168 .6 .18,1963$.

${ }^{92}$ B.C.A $030.18 .01174 .62 .1,1963$.

${ }^{93}$ B.C.A 030.18 .01 155.32.1, 1966.

${ }^{94}$ B.C.A $030.18 .01207 .41 .3,1967$.

${ }^{95}$ B.C.A $030.18 .01202 .5 .11,1967$.

${ }^{96}$ B.C.A 030.18 .01 209.58.17, 1967 Bkz: Ek.4.

${ }^{97}$ B.C.A 030.18 .01 217.20.18, 1968 .

${ }^{98}$ B.C.A $030.18 .01228 .88 .8,1968$.
} 
Türkler aleyhinde propaganda yaptıkları, Türkiye'yi bir ermeni vatanı gibi gösterdikleri için",99, 31 Ekim 1969 tarihinde İran'da bulunan Türk aleyhtarı Ermeni komitelerinin yayın organı olan Alik adlı gazete, "Türklerin 14. asırda zorla Ermenistan'a yerleşerek çok şiddetli bir vahşetle Ermenileri imha ettiklerinden bahsettiği ve özellikle 'Ermeni katliamını' konu olarak ele alıp zaman zaman hazırladıkları makale ve fotoğraflarla memleketimiz aleyhinde sistematik bir şekilde yayın yaptığ yasaklanmasına karar verilmiştir. ${ }^{100}$

29 Mayıs 1970 'de Amerika Boston'da Ermenice olarak yayınlanan The Armenian Weekly adlı gazete ${ }^{101}$, 26 Ocak 1973 tarihinde Cultura Armenia adl 1 İspanyolca kitap ${ }^{102}$ ve 24 Eylül 1973 tarihinde de Katliam-ı Ermeniyan adlı Batı Almanya'da basılan Türkçe gazete ${ }^{103}$ Ermeni propagandası nedeniyle yasaklanmıştır.

\section{Türklï̈̆e Hakaret Nedeniyle Yasaklanan Yayınlar}

Türklüğe hakaret nedeniyle incelenen dönemde 10 yasaklama kararı alındığ ${ }_{1}$ görülmektedir. Bir önceki dönemde yani Menderes döneminde bu konuda alınan karar sayısının 31 olduğu düşünüldüğg̈unde bu konuda alınan karar sayısında ciddi bir azalmanın olduğu görülmektedir. Bu konuda ilk yasaklama kararı 1 Şubat 1963 tarihinde Elia Kazan tarafından yazılıp Newyork'ta basılan America-America adlı İngilizce kitap hakkındadır. Konusu Türkiye'de geçen ve bir film senaryosundan hareketle kitaplaştırılan eserin Basın Yayın Turizm Bakanlığınca yapılan incelemesi sonucunda senaryo olarak üzerinde yapılması tavsiye edilen değişikliklere uyulmadığı gibi bazı sahne ve diyalogların sonradan kitaba eklendiği ve bütün bu ilavelerin Türklüğü rencide edici mahiyette olduğu ve kasten bu yola tevessül edildiği izleniminin uyandığı belirtilerek şunlar ifade edilmektedir. "Türklerin kutsal olarak tanıdığı dini akideleri ve milli duygularını hiçe sayan, daima medarı iftiharı olan Türk askerine hırsızlık, hunharlık ve Türk adliyesine rüşvet ve iltimas şaibesi sürmeye yeltenen ve nihayet misafirperverliğiyle ün salmış bir milleti soyguncu, meyhaneci ve genelevci olarak resmetmek gafletine düşen Elia Kazan'ın bu eserinin yurt dışında bırakacağ müttefikimiz Amerika Birleşik Devletleri Hükümeti nezdinde uyarma ve teşebbüslerde bulunulması da istenmektedir. ${ }^{104}$

25 Eylül 1964 tarihinde Hüsnü Yusuf tarafından yazılıp Arap harfleriyle basılan Devam adlı Türkçe dergi ${ }^{105}$, 4 Eylül 1965 tarihinde A.B. Mısırı tarafından yazılıp Londra'da basılan The Islamic Review-İslam Mecmuass

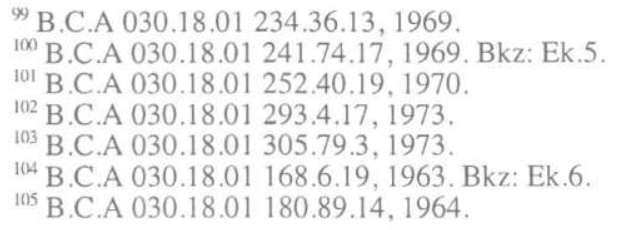


adlı dergi ${ }^{106}$ Türk devletine ve Türklüğe hakaretten dolayı yasaklanmıştır. 22 Eylül 1965 tarihinde Bağdat Siyasal Bilgiler Fakültesinde Profesör Hasan El Atar tarafından yazılan Arap Aleminin Yeni Siyasi Gelişmeleri başlıklı ders notunun yasaklanma gerekçesinde "Abdülhamit dönemindeki muhalefet hayatından ve bu dönemin siyasetinde Yahudilerin etkin olduğundan bahsettikten sonra "Yahudiler istediklerini Abdülhamit'e kabul ettiremeyince büyük kuvvetlerini Masonluk Cemiyetinde topladılar. Bu cemiyet vasitasıyla para sarf ettiler, rüşvet verdiler. Yüksek mevkilere atladılar ve dünya siyaset adamlarını ele geçirmeyi gaye edindiler. Osmanlı Devleti devamınca Yahudiler sureta İslam olmuşlardı. Yahudiliği ilerletmek için içten içe çalışmışlar ve hiçbir zaman Yahudilik emellerinden vazgeçmemiş̧lerdir. Bu kütleye dönmeler denir. Mithat Paşa, Mustafa Kemal ve Talat Paşa bu dönmelerdendir. Mustafa Kemal'in annesi Yahudidir. Osmanlı İmparatorluğu sükut ettikten sonra Mustafa Kemal Türk milliyetçilerinin başına geçerek idareyi eline aldı ve medeniyet iddiasında bulunarak bütün gücü ile İslam alemine, Müslümanlara ve camilere karşı durarak onları yok etmeye çalıştı. Eski Arap harflerini değiştirdi, yeni harfleri getirdi. Yerini tutacak talebeler (siyasiler) yetiştirdi. Arapları sevmeyen bir siyaset takip eden Türkiye, İsrail hükümeti teşekkül edince onu tanıdı" ifadelerine yer verdiği ve müteakip bahislerde Arapların Osmanlı idaresinden kurtuluşlarını zikrettıği için yasaklandığı belirtilmektedir. ${ }^{107}$

28 Eylül 1969 tarihinde alınan bir kararla da İngiltere'de yayınlanan History of The 20 Century adlı dergi "19. yüzyılın ikinci yarısının sonu ve 20. asrın ilk yarısını kapsayacak şekilde Avrupa'nın siyasi durumunu ele aldığı ve bu münasebetle Türkiye'nin hasta adam halindeki zamanına Balkan Devletleri ile olan münasebetleri, Osmanlı İmparatorluğundan ayrılışları ve birer devlet halinde ortaya çıkışlarının anlatıldı ̆̆ı, mecmuanın ön kapağında Abdülhamit'in kafa taslarından yapılmış bir kemerin altından binet ile geçişini ve 198. sayfada da kesik başlar üzerinde, ellerinde ayyıldız işaretli kalkanı ile yürüyen (kana susamış bir barbar) tabiriyle vasıflandırılmış bir Türk'ü canlandıran resimlerin bulunduğunun görüldüğü" ve Türklüğe hakaret içerdiği gerekçesiyle yasaklanmıştır. ${ }^{108}$

9 Aralık 1968 tarihinde Paris'te yayınlanan Connaissance De L'Histoire adlı derginin "163. sayfasında İstanbul kapılarına gelen Rusların 1877'de çok ağır olan Sansitefano Anlaşmasını Türklere imzalattıkları, 1894-1896 yıllarında Türklerin Kürt aşiretlerini Ermenilerin üzerine göndermek suretiyle 250 bin kişiyi katlettirdikleri, 1908'de Jön Türklerin isyanı sırasında Sultan'a sadık askerlerin kendi subaylarını tüfeklerle öldürdükleri, 1912'de Türklerin Sırp köylülerini katlettiklerini ve Bulgar kralı Ferdinand'ın Türk bayrakları üzerinde yürüyüşünü gösteren izahlı resimler bulunduğu için" yasaklanması söz konusudur. ${ }^{109^{\circ}}$

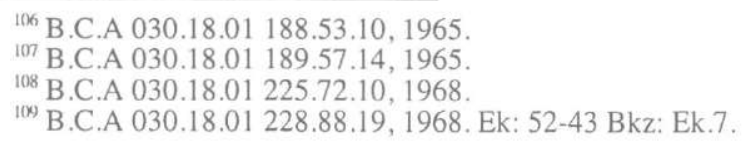


1969 yılında Ian Fleming tarafından yazılan Bons Baisers De Russie adlı kitap hakkında yapılan yazışmalarda Dışişleri Bakanlığı yasaklamayı gerektirecek ciddi bir gerekçe görmezken, İçişleri Bakanlığı'nın kitabın içeriğinde "Türklerin kötü, haşin, görgüsüz, pis, para için her şeyi yapabilen, ürkek, çelimsiz, küçük kişiler, kötü kokulu, küfür işitmeye alışık, demokrasiyi beğenmeyen ve benzeri fena vasıflı olarak gösterildiği için" yasaklanması gerektiği belirtilmektedir. ${ }^{110}$

23 Mayıs 1969 tarihinde alınan bir kararla da Brüksel'de açılan Milletlerarası Salon Des Vacances sergisinin kapanış gününde Bulgar Turizm Bürosu yetkilileri tarafından dağıtılan A La Decouverte Bulgarie adlı broşürde "beş asırlık Türk hakimiyeti sırasında Bulgarlara korkunç derecede mezalim yapıldığı, zulümden kaçan keşişlerin saklandıkları mağaralarda bulunup merhametsizce katledildikleri, şehir ve köyler yağma edilirken yuvalarını terk etmek istemeyen varlıklı ailelerin İslamiyeti kabule ve daha çok vergi ödemeye zorlandıkları, Bulgarların Türklerden daha güzel giyinmesi ve daha güzel silah kullanmasının yasaklandığ 1 , yeniçeri yetiştirmek üzere erkek çocuklarının alındığı ve sultan haremi yapmak için de güzel kızların seçilip padişaha götürüldüğü, ellerinde silahla yakalanan vatanseverlerden hunharca öldürülenlerin sayısının 30 bini bulduğu, Bulgar tarihinin karanlık günlerini yaşadı ̆̆ı ve bu devirde Bulgar dilinin dahi yok edilmek istendiği, Balak isyanı sırasında 5000 kişini imha edildiği ve celladın üzerinde kelleler uçurduğu kütük ve baltanın hala muhafaza edildiğini beyan eden pasajlar bulunduğu için" yasaklanmıştır. ${ }^{11 !}$

30 Nisan 1970 tarihinde alınan kararla K. Sakkadakis adlı Yunanlı öğretmen tarafından yazılan, ders kitapları yayınlama organizasyonu tarafından 1969 yılında Atina'da İlkokul beşinci sınıflar için hazırlanan Çă̆daş Yunan Tarihi adlı kitap "Türklerin cengaver olmasına rağmen cahil oldukları, Yunanistan'ı işgal ettikleri zaman Yunanlılara ait malları ellerinden alıp kendilerini angaryada kullandıkları, erkek çocukları asker yetiştirmek, kız çocukların da cariye olarak satılmak üzere alındığı, canavar Hüseyin Bey'in Girit'i kana buladığı, 370 kadar kadın ve çocuğu Melidoni civarında bir mağarada dumanla boğduğu, Kaşo adasını basarak bütün adalıları kılıçtan geçirdiği ileri sürülerek Türklük aleyhinde iftiralarla dolu olduğu" gerekçesiyle yasaklanmıștır. ${ }^{112}$ Yine aynı tarihte İkinci Dünya Savaşı sonrasında Romanya'dan kaçarak Fransa'ya sı̆̆ınan ve Fransız vatandaşlığına geçen Virgil Georgiu tarafından yazılan ve Fransa'da basılan Dialogues Avec Le Patriarche Athenagoras-Patrik Athenagoras'tn Hayat adlı kitap "Türklerin İstanbul'u işgali sırasında çeşitli vahşiyane davranışlarda bulunulduğu iddia edilerek Türkiye ve Türkler aleyhinde çirkin sözler sarf edildiği, 20. asır Avrupa'sında Haçlı zihniyetinin körüklenmek istendiği, Ayasofya'nın müze haline getirilerek ziyarete

${ }^{110}$ B C.A 03018.01 1969, Ek: 52-29.

III B.C.A 030.18.01 234.36.13, 1969 Ek:52-46.

${ }^{112}$ B.C.A 030.18.01.02 249.29.1, 1970. Ek: 52-51. Bkz: Ek.8. 
açılmasının bir zafer gibi gösterilerek sonunda bu mabedin Ortodokslara teslim edileceğinin ileri sürüldügüu" gibi ifadeler yer aldığ için yasaklanmıştır. Bu konuda son yasaklama kararı 22 Mayıs 1971 tarihinde Dr. Pinhas Ben Nahum tarafindan yazılıp Londra'da basılan ve Pakistan'da Müslüman halkın tepkisine ve taşkınlıklarına sahne olan Turkish Art of Love adlı kitap "milletimizden bahsetmekle beraber çirkin resimlerle ve küçük düşürücü yazılarla dolu olduğu için" yasaklanmıştır. ${ }^{113}$

\section{Müstehcenlik Nedeniyle Yasaklanan Yayınlar}

Dönemin yasaklama gerekçeleri arasında müstehcenlik sayı bakımından ilk sıralarda yer almaktadır.Bu konuda 33 yasaklama kararı alınmıştır. Bir önceki dönem olan Menderes döneminde ayrı bir başlık oluşturacak sayıda yasaklama kararı görülmezken bu dönemde anılan konu ile ilgili pek çok yayının yasaklanmasında sanırız dünyada müstehcen içerikli sayılabilecek yayınların çoğalmasının yanı sıra yurda girişinin kontrol edilemeyişi veya karlı bir sektör oluşu gibi etkenlerin olduğunu söylemek mümkündür.

Bu konuda ilk yasaklama kararı 17 Nisan 1961'de İngiltere'de yayınlanan London Night Life 66 adlı dergi hakkındadır. ${ }^{114} 28$ Nisan'da Foto-Rama adli dergi ${ }^{115}$, daha sonra 26 Temmuz 1961'de Les Nus 13 Çılaklar ile Photo De Nus En Couleurs 50 Renkli Çılaklar Fotoğrafı adlı eserler gelmektedir. ${ }^{116} 3$ Haziran 1961 'de Coctail ve Nakent adlı dergiler ${ }^{117}$, 10 Nisan 1962'de Paris'te yayınlanan Etudes Plastiques adlı dergi tamamen müstehcen mahiyette olduğu için ${ }^{118}, 23$ Haziran 1962'de ise Danimarka ve İsviçre'den gönderilen 4 yayın yine aynı gerekçe ile yasaklanmıştır. ${ }^{119}$ Yine 1 Şubat 1963 tarihinde Foto-Rama adlı İngilizce derginin Aralık 1962 tarihli nüshasında bulunan "bazı resimlerin genç yaştaki çocukların terbiyesi üzerinde kötü tesirler bırakacak şekilde olduğu için” yasaklanmasına karar verilmiştir. ${ }^{120}$

1962 yılında Almanya'nın Bonn şehrinde basılan Magische SchönheitBüyüleyici Güzellik ile Hamburg'da basılan Schönheit die BegeistertGüzelliğin Meftunu adlı albümün yasaklanması söz konusudur. ${ }^{121}$ Norveç’te yayınlanan Helios adlı dergi ile Tidlösa adlı dergiler ve Danimarka'da basılan Sol og Sundhed adlı dergiler ${ }^{122}$, Kaliforniya'da basılmış olan The 1964 Nudist Scene Sundial Calendar adlı İngilizce dergi ${ }^{123}$, Amerika ve

\footnotetext{
${ }^{113}$ B.C.A 030.18.01 02. 266.35.15, 1971 Ek: 52-61

${ }^{114}$ B.C.A $030.18 .01159 .19 .19,1961$.

${ }^{115}$ B.C.A 030.18.01 160.21.15, 1961. Aynı dergi hakkında iki yıl sonra başka bir nüshası için tekrar yasaklama kararının alındığı görülmektedir. Bkz. Dipnot 120.

${ }^{116}$ B.C.A 030.18.01 161.39.8, 1961 .

${ }_{117}^{117}$ B.C.A 030.18.01 160.30.4, 1961.

${ }_{118}$ B.C.A 030.18.01 164.14.12, 1962.

${ }^{119}$ B.C.A $030.18 .01165 .29 .9,1962$.

${ }^{120}$ B.C.A 030.18.01 168.6.18, 1963.

${ }^{121}$ B.C.A 030.18.01 172.43.2,1963.

${ }^{122}$ B.C.A 030.18.01 172.44.11, 1963.

${ }^{123}$ B.C.A 030.18.01 176.13.16, 1964.
} 
Paris'te basılmış olan çeşitli dergiler ${ }^{124}$, Londra'da basılan King adlı dergi içerisinde müstehcen resimler bulunduğu için ${ }^{125}$, Kanada'da basılan 1967 Playboy adl masa takvimi ile Amerika'da yaymlanan 100 Famous Beauties adli derginin 59. sayıs1 ${ }^{126}, 10$ Haziran 1967 tarihinde Amerika'da basılan Playboy adlı dergi ve duvar takvimi ${ }^{127}, 17$ Şubat 1968 tarihinde Roma'da basılmış olan Playmen adlı İtalyanca dergi ${ }^{128}$, 28 Eylül 1968 tarihinde İngiltere'de yayınlanan Penthouse ile Exclusive ve İsviçre'de yayınlanan Private adlı dergiler "tamamen müstehcen mahiyette olduğu ve içerisinde müstehcen resimler bulunduğu için yasaklanmıştır. ${ }^{129}$

9 Aralık 1968 tarihinde Danimarka ve Almanya'dan gönderilen bazı albüm, dergi ve kartpostallar ${ }^{130}$, 6 Ağustos 1968 tarihinde Newyork'ta basılan Popular Photography's Woman 1969 adlı dergi ${ }^{131}$, 30 Nisan 1970 tarihinde Amerika'dan gönderilen Nudis, Jaybird ve Nude Lark adl 1 müstehcen içerikli resimler ${ }^{132}$, 29 Mayıs 1970 tarihinde Fransa'da kaydedilmiş olan Jet'aime...Moi Non Plus adl $1 \mathrm{plak}^{133}$, Almanya'dan gönderildiği anlaşılan beş adet dergi "seksle ilgili yazı ve resimlerden ibaret olduğu için" ve yine 6 Kasım 1970 tarihli Sabah gazetesinde "Müstehcen Mecmualar Yurt İçine Sokuluyor" başlığı ile yayınlanan makale üzerine bu tür yayınların İstanbul Valiliğinden istendiği ve "bunlardan Jasmin adlı derginin yasaklanmasına gerek duyulmadığı ancak Adam, Loi ve Escort adlı dergilerde bulunan resimlerin memlekette bulunan dergilerle kıyaslandığında memleketimizde basılanlardaki çıplak kadın resimlerinin göğüs uçlarının bantla kapatıldığı halde yurt dışında basılanlarda buna riayet edilmediğinden yasaklanması gerektiği" ifade edilmektedir. ${ }^{134}$ Bahsi geçen yayınlarla ilgili olarak Başbakan adına Müsteşar Munis Faik Ozansoy imzası ile İçişleri Bakanlığına gönderilen bir yazıda "mecmuaların yurt içinde basılanlarla mukayesesi yapıldı ğında bunların daha fazla müstehcen sayılabilecek durumda olmadığ 1 ve ayrıca yurt dışından getirilen diğer ciddi mecmualar içerisinde de bu kabil resimlere yer verildiğinin görüldüğü, bu konudaki uygulamaya bir yön vermek amacıyla bir yayının müstehcen olup olmadı̆̆ hususunda başvurulan kriter ile buna karar verilmesinde uygulanan usulün açıklanmasını ve bahsi geçen mecmuaların bir kere de bu yönden incelenerek sonucunun bildirilmesi" istenmektedir. ${ }^{135}$ Daha önceki dönemlere nazaran bu dönemde müstehcenlik gerekçesiyle yasaklama kararlarında ciddi bir artış görülmektedir. Aslında dönemin özelliklerine

\footnotetext{
${ }^{124}$ B.C.A $030.18 .01202 .5 .11,1967$.

${ }^{125}$ B.C.A 030.18.01 203.9.13, 1967. Bkz: Ek.9.

${ }^{126}$ B.C.A $030.18 .01204 .21 .17,1967$.

${ }_{127}$ B.C.A 030.18.01 207.41.3, 1967.

${ }^{128}$ B.C.A $030.18 .01 .02216 .15 .10,1968$.

${ }^{129}$ B.C.A $030.18 .01 .02225 .72 .10,1968$.

${ }^{130}$ B.C.A 030.18.01.02 228.88.18, 1968

${ }^{131}$ B.C.A 030.18.01.02 238.56.18, 1969.

${ }^{132}$ B.C.A $030.18 .01 .02249 .29 .7,1970$.

${ }^{133}$ B.C.A $030.18 .01 .02252 .40 .19,1970$

${ }^{134}$ B.C.A 030.18.01.02 255.57.17, 1970.

${ }^{135}$ Bu konuda bkz. B.C.A 030.18.01.02 Ek: 52-52. Bkz: Ek.10,
} 
bakıldığında 1961 Anayasasıyla artan bir özgürlük ortamı bulunmasına karşın bu konudaki yasaklama kararlarının ters orantılı bir biçimde artması ilginçtir.

7 Ağustos 1970 tarihinde İngiltere, Fransa ve Kanada'dan postaya verilen Adam, Cinema 10-11, Playmates ve Temptation adlı dergiler müstehcen konuları kapsadı̆̆ için $^{136}$, 11 Ağustos 1971 tarihinde Almanya'da basılan Daily Girl Sex Movie Magazine adlı dergi müstehcen resim ve yazıları ihtiva ettiği için, yine Almanya'da yayınlanan St Pauli Nacrihten adlı günlük seks gazetesi tamamen seksle ilgili yazı ve resimlere yer verdiği $\operatorname{için}^{137}$, Almanya'dan gönderilen Einmaleins Fürzwei 111 Lisbesvariatianen adlı kitap $^{138}$, ile Sexy adlı dergi müstehcen resim ve yazılar içerdiği için ${ }^{139}$, Week-End Sex adlı dergi ${ }^{140}, 25$ Temmuz 1972 tarihinde İtalya, Almanya ve İsveç'ten gelen bazı dergiler ${ }^{141}$, 23 Ekim 1972 tarihinde Almanya'da basılan Rebecca-Verlag ile Orgasmus adlı iki yayın ${ }^{142}$, 28 Şubat 1973 tarihinde Amerika'dan gelen bazı kitaplar ${ }^{143}$ yine aynı gün Fransa'dan gönderilen Brigitte S'envoie En L'air ile Flirt 22 adl $^{\text {kitaplar }}{ }^{144}, 17$ Mayıs 1973 tarihinde Amerika'dan gönderilen Pl Magazine, Desafio ve Challange adlı dergiler $^{145}$, 20 Temmuz 1973 tarihinde Almanya'da basılan Smart, Sex-Witz $\operatorname{adl}_{\text {1 yayınlar }}{ }^{146}$ müstehcenlik nedeniyle yasaklanmıştır.

\section{Dini Propaganda Nedeniyle Yasaklanan Yayınlar}

Dini propaganda bu dönemin de hassasiyetleri arasındaki yerini korumaktadır. Bir önceki dönemde bu konuda 7 karar alınmışken anılan dönemde 8 yasaklama kararı alınmıştır. Bu konuda yasaklanan ilk eserler 16 Nisan 1965 tarihinde Seyyid Kutup tarafından yazılan Verasatul İslamiye ile Enis El Haccaci tarafından yazılıp 1952'de Misır'da basılan El İmam adlı Arapça kitaplardır. ${ }^{147} 4$ Eylül 1965 'te ise Şam'da Arapça olarak basılan Bediüzzamn Said En'Nursi Hayatı ve Bazl Eserleri adli risale ${ }^{148}$, 22 Mart 1967 tarihinde Mustafa El Kazvini tarafından yazılan Elnübüvve Vel Enbiya Fi Nazar Ehlil Beyt adlı Arapça kitap "peygamberler hakkında Şia mezhebine göre bilgi verilmekte olduğu ve bazı yerlerde ehli sünnete tarizlerde bulunulduğu, yurttaşlar arasında bölücülük yapacak mahiyette bulunmasından dolayı" ${ }^{149}, 17$ Şubat 1968 tarihinde Elmüneccid adlı Arapça lugat, Íslam Devleti Anayasa Tasarısı adlı Şam'da bulunan Hizbuttahrir adlı

\footnotetext{
${ }^{136}$ B.C.A $030.18 .01 .02255 .59 .14,1970$.

${ }^{137}$ B.C.A $030.18 .01 .02262 .11 .1,1971$

${ }^{138}$ B.C.A 030.18.01.02 266.35.15, 1971 .

${ }^{139}$ B.C.A $030.18 .01 .02266 .36 .8,1971$.

${ }^{140}$ B.C.A $030.18 .01 .02280 .27 .18 .2,1972$.

${ }^{141}$ B.C.A 030.18.01.02 285.58.3, 1972.

${ }^{142}$ B.C.A $030.18 .01 .02289 .81 .7,1972$.

${ }^{143}$ B.C.A $030.18 .01 .02295 .18 .11,1973$.

${ }^{144}$ B.C.A $030.18 .01 .02295 .19 .3,1973$.

${ }^{145}$ B.C.A $030.18 .01 .02299 .39 .5,1973$.

${ }^{146}$ B.C.A 030.18.01.02 302.60.4, 1973.

${ }^{147}$ B.C.A $030.18 .01185 .23 .20,1965$.

${ }^{148}$ B.C.A $030.18 .01188 .53 .9,1965$.

${ }^{149}$ B.C.A 030.18 .01 1967, Ek: 52-31.
} 
cemiyet tarafından basılan broşür ile Müslümanların Ölüm Kalım Meselesi adlı Türkçe broşür dini propaganda nedeniyle yasaklanmıştır. ${ }^{150}$

24 Mart 1968 tarihinde İmam El Gazali tarafından yazılarak Kahire'de basılan El Evfak adlı Arapça kitap "içindeki bazı söz ve şekillerin nüshacılıkta kullanılabileceği için ve örneğin 34. sayfasında yapılacak tılsımın filanın kızının filanın oğluna yanması diye bir muska örneğ bulunduğu, 35. sayfada bir şahsın düşmanlarının üzerine cinlerin musallat edilmesi için yazılacak muska örnekleri ve şekilleri bulunduğu, buna benzer çeşitli muskalar ve sihirbazlık örnekleri kitabın başından sonuna kadar devam ettiği için" yasaklanmıştır. ${ }^{151}$ Bir başka yasaklama kararı 30 Mart 1968 tarihinde 1965 yılında Türk vatandaşlığından çıkarılan Muhsin Alkovani tarafından yazılan Türkçe Almanca yayınlanan İslamın Sesi adlı bülten hakkındadır. "İçindeki Kuran-1 Kerim'e ait yazılarda birçok yanlışlıklar ve tercümesinde bazı hatalı yönler bulunmasından dolayı" yasaklandığı belirtilmektedir. ${ }^{152} 26$ Nisan 1968'de Dünya Müslümanlar Birliği Kongresi dolayısıyla Sait El Sebbağ tarafından çizilip Karaşi'de bastırılan Dünya Müslümanlar Haritası ${ }^{153}$, 5 Ağustos 1970'de Türkiye Milliyetçi ve Mukaddesatçılar İstişari Toplantısında yaptığı konuşma laikliğe aykırı görüldüğü için hakkında takibat yapılmakta olan Yılmaz Gürbüz tarafından kaleme alınan Türkiye'de Laiklik ve Kanunların Zulmü adlı Türkçe kitap "Türk Ceza Kanununun 163. maddesi ile 6187 sayılı kanunun zulüm kanunu olduğundan, Müslüman Türk milletinin rencide edildiğinden, din adamlarının, münevverlerin hapishanelerde süründürüldüklerinden, Türk milletinin inanç, ibadet, yayın, fikir, toplantı, seyahat hürriyetlerinin kısıtlandığından bahsedildiği için" yasaklanmıştır. ${ }^{154}$

\section{Huristiyanlık Propagandası Nedeniyle Yasaklanan Yayınlar}

Bu dönemde Hıristiyanlık propagandası nedeniyle yasaklanan kararların önceki dönemlerle kıyaslandığında büyük bir yoğunluk göstermemektedir. Bir önceki dönemde bu konuda 8 karar alınmışken, anılan dönemde bu sayı 6 olarak görülmektedir. Bunlardan ilki 20 Haziran 1964 tarihinde Belçika'dan Bellefontaine Emile tarafından gönderilen ve milliyetçiliği kötüleyerek Hıristiyan dininin propagandasını yapan Fransızca mektubun yasaklanmasıdır. ${ }^{155} 24$ Ocak 1968 tarihinde merkezi Amerika Birleşik Devletleri'nde bulunan International Bible Students Association adlı Hıristiyan misyoner teşkilatının, merkezi ile Amerika ve diğer ülkelerde bulunan şubeleri tarafından yayınlanan kitap, dergi, broşür ve basılmış mektup gibi yayınların toplu olarak yasaklanması kararlaştııılmıştır. ${ }^{156}$

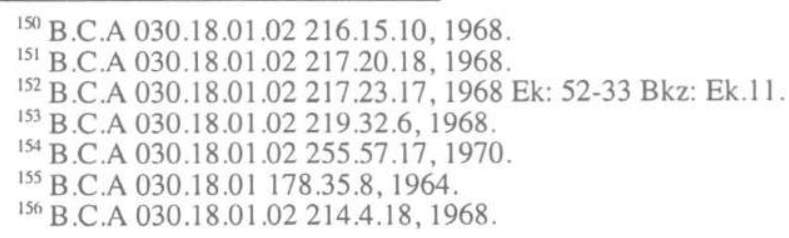


2 Nisan 1969 tarihinde Demetros J. Contantelos tarafından yazılan ve Amerika'da basılan The Greek Orthodox Church adlı İngilizce kitap "Osmanlı İmparatorluğu zamanında Ortodoks kilisesi patriklerinden birçoğunun öldürüldüğü, bir kısmının sürüldüğü, Hıristiyanlara ağır vergiler ödetildiği ve dinlerini değiştirmeye zorlandığı, 'bu uğurda dinini inkar etmeyip canlarını veren şehitleri şükranla anarız' deyip bazı isimler verildiği ve dört asırlık Türk idaresi altında kiliselerin yaşamasının manevi bir mucize olduğu, Türk hükümetlerinin ruhani hayat ve faaliyetler üzerinde yapılan baskılara rağmen Patriklerin bir kale gibi durduğu, bunun sonucu Yunanistan'daki Müslümanların Ortodoks dinine girdiği ileri sürülerek Türkler aleyhinde, Hıristiyanlık lehinde propaganda yaptığı için" yasaklanmıştır. ${ }^{157}$

3 Mayıs 1969 tarihinde Amerika'dan gönderilen Holy Bible ile Fransa'dan gönderilen La Saint Bible adlı Fransızca İnciller ${ }^{158}$, 4 Nisan 1972 tarihinde Atina'da yayınlanmış olan Aksaray-Gelveri Bölgesinde Dini Hayat adl1 Rumca kitap $^{159}$ ve son olarak da 12 Haziran 1973 tarihinde İsviçre'de basılan Hayatın Sirrı ve İncil Hakkındaki Sorularınıza Cevaplar adı Türkçe yayınlar ${ }^{160}$ Hıristiyanlık propagandası gerekçesiyle yasaklanmıştır.

\section{Diğer Konularda Yasaklanan Yayınlar}

Yukarıda anılan kategorilere dahil olmayan, az sayıda ve farkl nedenlerden dolayı hakkında yasaklama kararı alınan yayına da rastlamak mümkündür. İlk olarak 10 Nisan 1962 tarihinde Fuat Satı tarafından derlenip 1957 yılında Şam ve Halep'te basılan Harita Resimleri Defteri adlı kitap "Hatay ilini Suriye sınırları içinde gösterdiği için"|161, aynı gün alınan diğer bir yasaklama kararında Londra'da ateşemiliter olarak görev yapan İrfan Orga ve eşi İngiliz uyruklu Margaret Orga tarafından yazılarak Londra'da basılan Atatürk adlı İngilizce kitap, gerçek olmayan hususlar içerdiği için ve içeriğinde "Atanın özel hayatı üzerinde durularak, zalim, merhametsiz, taşralı, gibi ifadeler kullanmak suretiyle Atatürk'ün aleyhinde bulunduğu için" yasaklanmıştır. ${ }^{162}$

5 Aralık 1963 tarihinde Paris'te basılan Economie et Politique adlı Fransızca dergi "Avrupa'nın Sahte Mücadelesi” başlıklı yazıda "kapitalist müşterek pazarın koyduğu şartlar altında (Milletler Avrupa'sında) bahsetmek yalan söylemek demektir; zira bunun hakiki gayesi hakikati kamufle etmektir, hakikat ise tröstler Avrupa'sıdır, bir hareket formülü gibi bu, halk kitlelerini her milleti demokrasiye götürecek olan monopoller ve tehditlere karşı mücadelęen vazgeçirmeye yarayan bir efsanedir, G. Mollet'nin Avrupa'sı kozmopolit kapitale esir olmuş milletlerin

\footnotetext{
${ }^{157}$ B.C.A $030.18 .01 .02232 .22 .2,1969$.

${ }^{158}$ B.C.A 030.18.01.02 233.30.16, 1969 .

${ }^{159}$ B.C.A 030.18.01.02 280.27.18.2, 1972.

${ }^{160}$ B.C.A 030.18.01.02 301.51.1, 1973.

${ }^{161}$ B.C.A 030.18.01 164.14.2, 1962.

${ }^{162}$ B.C.A $030.18 .01164 .12 .1,1962$
} 
Avrupa'sıdır. Bunun karşısına kapital boyunduruğundan kurtulmuş milletler Avrupa'sını çıkarmak lazımdır. Bu Avrupa'yı tahakkuk ettirmek için Fransız halkına, kendi mukadderatını eline alma ve bankaların iktidar rejimini yıkma imkanını vermekle işe başlamak lazımdır. Avrupa'da yaşayan her millet kendi toprakları üzerindeki monopol hakimiyetine son verdiği an milletler Avrupa'sı bir hayal mahsulü olmaktan çıkacaktır. Bunun haricinde bu sadece De Gaulle'e tamamiyla zit bir siyaset güttüğü halde kendini milli bağımsızlığın müdafii olarak göstermesine yardım eden bir yalandan ibarettir" denildiği ve dergi son sayfasına kadar batı bloku aleyhinde kısımları ihtiva ettiği için yasaklanmıștır. ${ }^{163}$ Daha önce görülen dış politika aleyhine, ülkenin diğer ülkelerle ilişkilerine zarar verici yayınlar gibi başlıklar altında toplanabilecek yasaklamalar bu dönemde yok denecek kadar azdır.

21 Ocak 1964'de Suriye'den gönderilen Türkçe ve Arapça İskenderun Sancağının Kurtarılması adlı beyannameler ${ }^{164}$, 29 Şubat 1964 tarihinde Ali Fuat Başgil tarafından kaleme alınıp İsviçre'de basılan La Revolution Militaire de 1960 en Turquie-Türkiye'de 1960 Askeri Ihtilali adlı Fransızca kitap içerik olarak Türk milletinin mahkum ettiği bir devri methedip Anayasamızda tarifini bulan 27 Mayıs devrimini kötülediği için ${ }^{165}$ ve yine 5 Ağustos 1967 tarihinde Türk parasını koruma kanununa muhalefet suçundan iki yıl ağır hapis ve 26 milyon para cezasına mahkum olan ve Amerika'da yaşayan Ali Muvaffak İpar tarafından Türkçe olarak yazılıp Amerika'da bastırılan Kanun Diye Diye Kanun Tepelendi adlı mektup "27 Mayss ihtilalini kötülemekle beraber Yüksek Adalet Divanınca verilen kararların haksız olduğunu, kendisinin masum olmasına rağmen eziyet gördüğünü, diğer suçlular hakkında af çıktığı halde kendisinin affedilmediğini ileri sürerek, hükümeti kötülemekte olduğu için" yasaklanmıştır. ${ }^{166}$

6 Temmuz 1968 tarihinde Abdullah El Tel tarafından yazılıp Mekke'de basılan İslam ve Huristiyan Alemini Tehdit Eden Milletlerarası Siyonizm adlı kitap $^{167}, 7$ Ağustos 1970 tarihinde İsrail Hükümeti tarafından işgal edilen Arap topraklarını kurtarmak için kurulmuş olan El-Fetih teşkilatınca hazırlanıp çeşitli adreslere gönderilen afiş ve broşürler memleket için zararlı propaganda vasıtası olarak kullanıldığ 1 için yasaklanmıştır. ${ }^{168}$ Son olarak 1969 yılında National Tourist Organization tarafından Şam'da bastırılan Syria Tourist Guide adlı broşür Hatay'ı Suriye sınırları içinde gösteren haritalar içermesi nedeniyle yasaklanmıştır. ${ }^{169}$

Bütün bunların dışında belirtilen dönemde alınan yasaklama kararları arasında karar ekleri bulunmayan ve yalnız yasaklanan yayınların adlarının

${ }^{163}$ B.C.A $030.18 .01 .02174 .62 .8,1963$.

${ }^{164}$ B.C.A 030.18 .01 176.10.1,1964.

${ }^{165}$ B.C.A 030.18 .01 176.13.16, 1964.

${ }^{166}$ B.C.A 030.18.01, 1967. Bkz: Ek.12.

${ }^{167}$ B.C.A $030.18 .01222 .51 .2,1968$.

${ }^{168}$ B.C.A 030.18 .01255 .59 .14 Ek: $52-56$ Bkz : Ek.13.

${ }^{169}$ B.C.A 030.18.01 268.44.9, 1971 . 
yer aldığı ve isimlerinden yukarıdaki gerekçeler içine dahil edilmesi muhtemel konular nedeniyle yasaklandığı anlaşılan çeşitli yayınları kapsayan 29 adet karar bulunmaktadır.

Atatürk ve İnönü dönemlerinde görülen devlet büyüklerine hakaret, Türkçülük, inkılaplara muhalefet, ülke aleyhine yayınlar gibi başlıklar altında toplanabilecek yazılara incelenen dönemde daha az rastlanmaktadır. Sonuçta yeni kurulan genç Cumhuriyetin, yaratılmaya çalışılan ulus devletin ve modern Türkiye Cumhuriyeti'nin tehlike olarak algıladığı iç ve dış politikası için uygun bulmadığı hassasiyet alanlarının giderek, İnönü, Menderes ve incelenen dönemlerde azaldığını söylemek mümkündür. Şüphesiz bunda ülkenin iç dinamikleri kadar içinde yaşanılan dünya ve onun değerleri ile bunların Türkiye'ye yansımalarının etkisi vardır.

Diğer yandan incelenen dönemde de devam eden ve 1990'lı yıllara kadar hep devam edecek olan Komünizm tehlikesi yanında, Rumluk ve özellikle de Ermenilik konusu ile ilgili Türkiye'nin bugün ciddi olarak karşılaştığı ayrılıkçı hareket olarak Kürtçülük hep bu konular arasında yer almaya devam etmiştir. Bunun yanı sıra farklı olarak bu dönemin dikkat çeken yasaklama nedenleri arasına müstehcenlik gibi konuların da girdiğini söylemek mümkündür. 


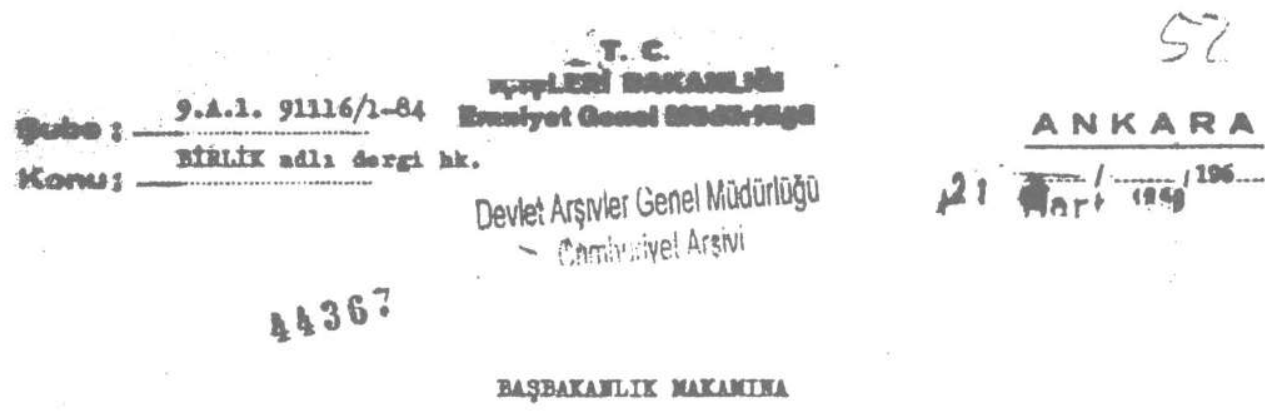

Alanya 33 Rostfacht 778 adroinde kurulan vo Yurdumus

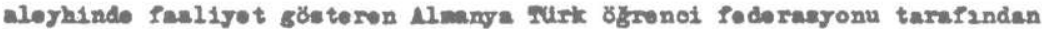

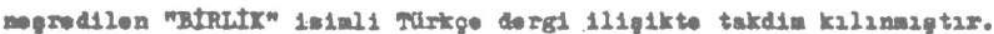

windereotinda Turk omkgtlerin bilglerint artirarak politik

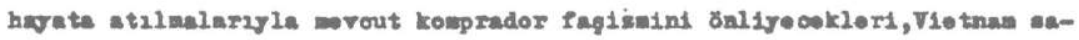

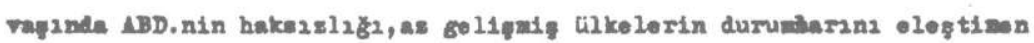

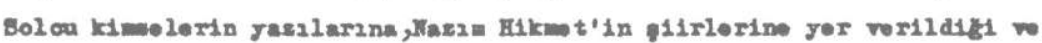

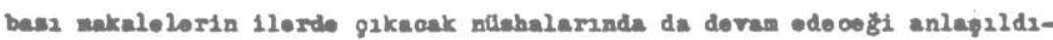

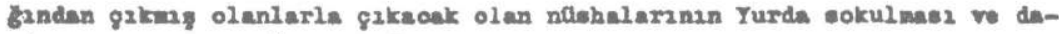

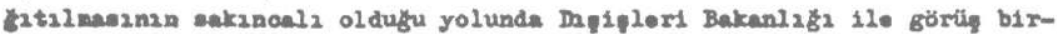

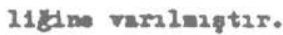

5680 sag2l1 Kanunun 31. Maddegine gorn Bakaniar Kurulundan yasak

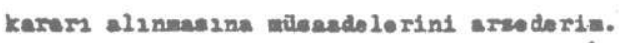

Un:
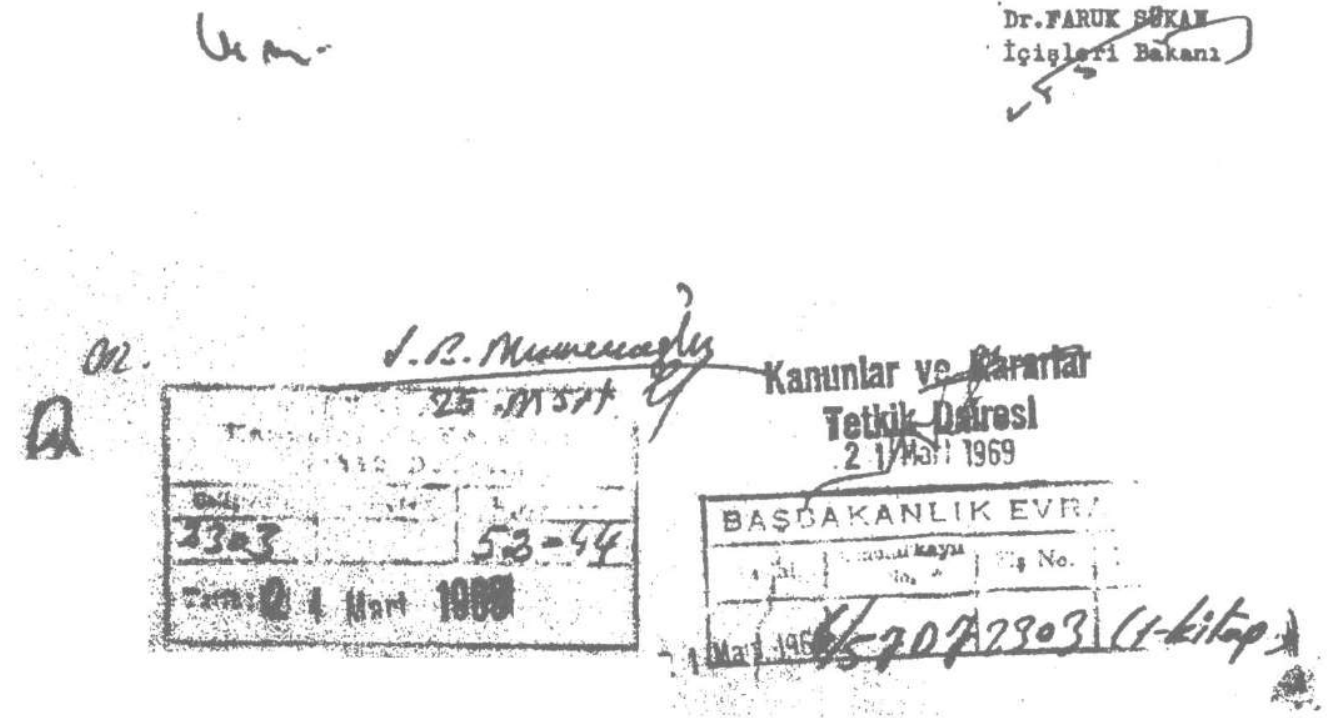


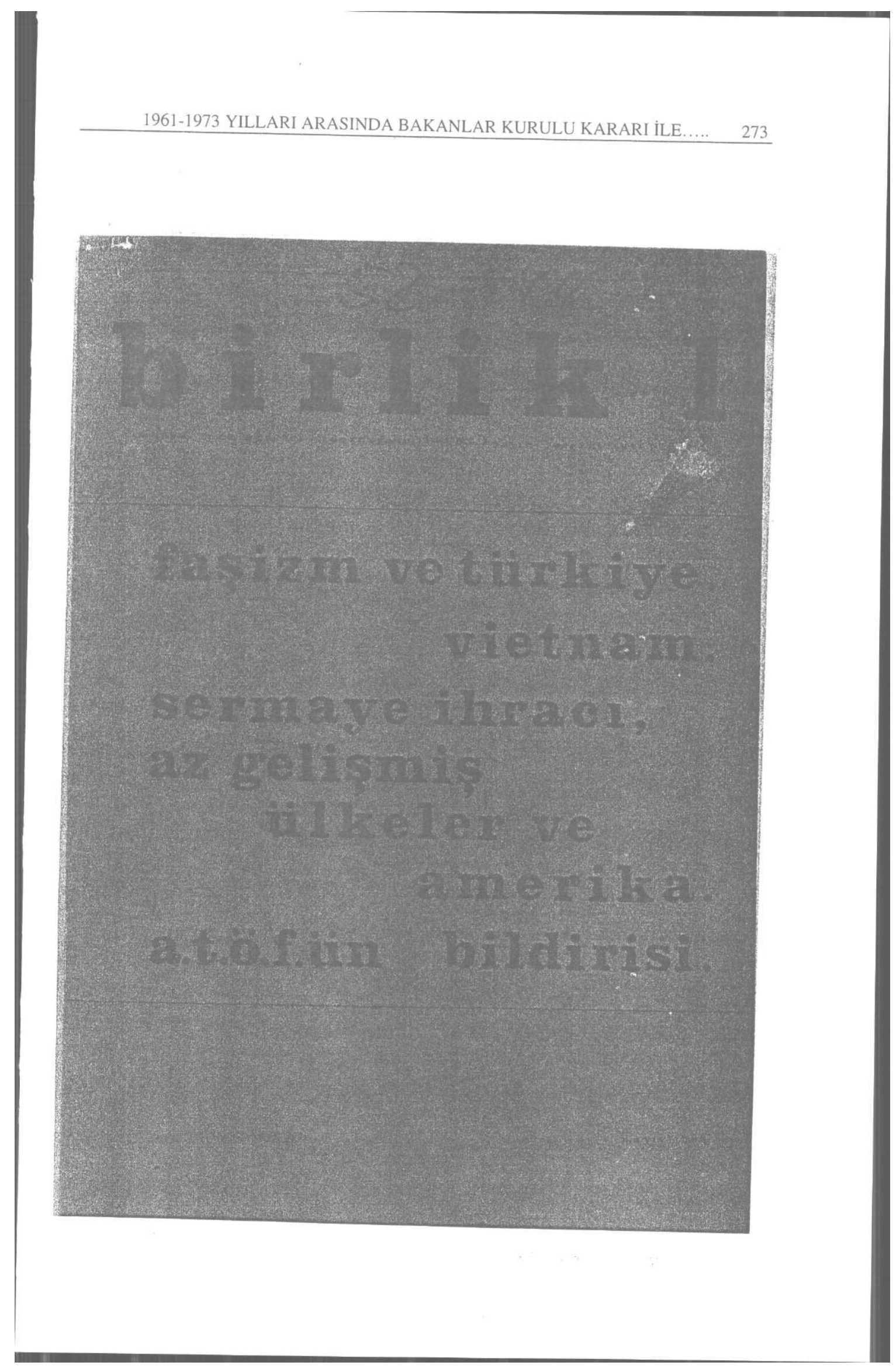




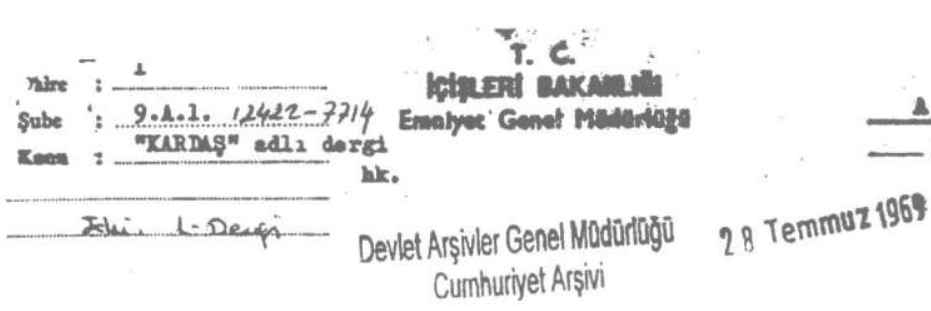

$11 \div 496$

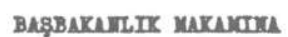

Vatandaglaramadan olup 1964 tarihind Ingilis uyruklu mithondis ROMLD BARRTS ASWORTH 110 evlenexok halon egi 1.0 birlikto

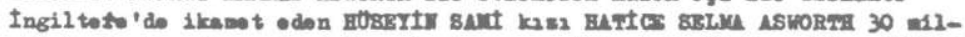

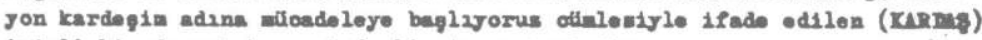
1einli bir dornek kurarak faeliye to girmigtir.

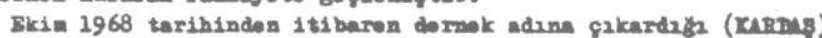

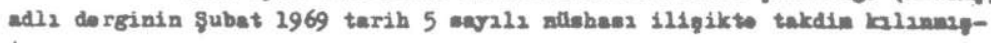
t2x.

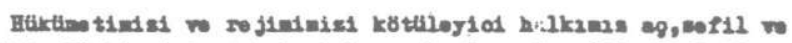

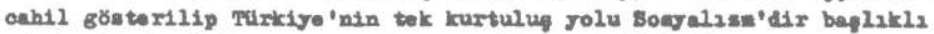

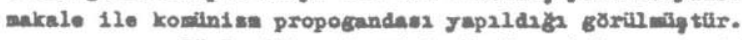

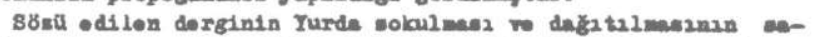

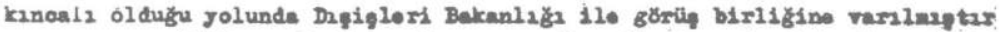

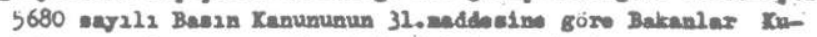

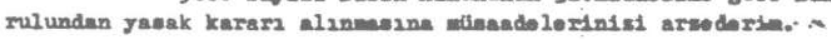

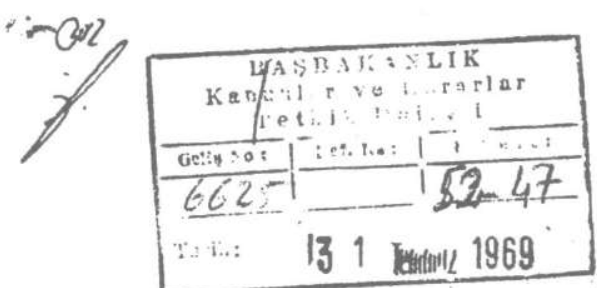

Dr.Yitive gover Igtsy if buxum 15
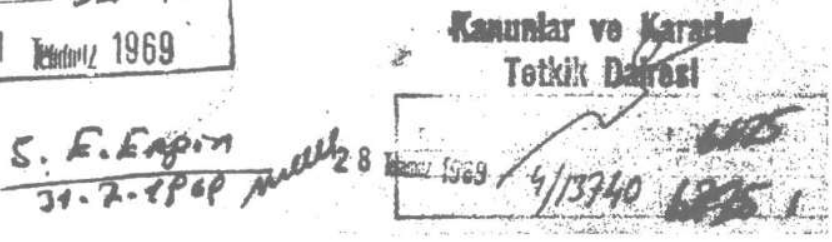


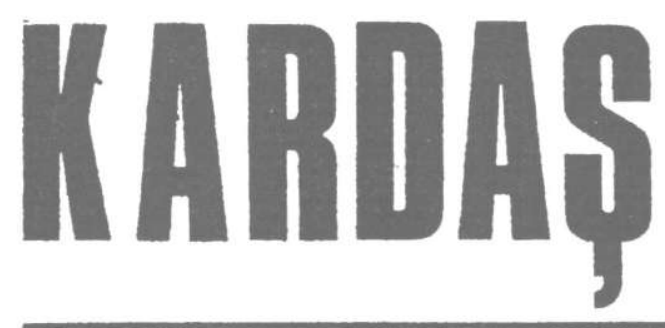

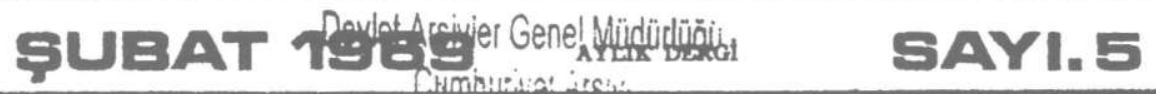

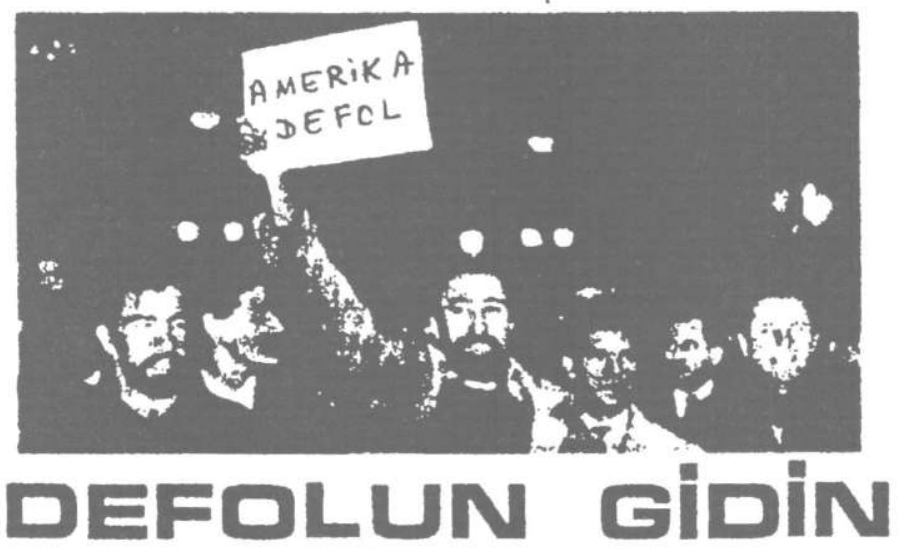

Ameriban emperyalistleri, 6'cl fllo ve vatan ortimcek aga gibi armis olan Amerikan tisleri, yarchm misyoniari, defolun di yorus sitze, defolun gditin.

Amerilcan emperyaliotleriyle is birllğ edenler, yabanci somUirlkellerin yerll ortaklari, Morrieon firman colmezleri, defolun dil yoruz siee, dofolun gditin.

Turtyeyl askeri ve ekconomik ythden Ame rikamn boyunduruguma nolmus vatan aticila$\mathrm{r1}$, defolum dityorus sive, defolun cidin.

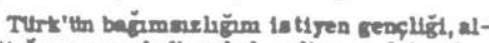
dattişms rene halk evlach pollse coplatan, loarde gin burdefi vurmasina ortam hasurluyan namertler, defolun di yorue aize, defolun glitin.

Emperyalizme, Insamn inman somtrmosine

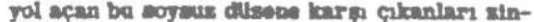
danlarch cttritten fagl at efendiler, defolun diyorux ative, defolun gidin.

Babelarimis, Btrinci Kurtulug Bavapinch,

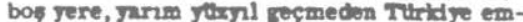

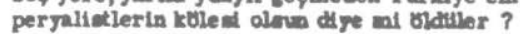

Onlarin btze biraktig başomes Turldye bugth Ameriban emperyallutlerinin ayaklan alisinda ctg̈ronmektedir.

Idincd Kurtulus Savasim verme siras bizlerdedir. Turitye yent bastan bağimazliogim elde edene, emperjaliatleri ve camak yalaycilarin vatandan sturene kadar savagmala giz. Bizim avagimin Ianci Xurtulus savapin ka zanmakla bitmi yocek. Agalar1, kompradorlar1, Turk hallani 60 milirenleri yok edene dek gartlaklaqacagiz.

Bu Ulual Kurtulng Bavagnn verirken, Ife-1 snifimuzi bilimeol Bonylizm yolunda egtmek; kbyllumtirltm ağalarn elinden kurtarilmasan saglamak ve bu yoldh gerçek devrimleri yapmanin esas amacimiz olchugunu bir an dahi unutmi yacaine.

Yagasin gerçelten bağmoux, insanlarumn Insanlar tarahinche sumulullimedis, demolera tut Turkdye.

KARDAS DERNTĞi. 


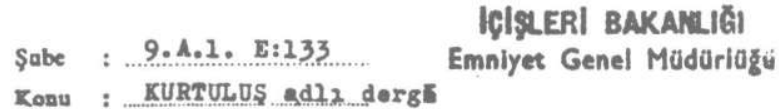

猎.

Bai:1-Dorgi

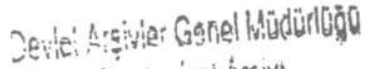

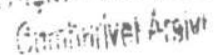

16.1975

BAŞBAKANLIK MAKAMINA

Batz Borlin'de kurulan Tïrk Toplumeular Ocă̌z tarafından

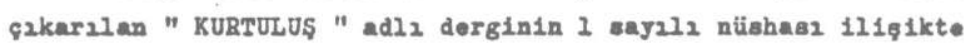
takdin kzlınmagtzr.

Mercut Kanunl dïzeni kötilleyicl ve yakıcı bir ifadeyle Tirk milletinin 1tibarınz kịgük düg̨iribioü ve zedeleyici bir nite11kte haber yayznlayan, tamamon Kowïnist rejimin propogandasini yapan bu derginin Yurda sokulmasinin ve dağitılmasinin sakıncalı olduğ yolunda D2sigleri Bakanliğ 1le görüs birliğine varzlmegtır. 5680 say2l2 Baszn Kanununun 31.Maddesine göre Bakanlar Kurulundan yasak kararz al 2 masang mìsandelerinizi arzederia.
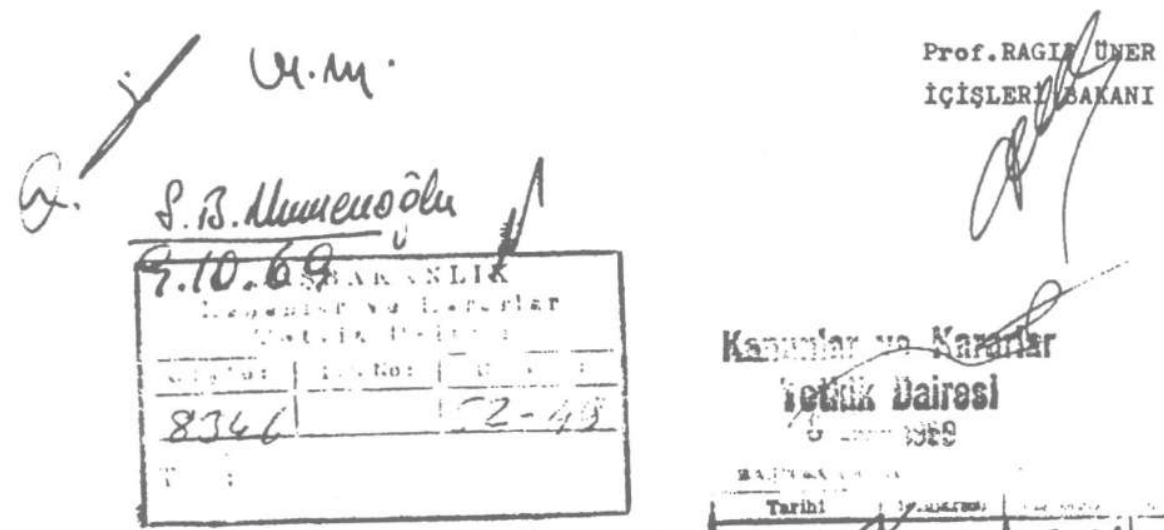

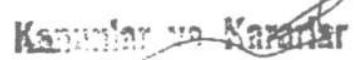
ietivi dairesl

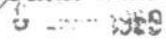

ant -8 Ekim : isig 


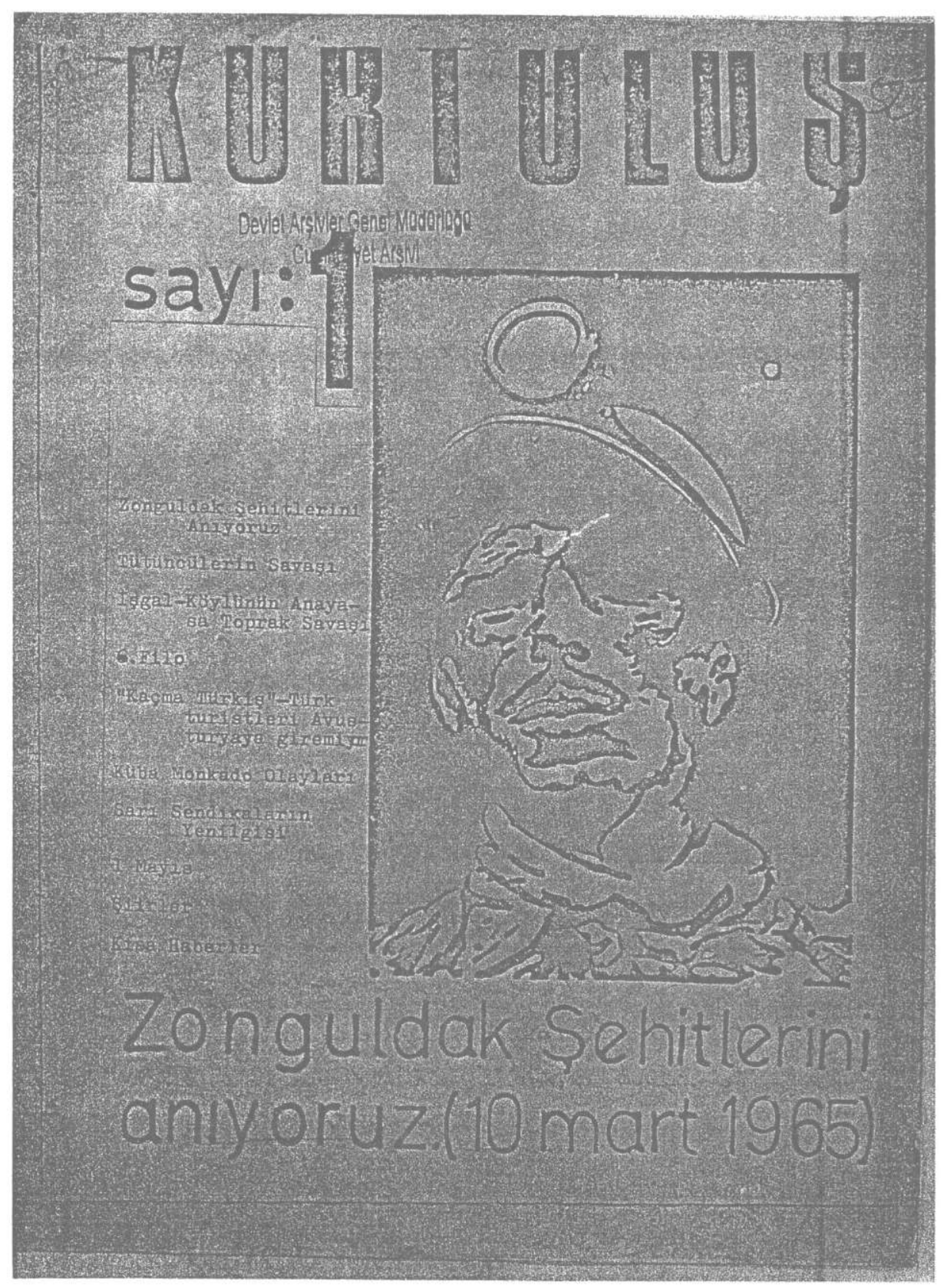




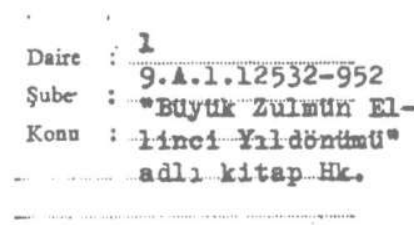

Exi:

1.K1tap

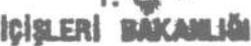

Emnlyet Genel Madirlaz̧o

Devlet Arsiviler Genel Müdürtugo Ruminivast Arsirl

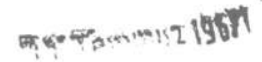

$$
8244^{2}
$$

BA ŞBAKANLIX MUKAXINA

Hirac Kilanyan tarafinan yaz2lip, 1965 y2ll faken-

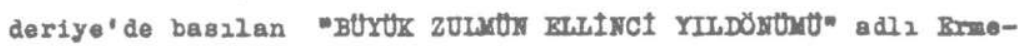
nice k1tap, 1lisikte takdia kilinmistır.

1905 yzlinde Turklerin aldiklari Erment topraklarman geri alınmas ve bldurdukleri emen1ler 1çin tasminat 1atenmea1 tavsiye edilmokłe beraber igersinde bulunan haritalarde Dogu 1llerim1z Ermenistan olsak grategilmekte oldugundan ruxda

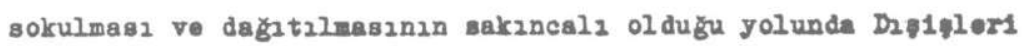

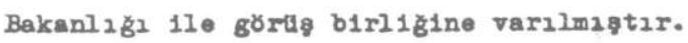

5680 say 212 Kanunun 31. aaddes1ne grre Bakanlar Xurulundan Yasak Karari al nnmasna malsadelerin1 arzederim.

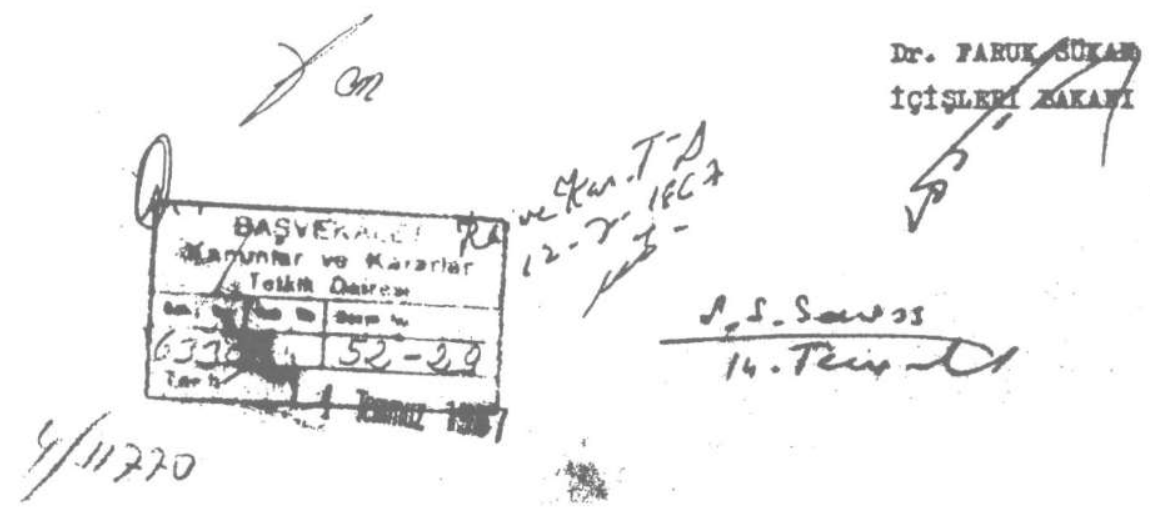




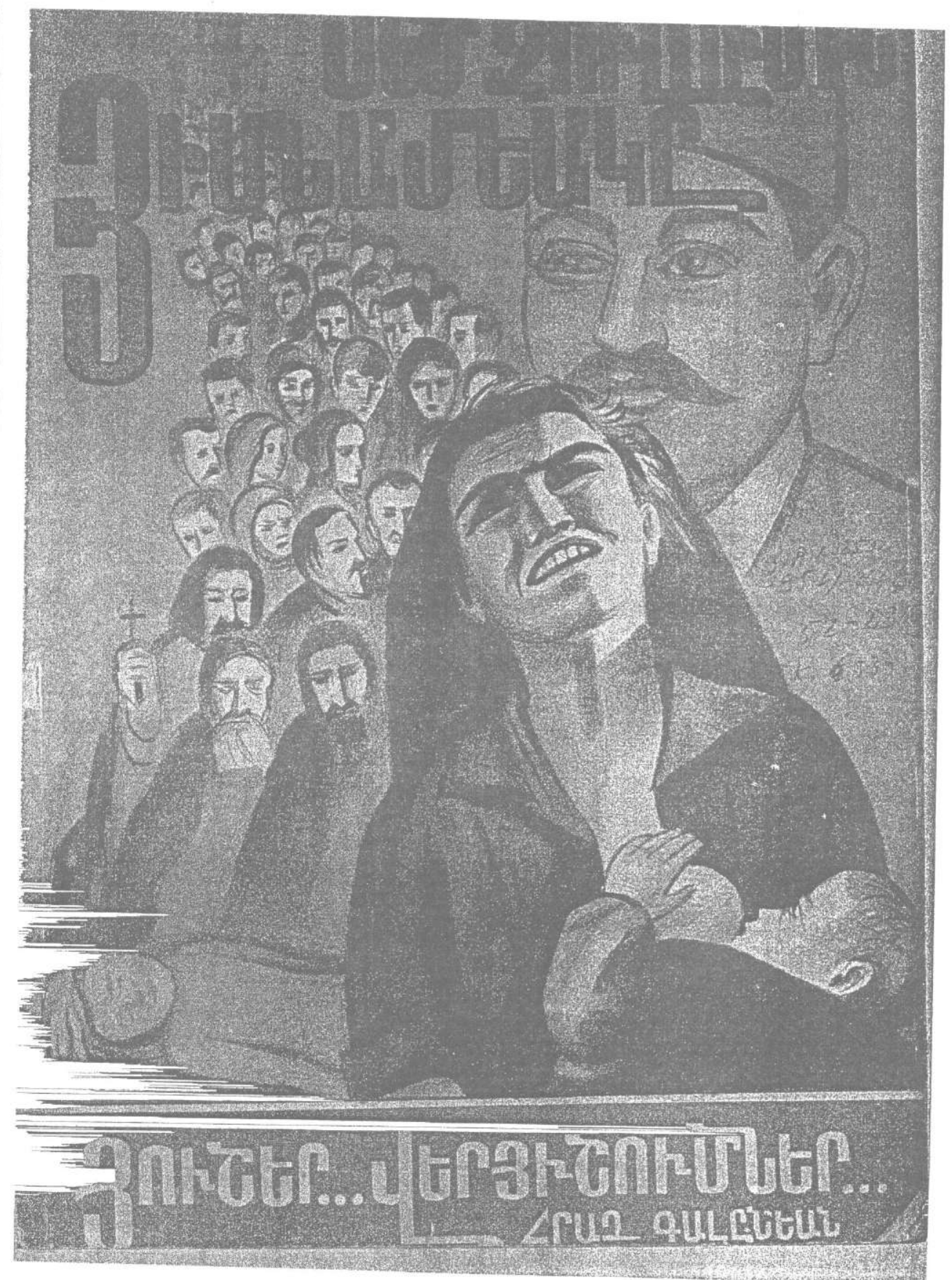




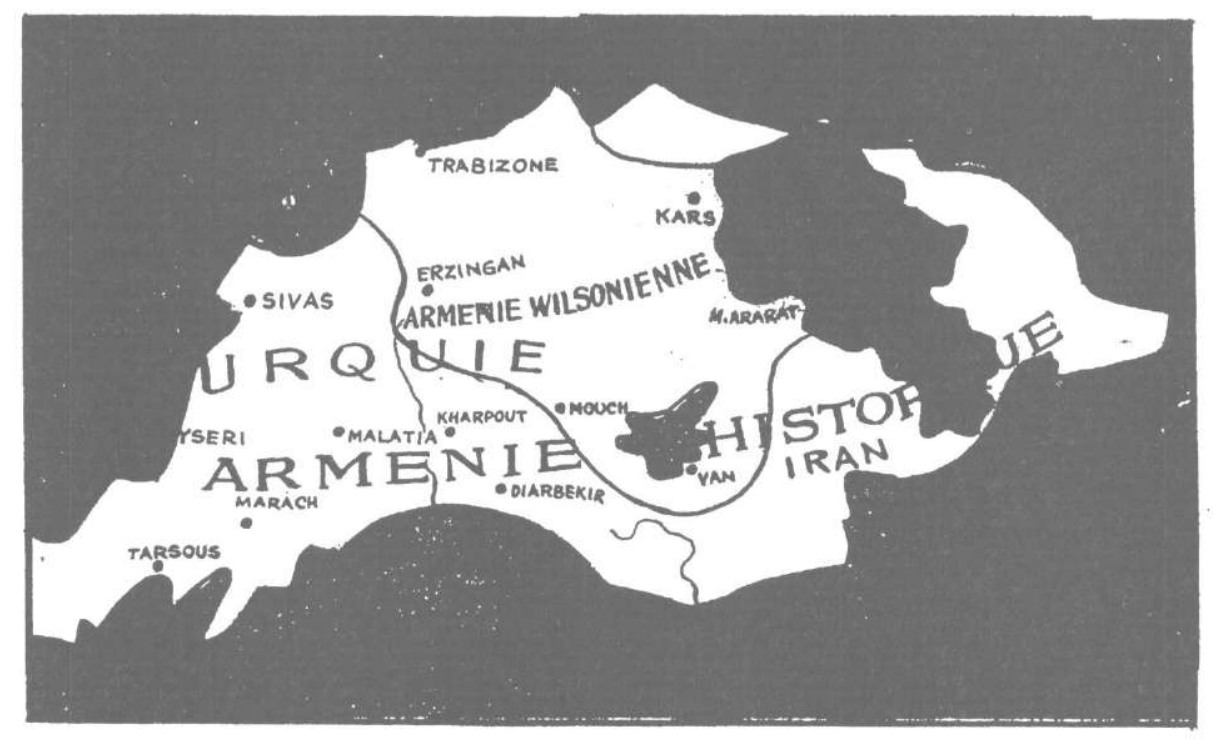

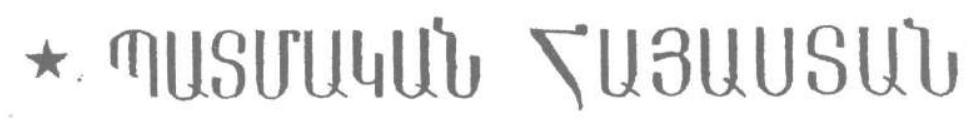

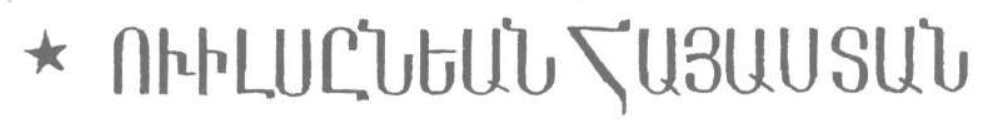

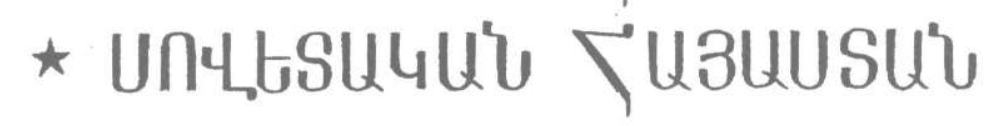


T. $c$.

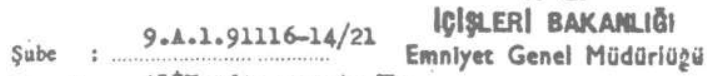

Konn ': IrtK adiz gase to Hk.

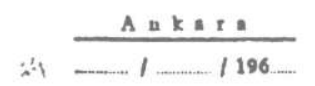

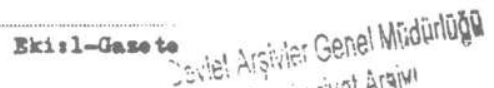

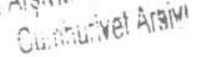

$16 ? 270$

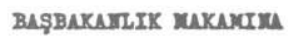

Iran'da bulunan Furk eloyhters Freond Xomitolerinin yaypn - rganz olan " LutK " adli gase to 1lig̨ikto takdin kalinmaģtzr.

thut to vasinda, Tirklerin XIV.asirda sorla Ermonistan'a yorlegerok gok giddotli bir vahgottlo Ermonileri inhs ettiklerindon baheedon ro bsollikle " Ermoni Katliamins " konu olerak olo al 2p zaman saman

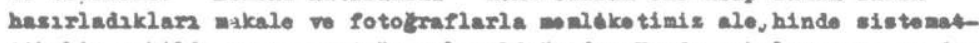

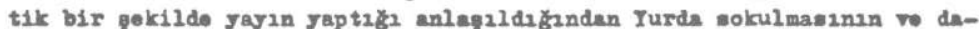

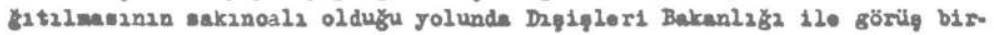
liğino rarileastix.

5680 agy2l1 Baeln Xanununun 31. maddosine göro Bakanlar Kurüun-

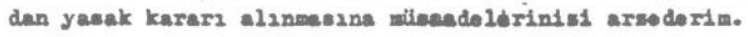

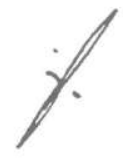

U.M.

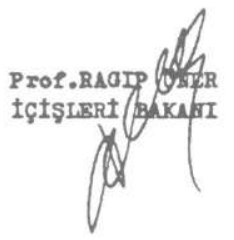

6
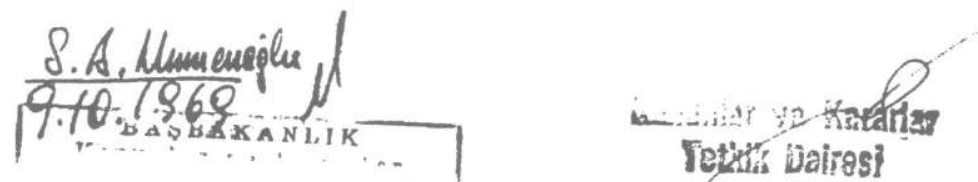

Totin' Dairgs!
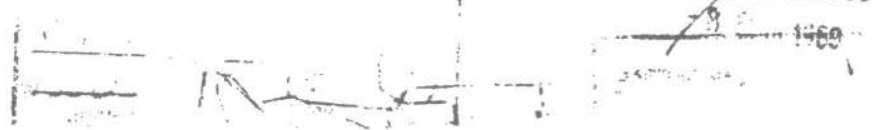


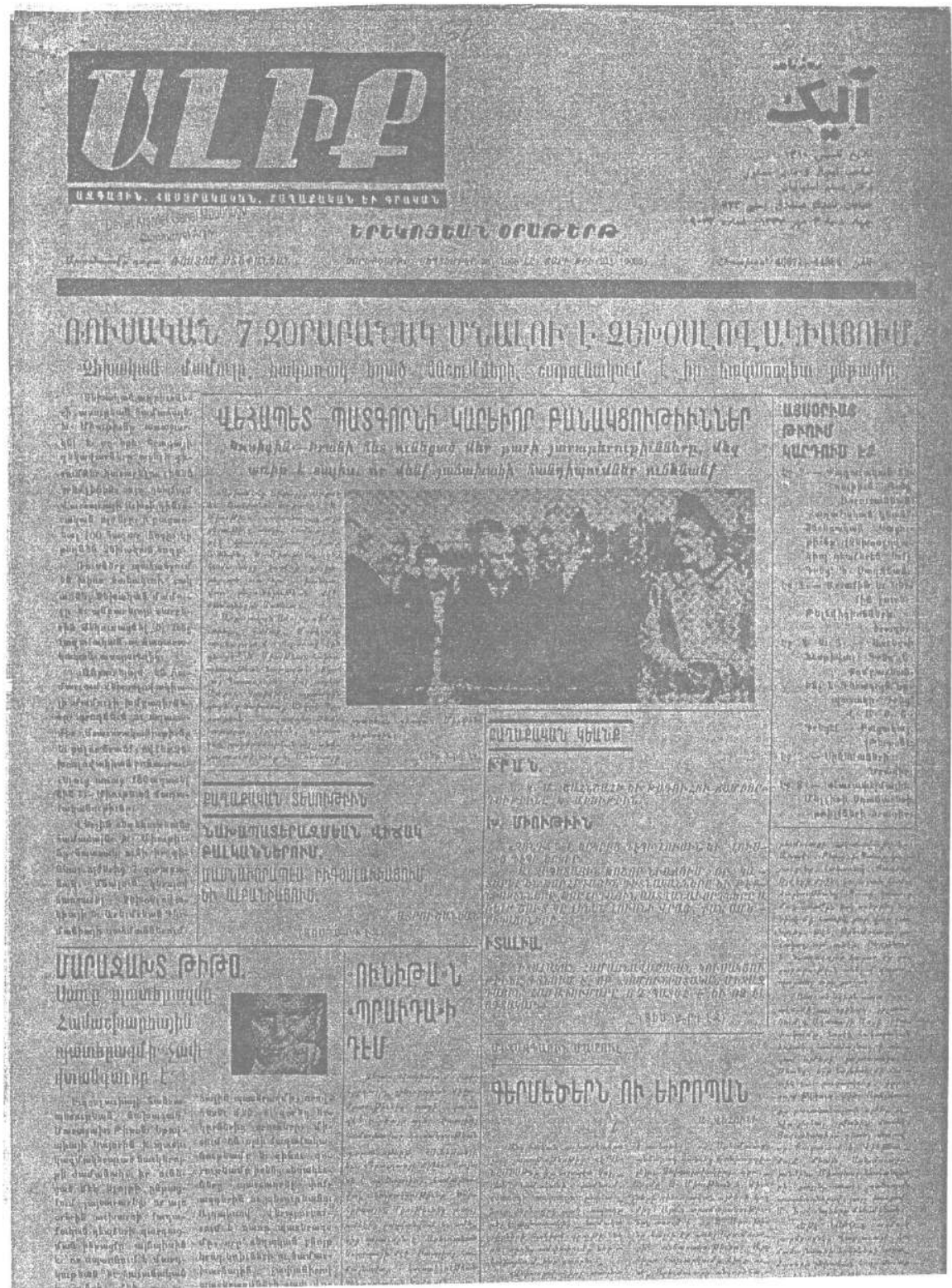


T. C.

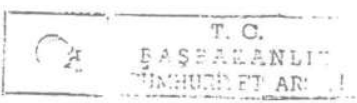

B ASB B K ANLIK

KANUNLLAR '̌E' KARARLAR

Tetkik Dairesi

Kerar Sayser

KA R A R NA M E

$\frac{6}{1360}$

Elia Kazan tarafından yazılıp New York'da, Stein And Day Ya-

yinevi tarafindan basllan (America-America) adl Ingllizce kitabın Mürkije'ye sokulmasının ve dağıtılmasının yasak edilmesi; Dışişleri Eakan-

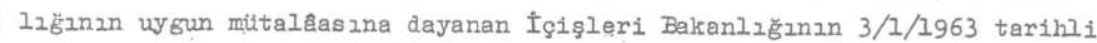
ve $91123 / 905 / 1036$ sayll yaz18 1 Uizerine,5680 sayzl1 Kanunun 31 inci maddesine göre, Bakanlar Kurulunca $1 / 2 / 1963$ terihinde kararlaştırılmıștır. tip.
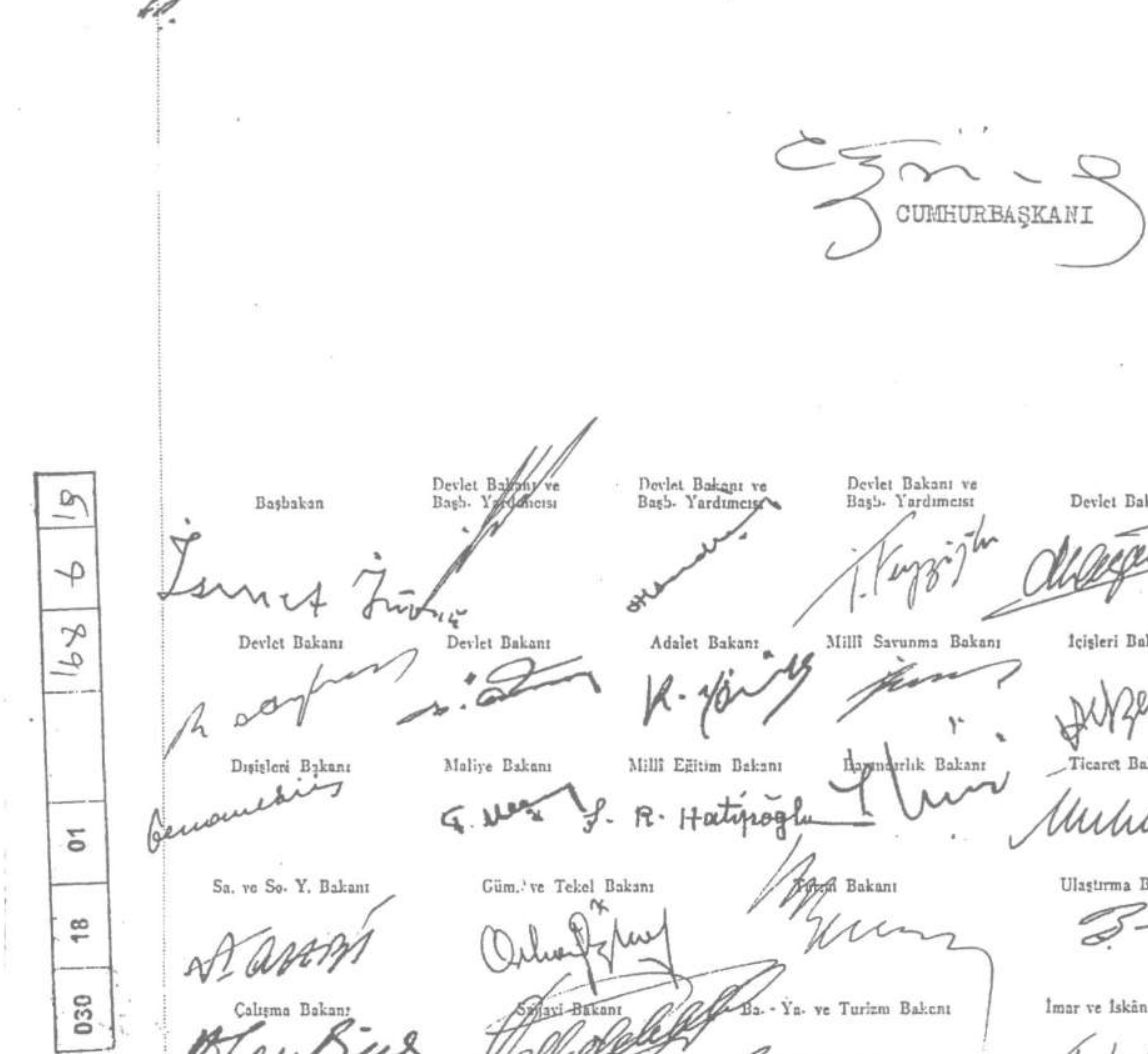

$\frac{52 / 163}{52}$
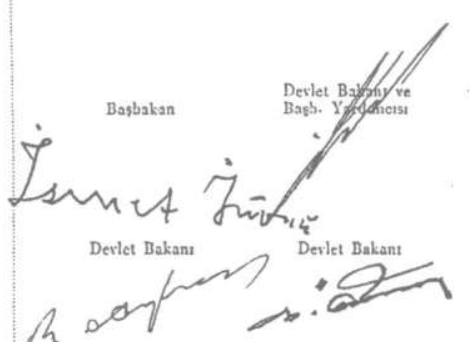

he Disiseri Bạkent

Malige Dakans

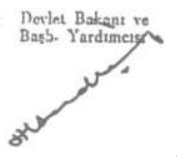

Derlet Bakant ve
Bast. Yordumess

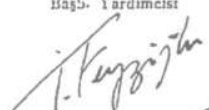

Adaiet Bakans

Millt Sarunms Bokans

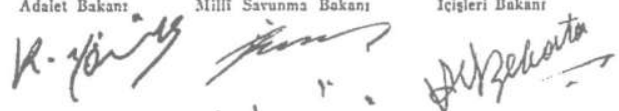

$r$.

Genome 4

4. Wers.

Milli Eäitim Dakan

Hopnfrilk Bakant

Wry

Sa. ve So. Y. Bakant

Cüm.' re Tekel Baks

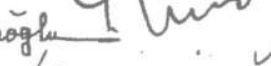

Munur te

A) Cusars

Ciluestrat

If Bakanı

Ulsgurma Bakaur

$2 ?$

olem jies

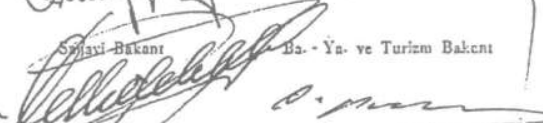

Imar ve Iskên Bakan

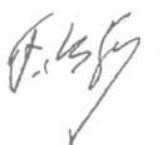




$$
-F 52
$$

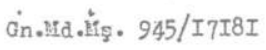

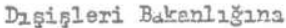

$52 \cdot 163$

$24 / I I / I 962$

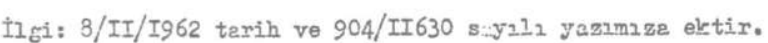

Amerika Rejisör mik Kazan' In konusu vurdunuede Eegen"Amerika Amerika" adl film senaryosu kitap helinde Amerika'daki Stein and Day Yavin evi tarafinda. yayınlanmıştır.

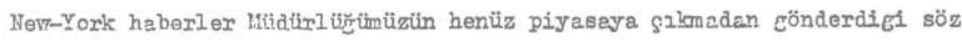
konusu kitap Genel Iüidïrl ük Hï̌şevirliğinde incelenmiģtir.

"Americe Amerioa" kitabi Merkez Fylm Komisyonunun senaryo ile il fili karir Inda yeptzğ değişiklik ve düzel tmelere itibar edilmedíği gibi komisyonun incelemesi için Kezan'In verdiği orijinal Ingilizce senaryo metninde bulunmayan birçok sahne ve diyaloglerın sonredan kitaba ilâve edildioği enlaģzlmıştır.

Yapllan bütü bu ilevelerin Tïrkleri ve Türklügil roncide edici mehiyette olması,kasten böyle bir yola tevessil edildiği intibaznz da vermaktedir.

Icinde yer yer tarihs hakiketlerin tehrif edildiŏi bu kitabe, Amerika ileri gelen san'at ve politika adamlaranın önsöz ve kitep hakkandaki kanaatleri de elklenmistir.

Kieselâ: S.M.Behram ;

"Kilisenin Türk askerleri tarafinden yakalması ve kilisenin 1çinde Türklerin yaptı.̌̆ vahşot ve mezalim karşısında Emenilerin yonglnden kurtamlmaları için Isa'ya yelvarışların oksurken, Polonya'da Çerlik Rusy''sınden kaçan anne ve bebenın düçar olduklam ekcibeti hatırledum" domoktedir.

J.Steinbeck "Yepyeni bir şelcilde sunulen son deroce enteresen bir oser".

R. Kennedy "Ben bunu kaleme alsnazdrm. Havret verecek derecede iyi bir GAG sözlerigle kitabı övmektecir.

Böylece"smerioa America"sahibing jurdumuzda gösterilen bütün ilei,misafirDorvarlik ve kolaylığa rağmen Türkiyc'vi ve Türleleri kötü ve janlı hislerimigi rencide eden Avrupe ve Amerike'de yavanlenmas köjii kitaplerın jeni bir örnoğini vermektadir.

Kitepta tesbit edilen Bonradan yapllm1ş ilêveler ve Uerkez Film Kontrol Konisyonunun lararlarına ayterı mahzurlu hususlar şunlardzrs

(Sahife 20'de) Kayseri'nin fethi tarihi 1074 olarak düzotilmişleen lef tepte 1381 tarihi killanzlmastir.

(Sahife 21'de) Kurban Bayram 'nan kutlanness taf'str edilirken aile reisinin kurbenz kesmeye hezllanıs ve elinde byçaklarz biledífi belirtilerek-o bundan cok ivi anlar, blçak onun hem aleti hem silahldir-donilnoktedir.

(Sahife 25,26,27'do) Tïrsk Tüizbaşısının, seçimini sağlamak için dačçan topl:

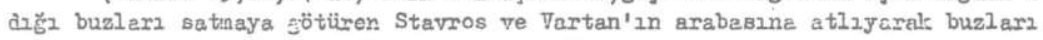
vă̈me ettiklerini ve yere döktïklerini ërrüyorug.Halbulei bu sahno Komisyonca mah zurlu görül dü̈̈̈̈nden Kazan Türl Subavınzn bus satınalnak için para vermasi üzerinc Stevros'un perayl firlatzası ve buna lazen Tïrk Subayınzn da buzlarz düktürtmesi

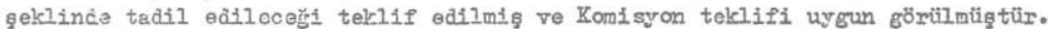

(Sahife 29'da) Frneni Vartan,kendisini Yüzbaģıya tenltzrken -Ben senin enir exindim.Senin için tavuk çaldðĕımı hatırlarsan değilmi?-demektedir.미buki orijinal senargoda tavuk hirsizllŏgna his temas edilmomistir.

(Sahife 38'de) Komlsyonca önemle izerinde durulen ldilise gckzlmass olayz

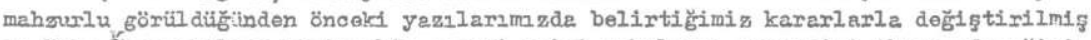
ve Elia fezan kilise yerine bir errneni evini ylkılması sahnesini 1kame edeceŏini ve buna kafi bir sahip oleruk bir hocanin Brmeniler terafindan öldürülmesi sahno sini de erliyeceğini vadetmişti.Kitapta hocanın ölïmüne temas edilmediği,eibi 


\section{(2)}

$52 \cdot 163$

bir kilise yıkılmakta, bu Tïrk askerlorine yaptımlinskte içinde yaşlısı cenci ve

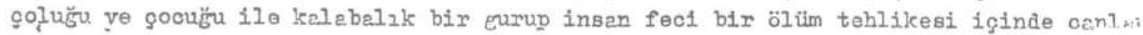
dirilmaktadır.

Bu vetmiyormus gibi bir Ermeni Türk subayznan vïzüne tijkïmekte bir begkn s1 subsyz sersip muaheze etmekte ve subay bunun üzerine ates emri vermektedir. Fu i1. velarden bagke yanglndan sonra ölen kocssım, kardeşinj veya çocuğunu celen kadinlar ra ë̈steren bir sahne eklenmig ve bu suretle bütün hiriøijgnlilk alemi adete Türkle. re kerģ isyane tahrik edilmistir.

(Schife 39'da) Gitara meyhanesinin sahibinin Tlirk oldugu ve Türkler teraf

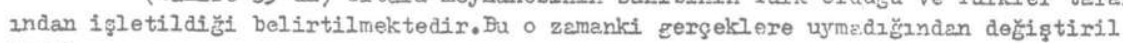
miģti.

(Sahife 39'da) Tüixlelerin Trmeni cvlerini yăgma etmesi sahnesi orijinel

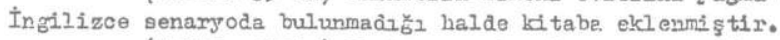

(Sahifo 40 de) Kolpisyonce incelenen senaryode mevcut olmeyan bir hapisha ne dizenlenmiş ve pislik içinde acı ile kıvrenan Stevro'ya bir asker licmesi ile vurularak "Kalk" denilmiştir.

(Sahife 43'de) Stavro'nun bebesz Isak Valinin elini ëperken Valiye rüsvei olarak pare vermekte Velinin odasunda içki içmektedir. Senaryoda boyle bir olay da yoktur.

(Sahife 45'de) Stavro'nun blivilis ennesi "Tïrkler yizlone tükübüyor, siz yağmur yă̆yor senıyorsunuz" denmektedir. Bu de sonradan eklenmightir.

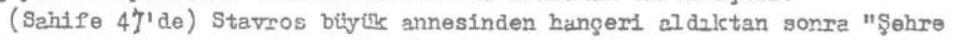

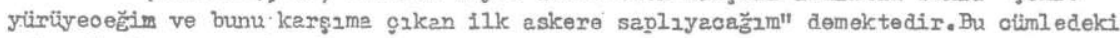
asker Komi syonce cikarılmisti.

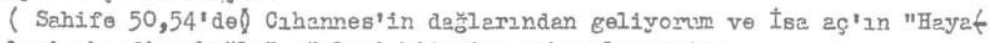
tımı Türklerin keyfine ba ̌̆l ${ }_{2}{ }^{\mathrm{n}}$ sözleri kitaptan gıkarılmemıştır.

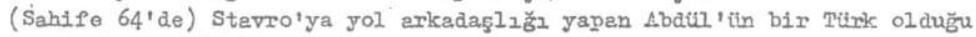

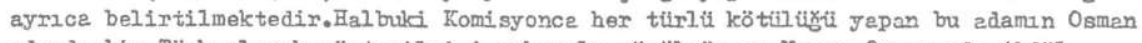
adınde bir Türk olarak eösterilimisi mahzurlu görillmüğ ve Kazen Osman adı Abdïl olarak değistirip Türk oldus̆u belirtmiyece ơini söylemiști.

(Sahife 65,66 vo 70'de) Aptỉ 'ün Türkiye'nin eşkiye ve soyernoular yctes̆1 olduĕunu belirten söglsri Komisyonce çkamldž̆ halde buna da uyulmemıştır.

fürk misafirporverlichini eöstermek iģin bir Türk evinâe Ístarro ile Abdül ï misavir eōilmeleri sahnesi atlanmıฐ̧tır.

(Sohlfe $76,79,80^{\prime} d e$ ) Senaryoda olmyen bir mahkeme sehnesi ujăurulmus pis bir odede bağdaş kurup oturen hakimin Türk olmıyen Stavro'ya heksız ve kötü muemele ettiŏi belirtilerek Aptïl 'ün halcsız olarak iktisap ettiğ Stavronun eşyaları ïs.rit...

on hakimin kendisine paylaşma teklifi yaptığ 1fade edilmekte "Nemussuz polislex" denilmoktedir.

(Sahife 81'de) Seneryode olmzyan "Biz Tïrkler basit insanlarzz,halbukd siz Rumlar medenisiniz" sözleri Abdille söyletilmektedir.

(Sahife l09'da) Genel ev iģleten bir Türk gösterilmekte ve ahlak zabltası mensuplamnzn bu evie ă̌rilanı̧̧ canlendzrılmaktadır. Sencryo metninde genel ov işlc ten bir musevi idi.

(Shhife 112'de) 0 zamanki aydunlarnn Hürriyet özlemi ile yantıklerı tonł u.

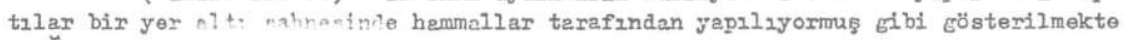
ve Garebet ad?, : Tirk milliyetçisi olarak ësterilmektodir.

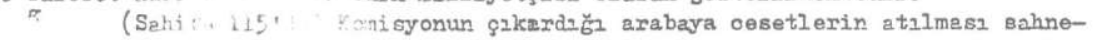
binin aymen yer slmakte ve bune cesetlerin askerler terafinden denize dökilimesi ve ölcnlerin akrabel arman matemle onlarl seyretne : nis. nnlori eiclenmelctedir.

Belirtilen hususlara zemineten, altr minerels onl tan Ahmet Camil Avosor ya diye tekdits ve bir t/1m isimler yanlıģ ifede edilmokt*, ve Stavro'nun edr bir

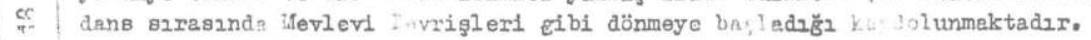


(3.)

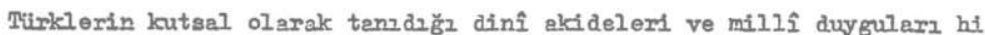
sagen,daime medarn iftiham olan Türk askerine horsizlak ve hunharlyk ve Türk adliyesine rïgvet ve iltimes ş2ibeai sürmeye yeltenen ve nihayet misafirperverliğ le ün salmaģ bir milleti soyeunou,meyhenesi ve genelevei olarak resmetmek gefletine

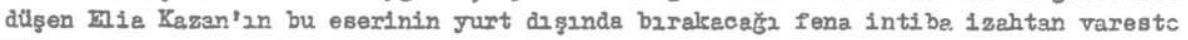
dir.

Bu hususta dostumuz ve mïtefikimiz Amerike Birleşik Devlotleri Hïkümetj nezdinde wyarma ve teşebbüllerde bulunulmasım tensiplerinize saygzlarımla arz ederim.

Suretinin eynzalr.

Baszn-Yayzn ve Turizm

$3 / 1 / 1963$ Bakam

\begin{tabular}{|l|l|l|l|l|l|l|}
\hline 030 & 18 & 01 & & 168 & 6 & 19 \\
\hline
\end{tabular}


T. C.

B ASBAKANLIK

KANUNLAR VE KARARLAR TETKKK DAIRES!

Sayn: 6/ 11087

KARARNAME

Paris'te yaymlenan (CONNAISSANCE DE L'HISTOIRE) isimli

Eki mecmuanin 15/5/1968 tarih ve 54 sayll nüshasanan 'Türkiye'ye sokulması ve dą̆ıtılimasının yasaklanması; Dışişleri Bakanlıĕınin uygun mütalassına dayanan İ̧̧işleri Bakanlığının 25/11/1968 tarih ve 1/9.A1.91116-12/126-65592 say1l yaz1s1 Üzerine, 5680 say1l1 Kanunun 31 inci maddesine göre, Bakanlar Kurulunca $9 / 12 / 1968$ tarihinde kararlaştırılmıştır.<smiles>C1C2CC12</smiles>
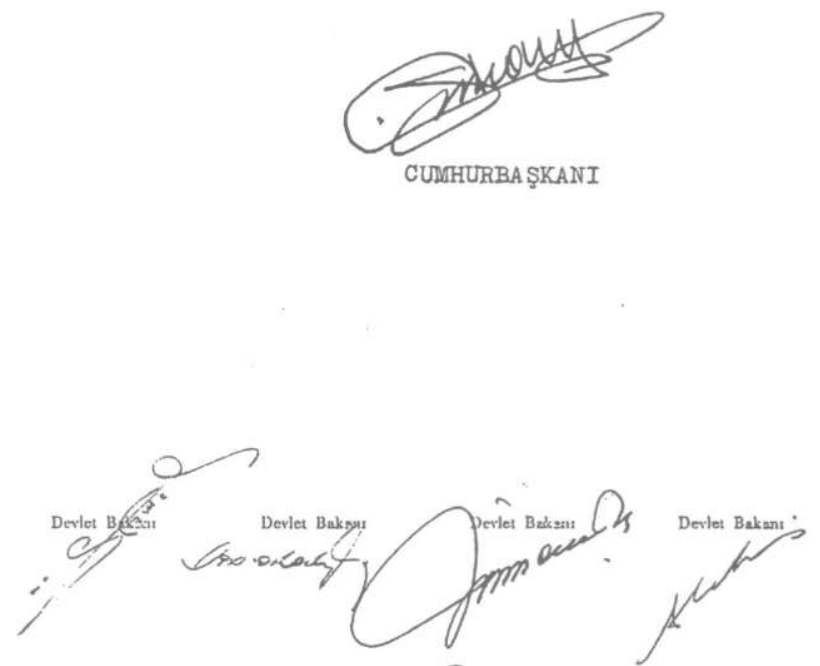

Adalet Bukany Mulli Savunina Makan
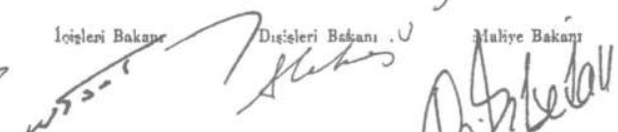

Sor

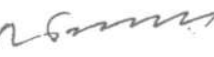

Ticaret Bakant

SaL̆, ve Sos. Y. Bskan I Güm. ve Tekel Batang
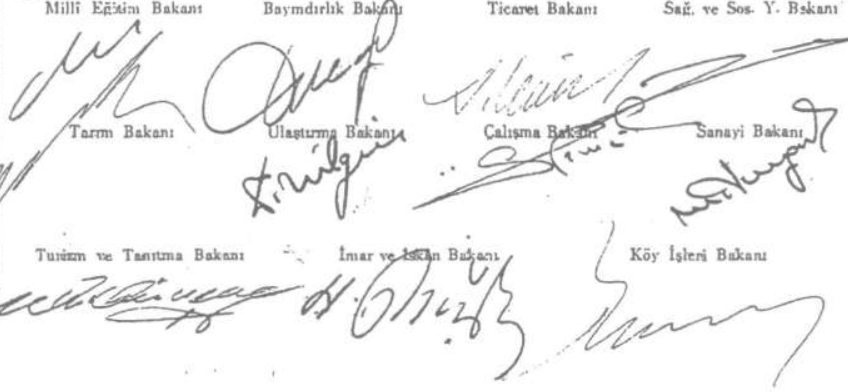

N

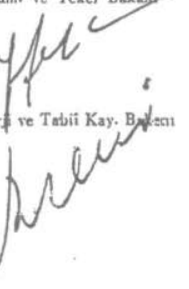
1838

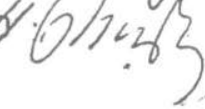




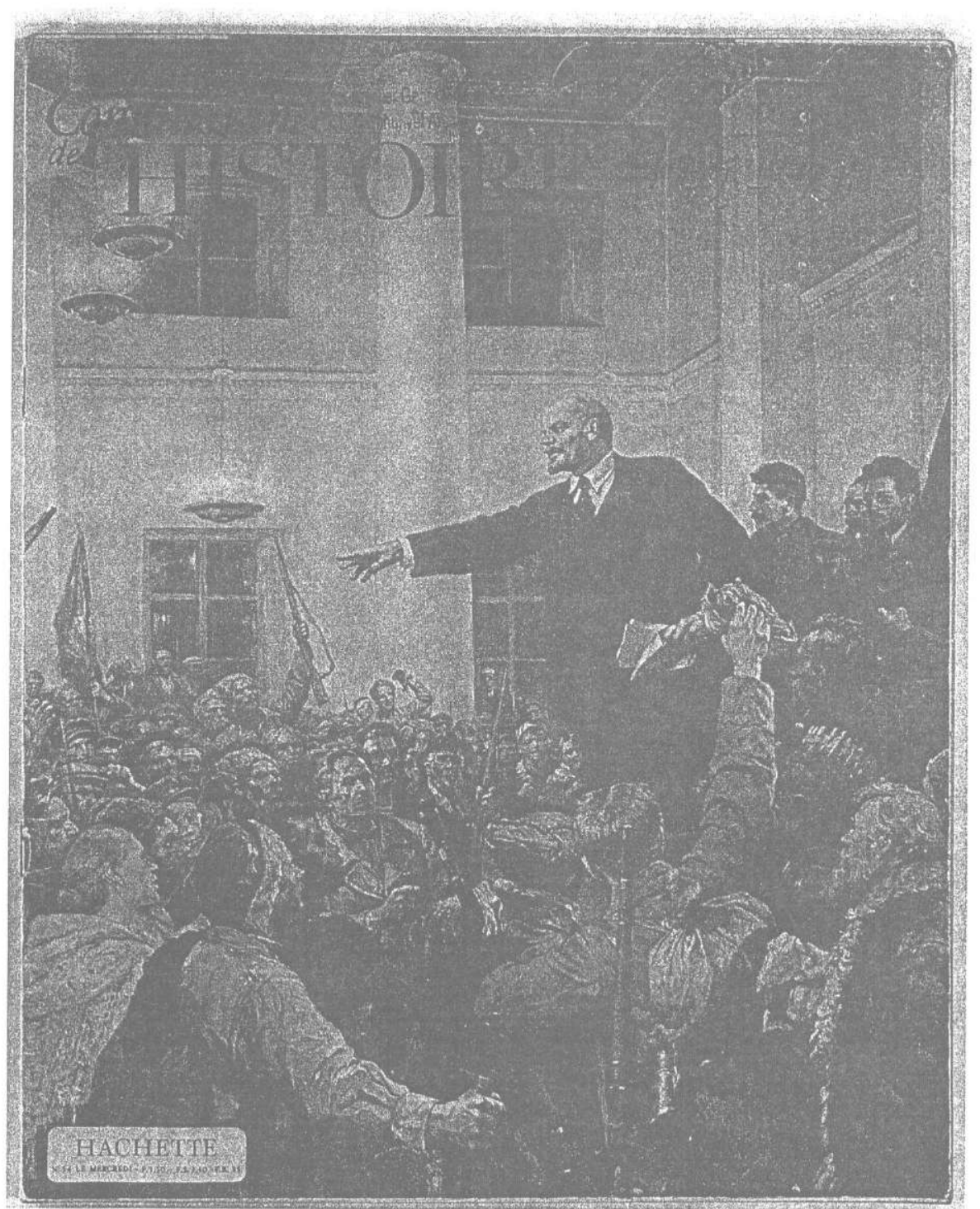


T. C.

ICISLLERI BAKARLIGI

Emnlyet Genel Múdürlüğü

Sube : 9.4.1.91116/31-116 adll kitap \#k.

Ekill-Kłtap

301

45644

Tevlet Aishigr Genei Müdüriügù

-..nit at ars
BAŞBAKANLIK MAKAMIXA

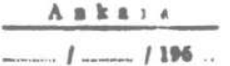
ders kitaplari yayinlama organisasyonu tarafindan 1969 yllinda Atina'da Ilkokul 5 inci sınıpları için hazırlanan "Çaร̆dą̧ Tunan Tarihı" isimli kitap iliģiktir.

Türklerin cengaver olmasına raj̄en cahil oldukları, Yunanistan'z iş̧âl ettikleri zaman Yunanlılara ait malları ellerinden alıp, kendilerini angaryalarda kullandıkları, $\theta$ rkek çocukları asker yetį̨tirmek,kız ģocukları da cariye olarak satıliak üzere alındı歺, Canavar Hüseyin Beyin Oirit'i kana buladıj 2,370 kadar kadın ve gocuŏu Melidon1 civarında bir mağarada dumanls boždư̆u,Kaşot adasını basarak bütün adalıları kılıçtan geyirdiğ jleri sürülerak Türølük aleybinde iftiralarla dolu oldugundan Yurda sokulmasanin ve dastilmasının sakıncalı olduz̆u yolunda Dışişleri Bakanlığl ile görü birlișine varılmą̧tır.

5680 sayıl2 Basın Kanununun 31.maddesine söre Bakanlar Kurulundan yasak kararı alımasına müsasdelerinizi arzederim.

Oen
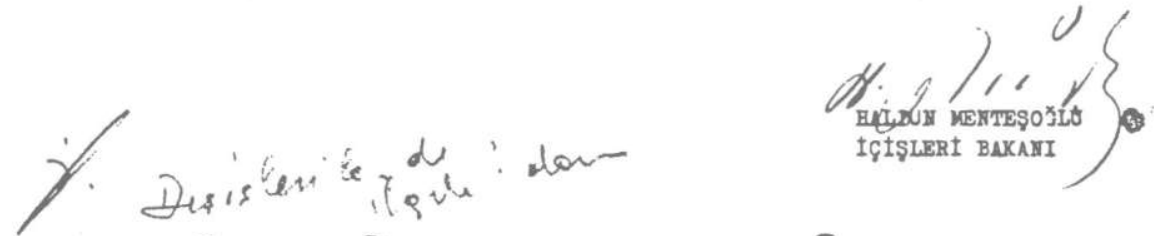

S.B.thumeuogu
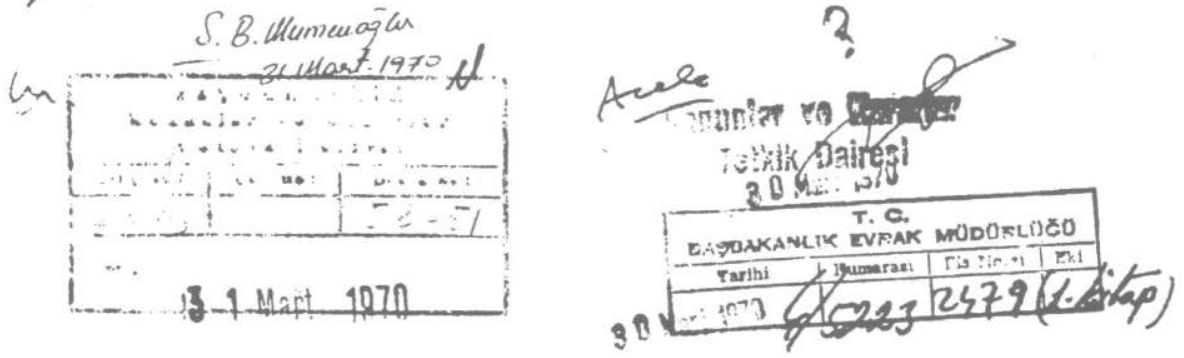
T. C.

B A S B A K A N L I K

KANUNLAR VE KARARL.AR TETKLK DAtuss!

Says : 6/ 7670

K A R A R N A M E

Londra'de basllan "Krng" adll mecmua'n In Kas Im 1966 tarihli 2 inc1 cildinin 11 inci nushasi ile. General Hasan Arfa tarafindan yazlli: Ekl 1966 yllinda Londra-Oxford Universitesi Matbaasında basilan "The Kurds" adl Ingilizce kitabın Türkiye'ye sokulmasının ve dajitllmasin n yasaklanmas 1; Içişleri Bakanllólnın 7/1/1967 tarihli ve 9.A.1-91116-13/762240,2241 sayll yazllarl Uzerine, 5680 sayll Kanunun 31.inci maddesine göre, Bakanlar Kurulunea $7 / 2$ /1967 tarihinde kararlaştırılmıştır. *<smiles>C1=CC=C1</smiles>

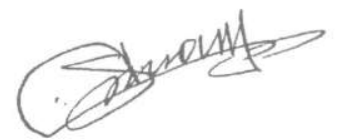

CUMTIURBASKAKI

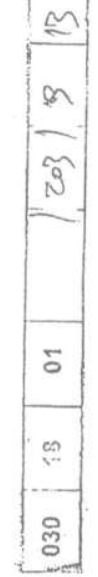

Basbakan
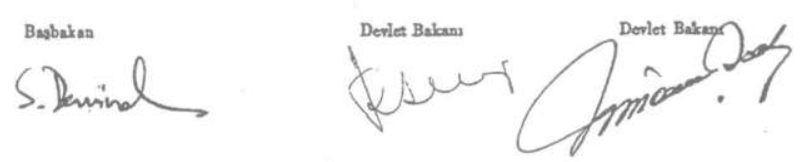

Devlet Bakans

MEill Sevunma Bakans

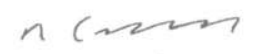

1cisleri Bakengly

man

Adalot Belawos

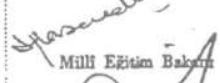

Q

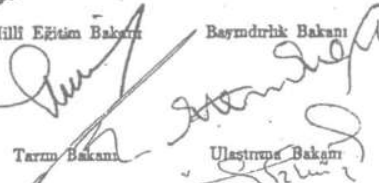

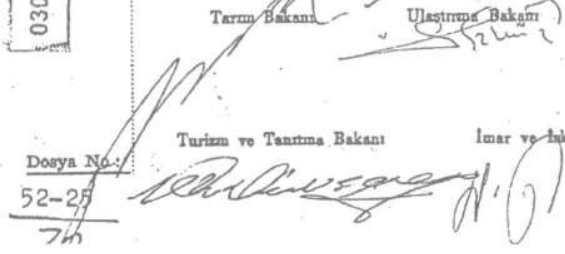

$\mathrm{N}^{\mathrm{S}}$

Dr

Disigleri Batunt Mtalige Bakapal

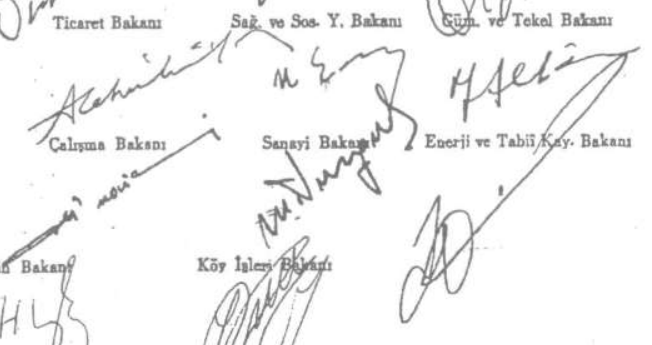




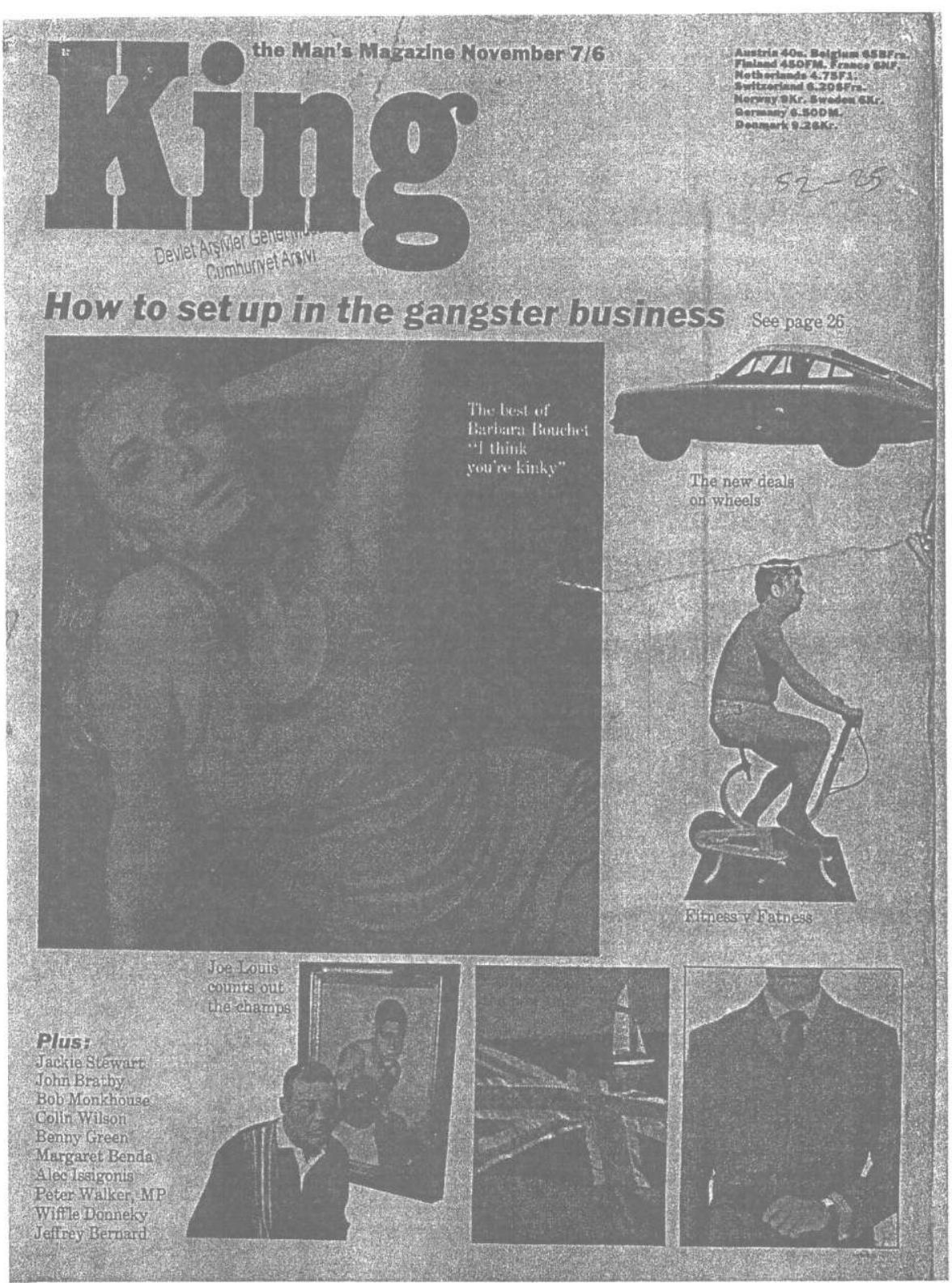




\begin{tabular}{|c|c|c|c|c|}
\hline \multirow{3}{*}{ 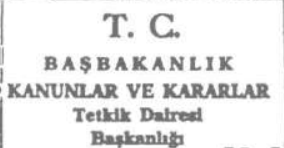 } & \multicolumn{2}{|c|}{ Yaxan memud } & \multicolumn{2}{|c|}{ TEXIT } \\
\hline & Yan tarihl: $\quad / \quad, 197$ & Gidls No: $\quad 3790$ & Edileoetk & Eathell \\
\hline & Beyax eden: $Y_{2} I_{\operatorname{man}}$ & $=$ tarihl $: 23 / 5 / 1900$ & & \\
\hline Bapkaning $52-5$ & Beyaz tarlih: $225 / 1970$ & Eklert : & & \\
\hline$\frac{\text { Karar }}{\text { Tasar }}$ No: & Karplayturanlar, & & & \\
\hline
\end{tabular}

Igiģleri Bakanlikgna

Baniyet Genel mudurlusula:

ILGI: 11/5/2970 tarih ve 9.1.1.91111/6075-1-67111 eay 212 yas2nze.

Yurt dıg̨ından getirilen Aden, Lui, to, Eecort ve Jasmin adl 5 adet mecmuanun 5660 eay 212 Tanunun 31 inci maddeaine göre Tükiye'ye okulmasz ve dä́ztilmasznin yasaklanmasna dair bulunan yaziniz ve ekleri bahis konusu mecmualar lizerinde yapilan inceleme sonucunda:

Bunlardan jasmin adl mecmuada mistehcen say llabilecek herhangi bir resme reotlanmapişt $2 x$.

Diger mecmualarin da yurt iginde basil2p satilanlarla mu-

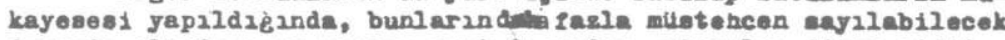
durumda olmadicl ve ayriea yurt Algindan getirilen diger ciddi mecmualar içerisinde de bu kabil resimlere yer verildibi gorlllmektedir.

Bu konudeki uygulamay bir job vermek anac $2 y l e$ bir yay nin mustehcen olup olmadiøi hususunda baģurulan kriter ile buna karar verilmesinde uygulanan usulun aczklanmasni ve llisilte sunulan bahis konusu necrualaran bir kerede bu gonden incelenerek Bonucun mutaldanizla birlikte bildirilmegini rica ederim. TP. $-\cdots$

un. T. O -

Kuni: Faik Oeansoy

Başbakna adsma wategar

bloj:

Becmua. (5 adet)

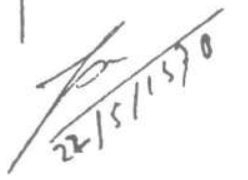


T. C.

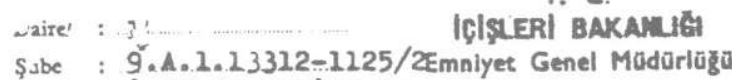

$x \rightarrow$ : ISLTCI SESI adli

broģurtun jaseklanmesi HK.

Jevit ì yer Gener Miudurlü

En1: 1-Brog̣ur

Bakanar Kurulunun 24.8.1965 tarih 6/5174 ay 121 kara-

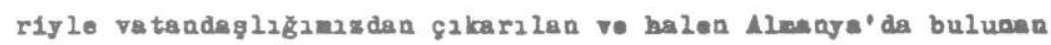

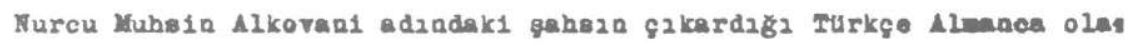

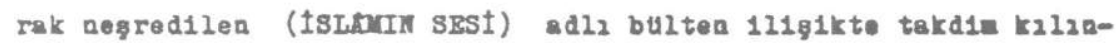
moูtır.

Içindek1 Xur'an-1 Kerim' - It gazilarda birģok yanlıg-

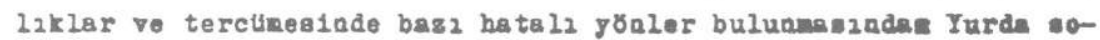

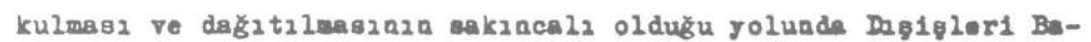

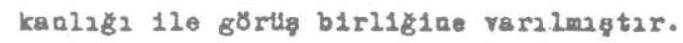

5680 eny 12 Kanunun 31. addealne grre Bakanlar Kurulundan Yagak Karari aljumasina maseadelerini arzederia.

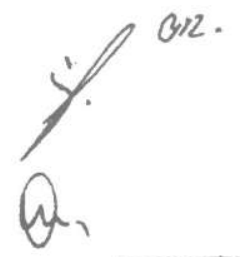

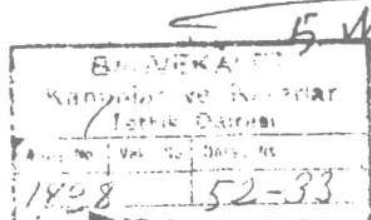
Is Mart 4968

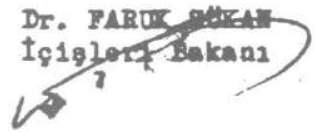

Thlar ye Rarartar

Totkil Bairesi

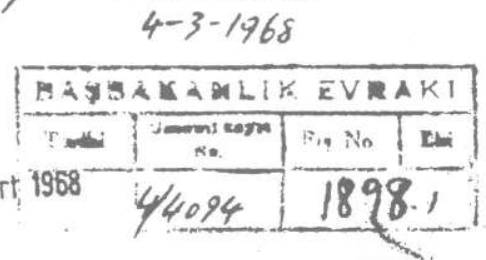




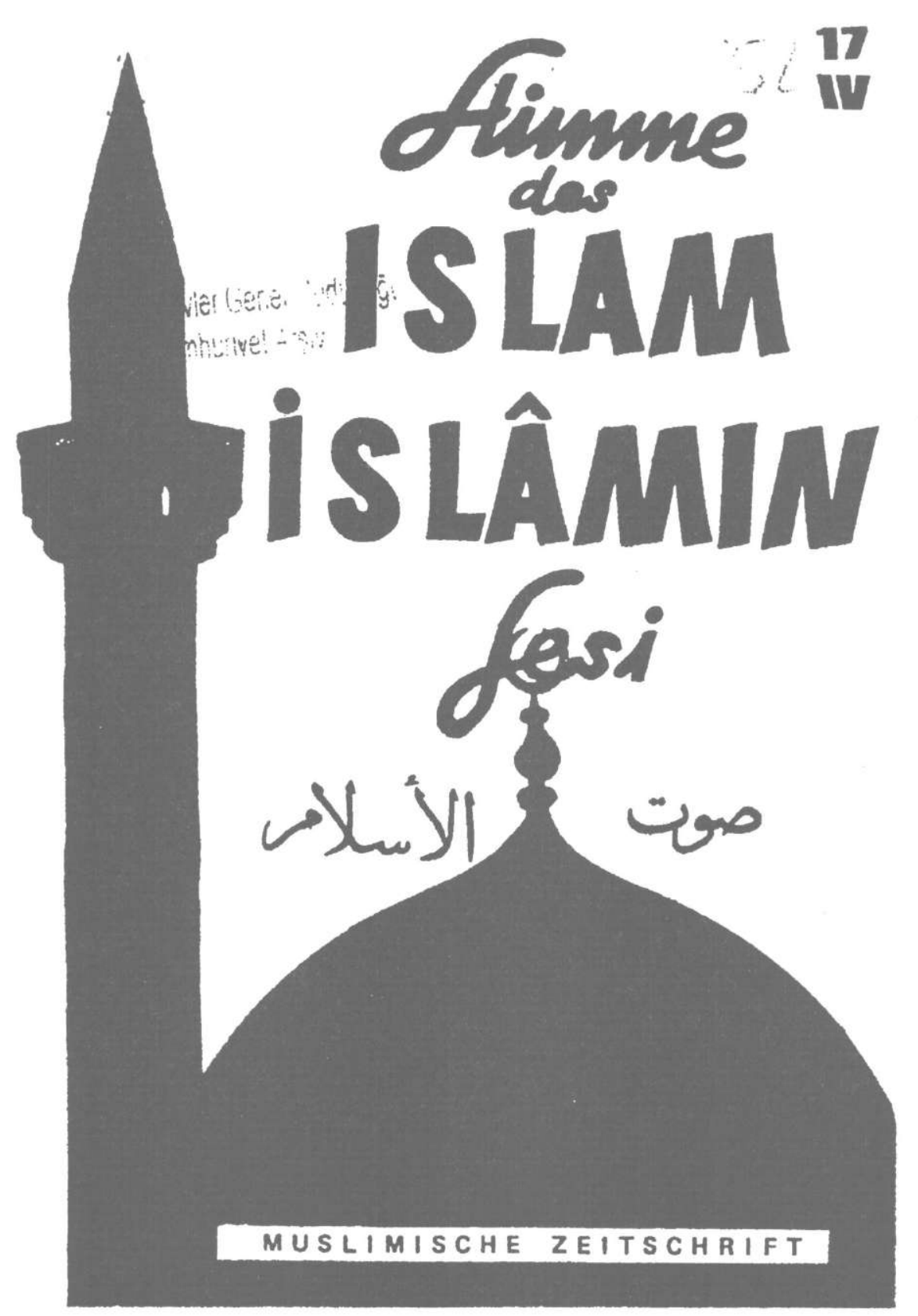




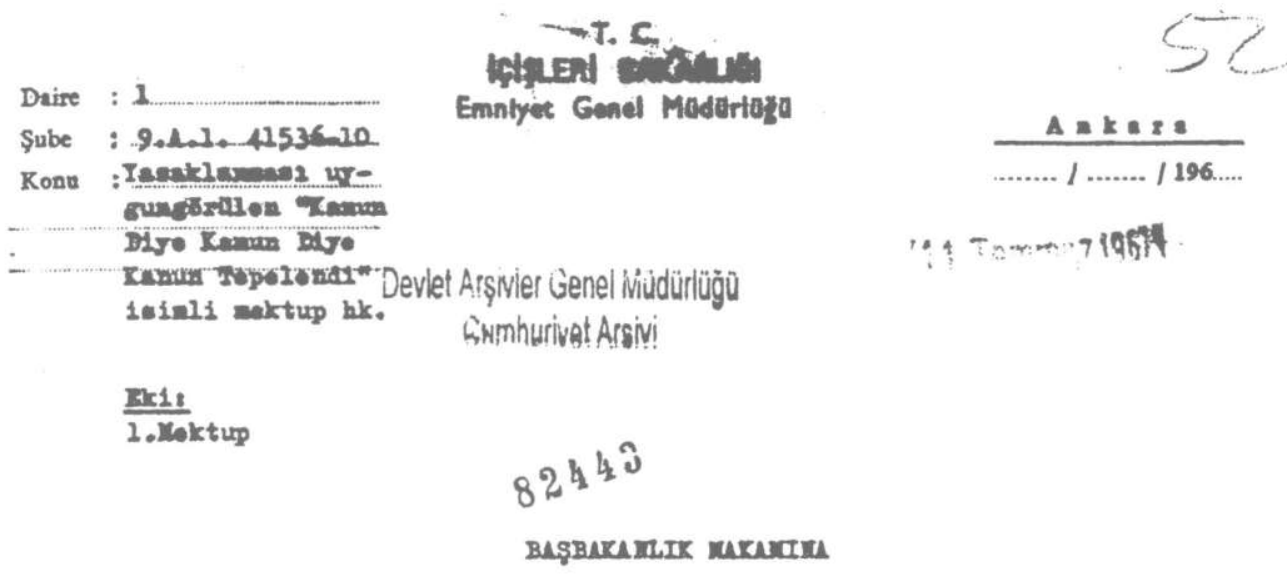

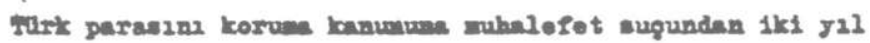

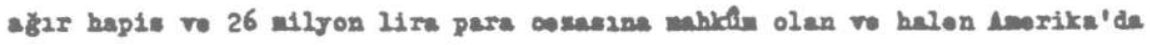

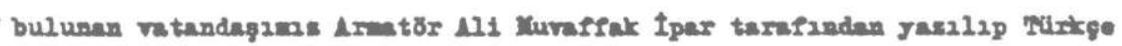

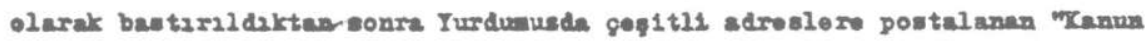

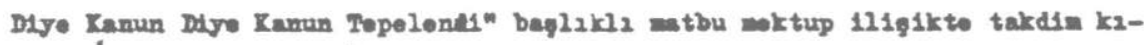
12nasg t2x.

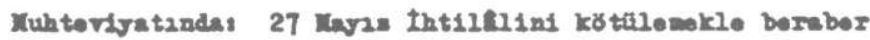

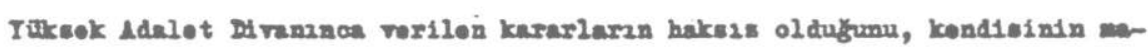

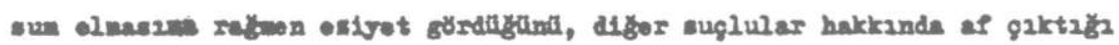

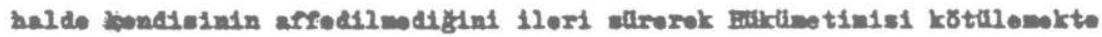

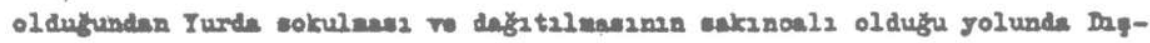

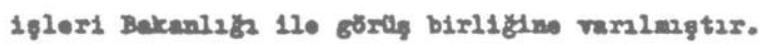

5680 anyl2 Xamuman 31. addosin forre Bakanlar Kurulun-

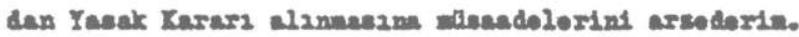

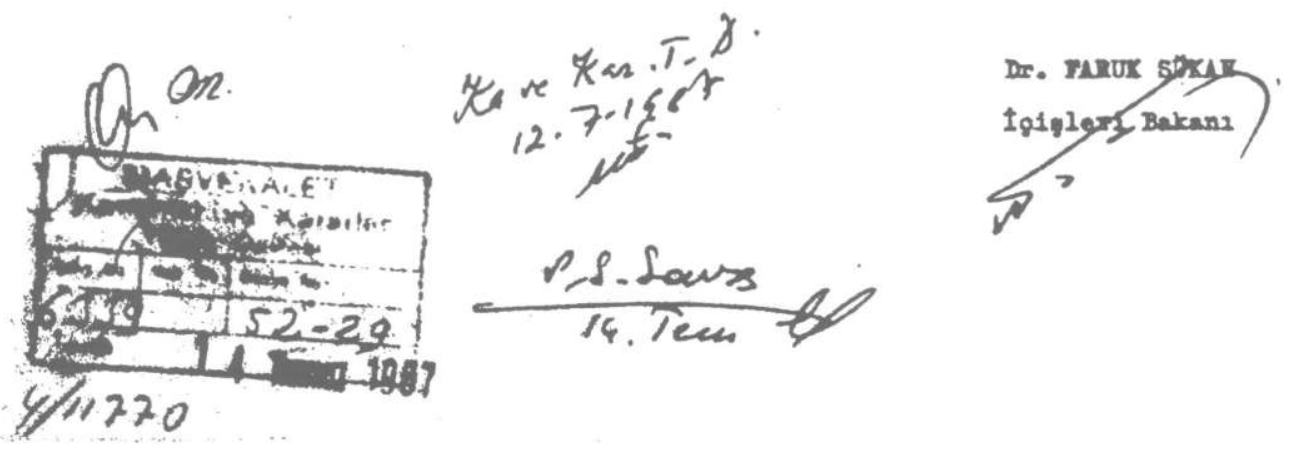




\title{
KANUN DİYE
}

\author{
KANUN DİYE
}

KANUN TEPELENDİ 


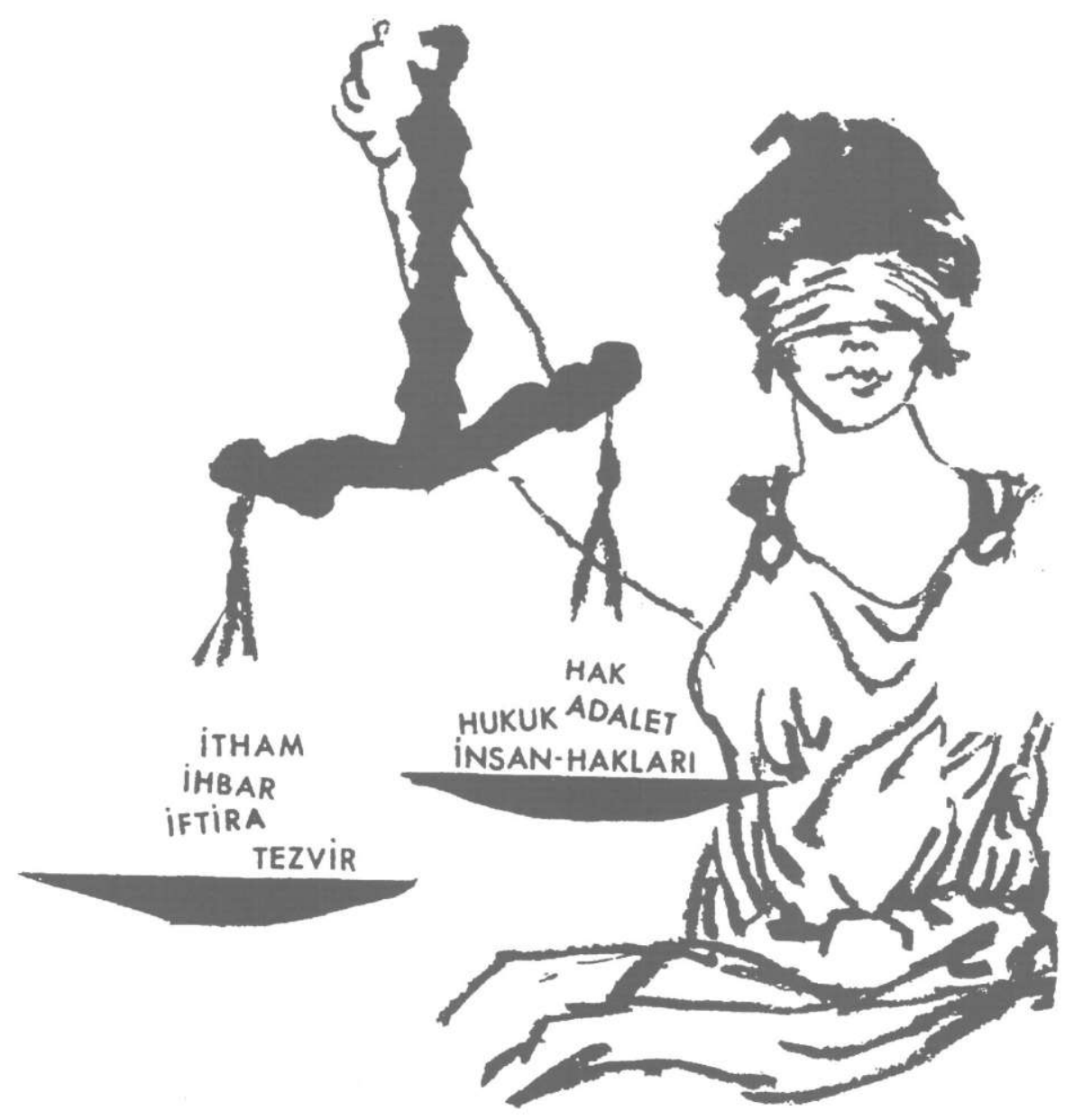


T. C.

IÇIŞLERI GAKANLIGI

Subc ,: 9.A.1.91116/.40-77 Emniyet Genel Müdürlïğö

Konu : Bl-Fotih'l1 1lgili broşürler hk.

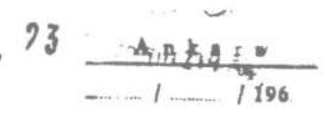

Eki \& l-Pake t

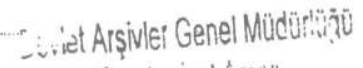

Rumhiriket irc?ll

$$
108382
$$

BAŞBAKANLIX MAKAMIYA

Israil Hükümeti tarafandan 1ągal edilen Arap topraklara-

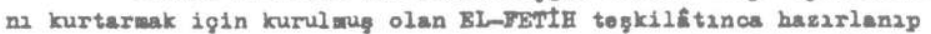

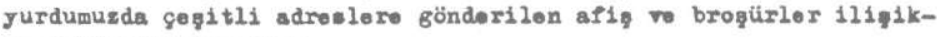
te takdia kılinmightır.

Momleketimiz ig̨in zararla propoganda rasitasi olarak kul-

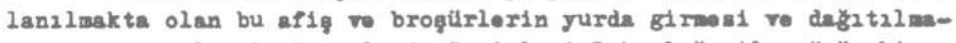

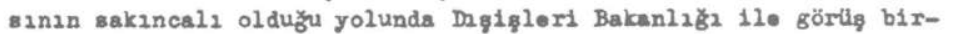
11 grine varilmig̨tir.

5680 gagla kanunun 31.Maddesine göre Bakanlar Kurulundan yasak kararı alınmasina milsadoleriniei arzoderim.
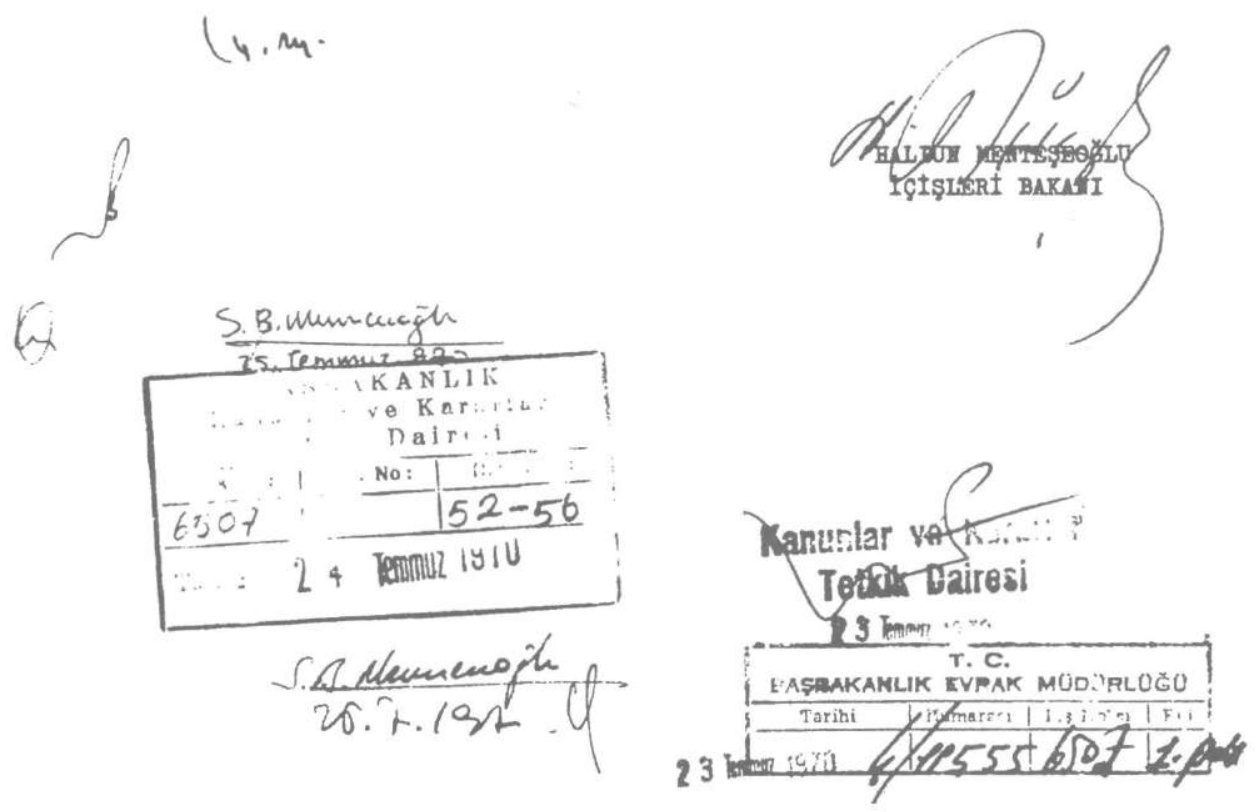


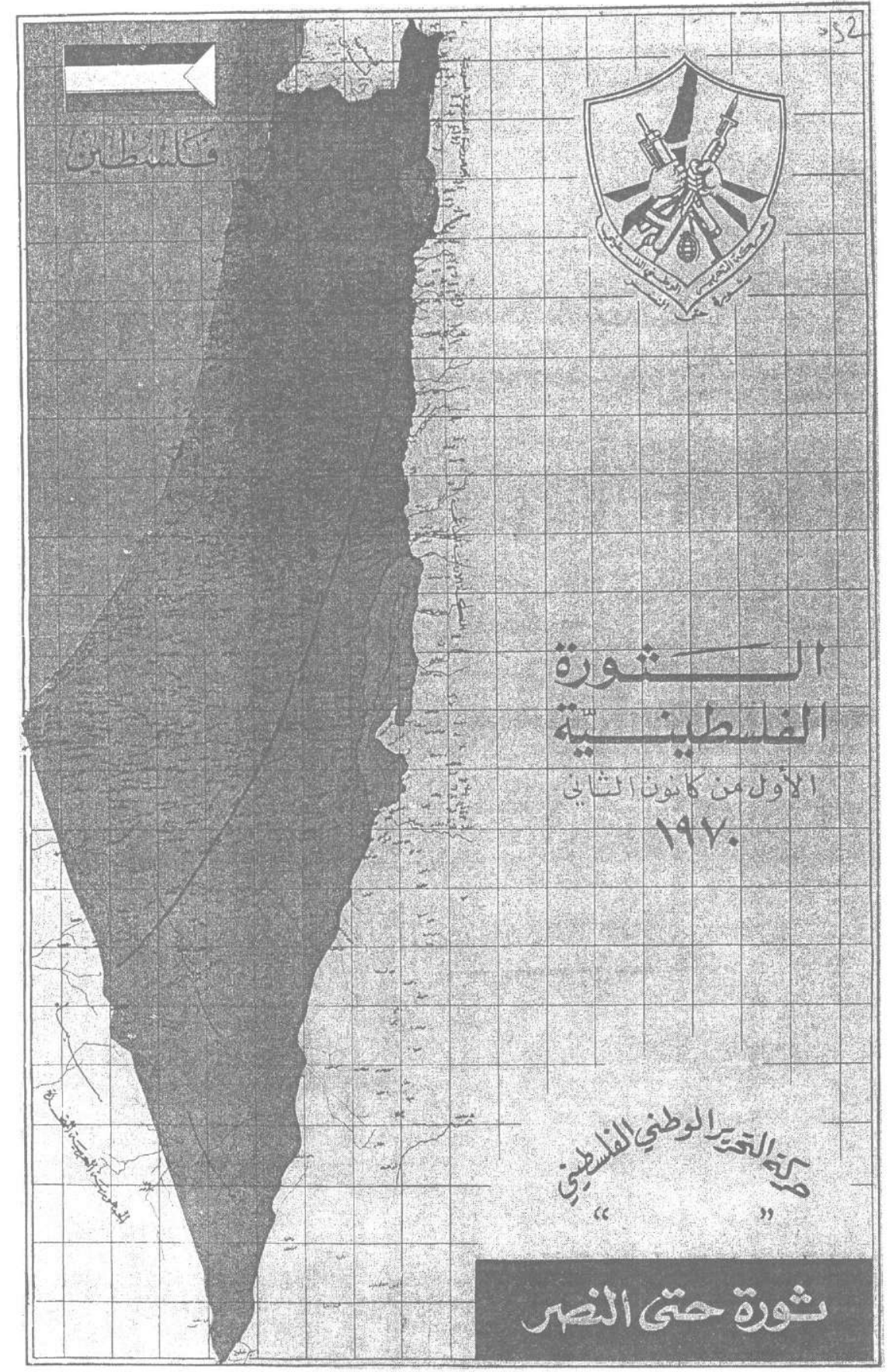

